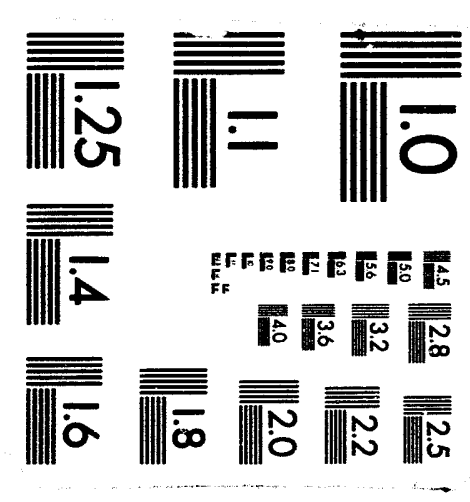



$2 / 2894850$

UCRL-ID-115618

\section{A COMPARISON OF RISKIND AND RADTRAN 4}

Gregg P. Brumburgh

H. Poter Alesso

November, 1993

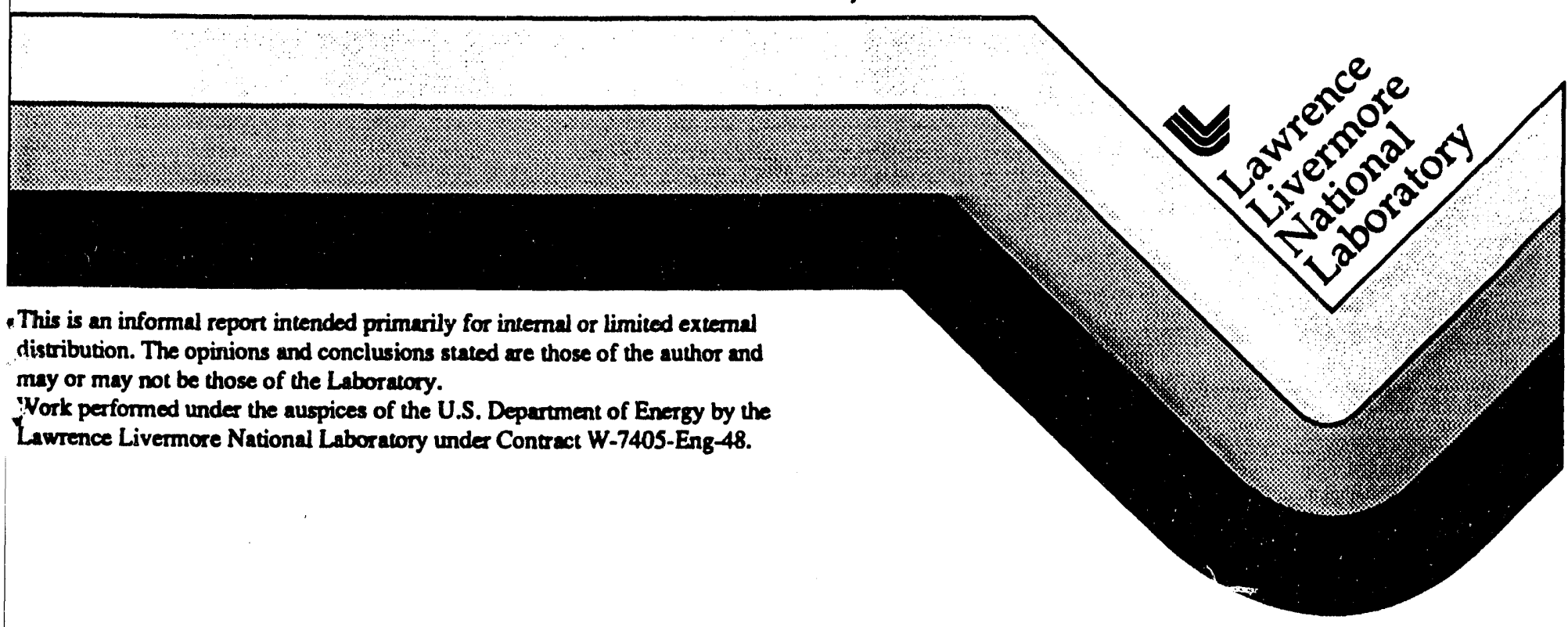




\section{DISCLAIMER}

This document was prepered ss en sceont of wort sponocred by an aseacy of the Unitted States Governineat. Neither the Unived States Government wor the Univensity of Caltformin nor any of their emplojees, makes any

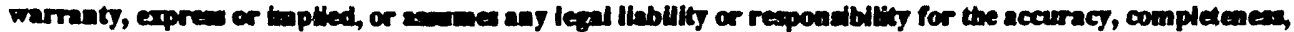

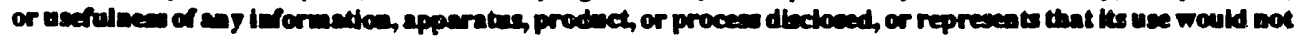

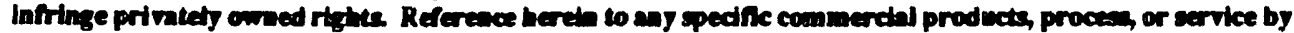

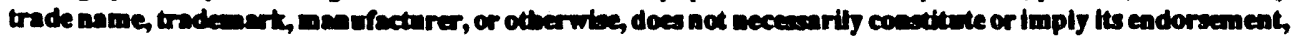

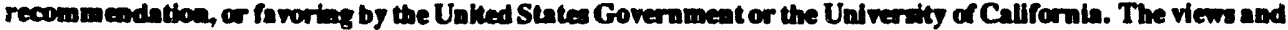
opinions of authors expresied herela to not necesartly state or reflect those of the United States Government

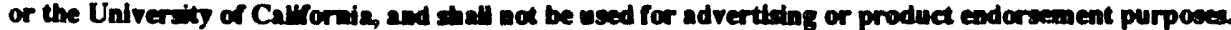

This repart has been reproduced direedy from the beet avallable copy.

Arallable to DOE and DOE coatractors from the Oritee of Sclentific and Technical Information

P.O. Box 62, Oak Rlige, TN 37831

Prices aralabie from (619) 576-8401, FTS 626-8401

Avaliable to the public trom the

Natioanl Techaical Information Service

US. Department of Commerce

5285 Port Royal Rd,

Springfield, VA 22161 


\title{
A COMPARISON OF RISKIND AND RADTRAN 4
}

\author{
Gregg P. Brumburgh \\ H. Peter Alesso \\ Lawrence Livermore National Laboratory \\ P.O. Box 808, L-196 \\ Livermore, California 94550
}

(510) 423-6758

\begin{abstract}
Our objective in this paper is to provide preliminary comparisons between the two computer codes RISKIND and RADTRAN 4. These codes have utility in evaluating radiological consequences during the transportation of radioactive materials. We reviewed the codes to three criteria: (1) the code's evaluation capability for accident sequences, frequencies, and environmental consequences, (2) the code's "user friendliness" (as well as how much specific technical expertise the user needed to apply to it), and (3) compatibility with other code output or modules.
\end{abstract}

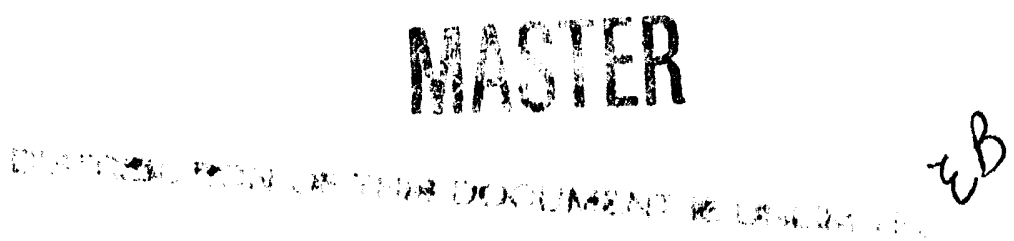




\section{A COMPARISON OF RISKIND AND RADTRAN $4^{*}$}

\section{INTRODUCTION:}

This paper provides a comparison of the two primary computer codes for calculating radiological consequences during the transportation of radioactive material: RISKIND and RADTRAN 4. A brief description of each code is provided accompanied with: a list of specific features and characteristics; positive and negative attributes; an evaluation of each code with respect to the below listed criteria; and lastly, conclusions and recommendations.

Each code was evaluated on its ability to determine, on a qualitative basis, accident risk assessment in three primary areas: accident sequences, frequencies, and environments (standard probabilistic risk assessment methodology); system response assessment; and, radioactive and hazardous material release and exposure consequences. Specifically, these areas include: the ability to interface with other codes to provide input to the main program; built-in modules; the incorporation of open architecture to facilitate the use of current and future computer programs; the ability to employ external databases in the areas of meteorology, population distributions, terrain, and accident probabilities; and finally, to ensure that either code does not exercise the "averaging" of parameters which are known to be dynamic over any accident scenario.

The scope of this comparison is limiter to subjective observation of the performance of each code acquired through the personal use of both RISKIND and RADTRAN 4 and through observations solicited from other users. Consequently, an in depth evaluation and comparison of each codes' mathematical models is not included. However, a previous review by the Argonne National Laboratory is included as Appendix` A.

\section{BACKGROUND:}

RISKIND, developed by the U.S. Department of Energy through the Argonne National Laboratory, estimates the potential radiological consequences and health risks to individuals and the collective population from exposures associated with the transportation of spent nuclear fuel. The models included in RISKIND were adapted to calculate the exposure to individuals under various incident-free and accident conditions. RISKIND is semi-interactive and can be run on an IBM (or equivalent) personal computer.

The RADTRAN 4 computer code, developed by the DoE through Sandia National Laboratory, combines user-determined meteorological, demographic, transportation, packaging, and material factors with health physics data to calculate the expected radiological consequences of incident-free transportation and accident risk of transporting radioactive material. The code is operated on DEC VAX computers at SNL, Albuquerque, New Mexico. It can either be installed on a mainframe computer or accessed by a local terminal through TRANSNET. TRANSNET is a compilation of risk, systems analysis, routing and cost models as well as related data pertaining to radioactive materials transportation. After obtaining a password, users may access TRANSNET with a personal computer and modem or through the INTERNET 132.175.129.29 address.

\footnotetext{
* Work performed under the auspices of the U.S. Department of Energy by the Lawrence Livermore National Laboratory under Contract W-7405-Eng-48.
} 


\section{II.A. RISKIND CODE FEATURES:}

The following paragraphs contain excerpts from the RISKIND Users Manual. ${ }^{1}$ A copy of one RISKIND computer run is located in Appendix B.

The incident-free models assess exposures from both gamma and neutron radiation and can account for different cask designs. Incident-free exposure considers those occurrences when the transport vehicle is at stop or in transit. Exposed individuals at a stop may include the vehicle inspector, gas station attendant, passenger at a traffic jam, and so forth; the receptors for the in-transit exposure may include the residents living adjacent to a highway and the passengers sharing the traffic link with the transport vehicle.

The accident models include accidental release, atmospheric transport, and the environmental pathways of radionuclides from spent fuels. The models are supported by databases which are specific to spent nuclear fuels and include a radionuclide inventory and dose conversion factors. The code allows for user-specified accident scenarios as well as receptor locations under various exposure conditions (including individual air and food intake rates) and meteorological conditions, thereby facilitating the estimation of radiological consequences and health risks for individuals. Median (50\% probability) and typical worst-case (less than 5\% probability of being exceeded) doses and health consequences from potential accident releases are calculated by constructing a cumulative dose/probability distribution curve for a complete matrix of site joint-wind frequency data. Under accident conditions, various scenarios were characterized according to an array of spent nuclear fuel cask responses as described in the NRC's modal study (LLNL 1987). In that study, all accidents are represented by twenty (20) discrete severity modes (i.e.., response regions). These response regions range from likely events (with minor consequences) to highly unlikely events (with severe consequences). All potential accident regions are fully represented by the 20 response regions.

The pathway model includes exposure pathways from direct external radiation from the cask (due to loss of shielding), external exposure from the radioactive cloud and ground contamination, and internal exposure from inhalation of radionuclides in the air and potential ingestion of contaminated foods and water.

Health effects to individuals are estimated in terms of chances of acute or latent fatality and in terms of genetic effects from short-term exposure during initial plume passage and long-term exposure originating from deposited radioactive materials.

The consequence model includes provisions for incorporating the consequencereduction benefits of indoor-shielding, evacuation, interdiction of contaminated foods, and other protective actions such as cleanup of contamination to comply with the EPA protective action guide levels. Consequences can be presented either deterministically (i.e.., with fixed accident parameters and weather conditions) or probabilistically (i.e.., with variable accident parameters and weather conditions).

\section{II.B. RADTRAN 4 FEATURES:}

The following paragraphs contain excerpts from the RADTRAN 4 Users Manual. 2 A copy of one RADTRAN 4 computer run is located in Appendix C.

RADTRAN 4 contains seven sets of models for incident-free and accident calculations. They consist of: the material; transportation; population distribution; health effects; accident severity and package release; meteorological dispersion; and, the economic models. The component models accept both user-supplied input data and parameter values produced from other RADTRAN 4 calculations. The incident-free module produces expected values of population dose using the first three models whereas the accident module employs all seven modules to provide expected values for accidents which result in a dispersal. 
The material model addresses the material in the packages being analyzed and their constituent radioactive isotopes. An internal library of isotope-related parameter values contain data on over 50 of the most commonly transported isotopes. The model, which incorporates both point- and line-source radioactive body emitters, permits direct analysis of multiple-package shipments made up of dissimilar packages.

The transportation model defines those properties and characteristics of the routes which influence the calculation of incident-free dose, accident consequences, and accident probabilities for 10 different transportation modes. Input data can be in aggregate form for rural, urban, and suburban population-density zones including traffic densities and accident rates. Outputs are weighted by the fractions of the total length of the route represented by each zone. Alternatively, a route may be subdivided into segments $w$ th independent, user-assigned values for population density and other routespecific parameters. This LINK option allows up to 40 separate route segments (or data aggregates) in a single run. LINK can also be used to analyze the same route segments in a variety of conditions such as daytime and nighttime population densities, rush-hour conditions, and projected future population densities.

The population distribution model conducts both off-link and on-link population calculations for either the three-zone option (aggregate densities) or the LINK option. The model considers persons in vehicles traveling in the same and opposite directions, persons in passing vehicles, persons at stops, crew members, warehouse personnel, handlers and inspectors.

The health effects model is based on the Reactor Safety Study model (NRC, 1975). The radiotoxicity of the shipped isotopes is analyzed in terms of the potential for producing early fatalities, early morbidities, latent cancer fatalities, and genetic effects. The analysis is based on the computed dose received by various organs, but the model has not been updated. Dose-conversion factors from new studies may be applied to the dose-risk values generated by RADTRAN 4 to obtain health-effects with the newer models.

The accident-severity model allows the user to divide all accidents into a maximum of 20 severity categories which are defined by the user. They are based on quantitative estimates of the forces (fire, impact, crush, and puncture) potentially applied to the package. Other abnormal environments of specific interest to the user may also be evaluated. The package-behavior model combines user-specified package-release fractions with the fraction of each isotope which becomes airborne and the fraction of the airborne isotope that is of respirable size as a consequence of a given accident environment to the package. These values are combined with the accident probabilities for each severity category, the number of packages, and the number of trips to determine expected values of release for each material in each population-density zone. Additionally, the code calculates the maximum individual in-transit dose.

The meteorological model describes the dispersal of a cloud of aerosol debris released at the site of a severe accident. Basic dispersion calculations are not performed within RADTRAN 4. Instead, the user can provide either a table of averaged timeintegrated concentration (TIC) values with corresponding downwind areas within which the TIC values are exceeded; or, fractional occurrences of Pasquill atmospheric stability categories. In this case TIC and area values are included within the code for each Pasquill category, with a characteristic wind speed. Weighted averages of the results are calculated.

The economic model involves cost outlays for monitoring, cleanup, evacuation, and long-term (or permanent) land-use denial. These economic costs are subdivided into two categories. The first of these, the basic emergency response costs, is derived from input costs for immediate response by law enforcement and emergency personnel as well as costs for restoring the use of the transport link on which the accident occurred. The second category assigns costs to the decontamination of the area surrounding the accident 
site. Costs are expressed in 1980 dollars and can be adjusted for inflation by an input economic factor.

\section{RADTRAN 4 AND RISKIND COMPARISON:}

The two codes cannot ie readily compared through a set of standard data and a baseline scenario due their diverse objectives, distinct parameters, and different mathematical models. In essence, neither code can achieve the other's circumstances nor its results. Consequently, each code was evaluated on how well it meets the above listed criteria, and not necessarily what they were designed for. The paragraphs below summarize the abilities of each code and lists its shortcomings.

\section{III.A. SPECIFIC RISKIND DEFICIENCIES:}

RISKIND is a micro-code used to calculate consequences to individuals or a specific population group. Input data consists of site-specific parameters for particular locations or receptors of individuals or population distributions. RISKIND's modeling philosophy is to provide a detailed description and mathematical solution of individual or specific scenarios with the objective of addressing the concern of risks to individuals or a local community. RISKIND's deficiencies are that it(s):

is not capable of using external databases (meteorological, population, etc....); is not capable of estimating total risk to an individual or a population along an entire shipment route;

installation program is faulty;

is user unfriendly primarily due to the incorporation of poor input error mechanisms

(i.e., it is easily frozen upon entering a wrong input value for select sections);

external file function is faulty;

does not allow input of accident frequencies (i.e.., highway, truck type etc....); has limited output summary calculational options;

documentation poorly describes user-defined input parameters, has no specific order, and lacks a legible format; and,

output uses acronyms not previously defined.

\section{III.B. SPECIFIC RADTRAN DEFICIENCIES:}

Conversely, RADTRAN 4 is a macro-code used to calculate risk aggregated over all scenarios for a route in a transportation campaign (although a route may now be subdivided into segments or "links" with independent, user-assigned values for population density and other "route-specific" parameters. Input data consists of numerous route-averaged parameters for receptors specified by uniform population distributions established by density. RADTRAN's modeling philosophy is to provide a generic description and mathematical solution of all scenarios with the objective of addressing the overall risks from a shipment route. RADTRAN's deficiencies are that it(s):

is not capable of using external databases (meteorological, population, etc....); is not capable of estimating specific risks to individuals in the vicinity of a particular segment of a route;

"route-averaged" parameters tend to yield anomalous results (i.e.., increasing shipment

distance decreases route risk);

does not look at water bodies;

does not plot; 
health effects models are out of date (old data and calculational method);

will delete work if user fails to rename output file;

cannot be used for a large cross-country route;

stoptime calculations (crew rest, meals, gas, etc...) are weak;

inserts a stoptime between every route link; and,

output is difficult to read, has no specific order, blends input data with results, and lacks a legible format.

\section{CONCLUSIONS AND RECOMMENDATIONS:}

Neither code satisfies the criteria in all three areas as outlined in the Introduction. With the advent of linking, the RADTRAN code approaches the criteria more closely. However, its tendency to average risk over an entire shipment route when risk is known to vary, limits this program for risk assessment calculations. Thus, the first improvement to RADTRAN 4 would be to eliminate this "averaging" concept and improve the minor problems in its LINK option. Conversely, the RISKIND code also produces some very good calculations which should not be ignored. The first modification to this code would be to extend its calculations over larger and more diverse accident scenarios with multiple routes. Finally, it is also conceivable, that since RISKIND is normally too specific and RADTRAN too general, toth codes can be used jointly.

\section{REFERENCES:}

1. Y.C. YUAN, S.Y.CHEN, D.J. LEPOIRE, and R. ROTHMAN, "RISKIND - A Computer Program For Calculating Radiological Consequences and Health Risks From Transportation of Spent Nuclear Fuel," ANL/EAIS, Rev. 0, Environmental Assessment and Information Sciences Division, Argonne National Laboratory, February 1993.

2. K.S. NEUHAUSER, and F.L. KANIPE, "RADTRAN 4 User Guide," Volume 3, SAND89-2370, Sandia National Laboratory, Albuquerque, New Mexico, January 1992.

3 Incls:

Appendix A - ANL RADTRAN 4 Documentation Review Appendix B - RISKIND Sample Run

Appendix C - RADTRAN 4 Sample Run 
APPENDIX A

v 
Mr. Rob Rothman

Manager, Environmental and Economics

Analysis Transportation Program Offices

Chicago Operations Office

U.S. Department of Energy

Argonne, IL 60439

Dear Rob:

We have completed our review of the RADTRAN IV documentation (four volumes in all). As you requested, I am providing our perspective and comments.

Because of time constraints, we focused on the health risk rather than the economic portion of the code. We believe that a comprehensive review of the economic model should be conducted (preferably by someone who is familiar with the subject), especially in view of the EPA's latest issuance on accident protection guides (EPA 520/1-75-001-A 1990) and the sensitivity of DOE's role in postaccident cleanup activities. Also, we have not been able to directly verify all of the new additions in RADTRAN IV. In most instances, our comments refer only to statements in the documentation (in a few cases, discrepancies were discovered when a comparison with RADTRAN IV runs was made).

Overall, we believe that the RADTRAN IV documentation is an improvement over RADTRAN III version. In particular, it provides a better description of the code, correctly states some of the limitations of its applications, and contains some useful changes. However, the following areas remain underdeveloped and need substantial improvement and attention. Detailed comments are provided in the attached sheets.

1. One of the most deficient areas in RADTRAN IV is the use of outdated health effect models (WASH-1400 1975). Current health effects models such as that developed by the NRC (NUREG/CR-4214 1988) and the National Research Council (BEIR V 1990 Report) have not been incorporated or mentioned. In view of the importance of health risk in a code such as RADTRAN, the health effects models should be most uptodate. 
2. The adequacy of the verification and validation procedures and the results, as stated in the documentation provide reason for concern. The most glaring problems are the unsubstantiated and sometimes conflicting statements. These are highlighted in the following:

a. On numerous occasions, references or bases are not provided, which means that the validity of the approaches or assumptions cannot be tracked. For example, no documentation or references are provided relative to the derivation of the neutron dose formula, and a section on neutron radiation (4.2.2?) is missing entirely.

b. Some of the models described in the document are deficient. For example, the resuspension dose is always tied to the air concentration (Eq. 81, Vol. In) such that even with deliberate cleanup, the dose cannot be reduced.

c. Several assumptions made contradict the information supplied in the same document. For instance, it is stated that the product of the gamma attenuation and buildup factor is conservatively assumed as 1 in RADTRAN IV. However, equations provided in the documentation (e.g., Eq. 45, Vol. II) clearly show that the values exceed 1 within a distance of $200 \mathrm{~m}$, which indicates that a nonconservative approach is used in RADTRAN IV.

d. DOE-recommended dose factors (DOE/EH-0070) are not used for the ground exposure pathway, Instead, a simplistic equation (Eq. 91, Vol. II) that uses summed photon energies and that can yield erroneous results is used.

e. Comparisons with other codes (including RADTRAN III) are not performed or substantiated to confirm the validity of the verification. On many occasions, "conservatism" seems the only justification for the approach, even though such conservatism is not verified. Also, it is not clear which aspects of the code have been tested.

3. The DOE interdepartmental collaboration in improving the RADTRAN code is not mentioned. In particular, OCRWM's effort (in conjunction with ANL) in developing enhanced models and databases for spent nuclear fuels is overlooked. The enhancement approach was discussed at OCRWM's TCG meeting at Salt Lake City in 1987. Such effort has also resulted in ANL's development of RADTRAN input modules. These modules are intended to enhance the route-specific (state-level) data for spent nuclear fuel analyses. We believe that it is important to acknowledge these developments, which reflect the concerted effort within the DOE community in bringing about a better code for the transportation analysis. 
June 4, 1991

4. The discussion of data needs to be expanded in the RADTRAN IV documentation. Currently, the users are burdened with the task of cata collection. However, no in-depth guidance is provided as to the availability and significance of data to the code. Because the majority of users (especially novices) may not be familiar with the code, the lack of guidance on data makes the code very difficult to apply to specific situations. For example, the distinctive characteristics of the waste packages (LIW, HLW, TRU, and spent furels) have not been discussed, and their relative importance to the input data (and to the data sources) is not known. In the event that data are lacking (e. g., the ingestion transfer factor is available for only a handful of radionuclides), users are not informed or cautioned. Further, because of the assumption that all releases are at ground level (for the reason of conservatism), a distinction cannot be made between an airplane crash and a truck accident, given the same amount of release. The documentation correctly points out that having an accurate data of set is crucial to the success of RADTRAN IV runs. Therefore, users should have better guidance on the availability and selection of data parameters.

5. Many subjects discussed in one volume are sometimes repeated or elaborated in other volumes, but they are not cross-referenced. To enable readers to locate the appropriate sections, a cross-referencing system is needed. This is particularly important in Vol. I, Executive Summary, where a lot of commitments are made).

The above summarizes our comments on RADTRAN IV. If you have any questions, I can be reached at FTS 972-7695.

cc: L.J. Habegger

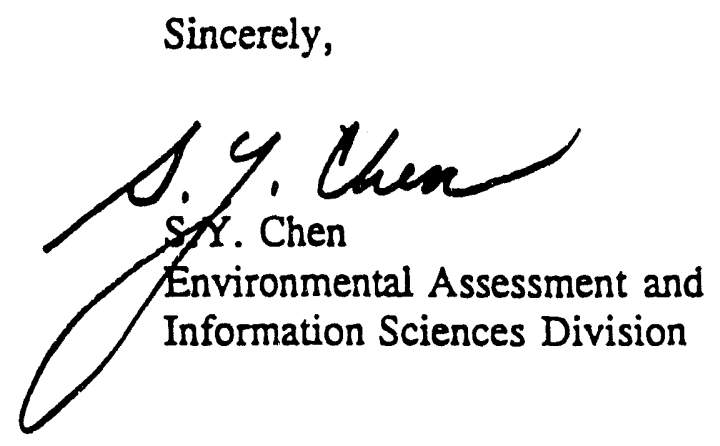

M. Conroy (DOE/HQ)

J. Roberts (DOE/CH) 


\section{Comments on Vol. I RADTRAN IV Executive Summary}

\section{General Comments}

1. The summary acknowledges the difficulties and importance of obtaining good data for the calculation, but it does not provide an in-depth discussion of the applicability of currently available data to the code. In particular, the ongoing joint effort of SNL, ANL, and $\mathrm{DOE} / \mathrm{CH}$ in developing RADTPAN enhancement data modules is not acknowledged.

2. Several current developments in health effects, dose factors, and regulatory requirements have not been incorporated into RADTRAN IV. These include the NRC health effects model (NUREG/CR-4214 1989), the health effects factors of the BEIR V Report (National Research Council 1990), and the EPA's Protection Action Guides for accidents (EPA520/175-001-A 1990).

3. The users are instructed to bear the responsibility of entering accurate and reliable data. The RADTRAN IV documentation, however, does not provide any guidance or references for obtaining accurate data. Because input data are extremely important to the outcome of results, the code would be rather useless if the users are not given adequate information on data.

4. The verification and validation procedures that are discussed in RADTRAN IV are rather weak. Comparison with one code (TREC II, for which no reference is provided) is mentioned, and yet there is no documentation to support the results and validity of the comparison. Also, the neutron component is said to be incorporated into the code; however, the entire algorithm of the neutron dose is missing.

5. Cleanup criteria and their relative importance to either the dose or cost estimation are not mentioned. This oversight should be corrected particularly in view of the publication of EPA's Protection Action Guides for nuclear accidents (EPA 1990).

\section{Specific Comments}

1. p. 2, par. 1 .

NRC 1976 and 1977 are not "regulations that govern health and safety standards." Rather, they are merely the EISs for transportation.

2. p. 2, par. 3 .

The discussion of radioactivity should also include neutrons and should address the characteristics of the radiations associated with different packages. For example, while gammas may be a primary concem for LLW, an additional concern for neutrons would apply to spent fuels or HLW. 
3. p. 2, last par.

To describe all the packages as "discrete or line source" is premature. For large packages (particularly at short distances) package representation has to be better than a point or line source to avoid being nonconservative.

4. p. 3, Fig. 2-1.

A number of pathways, such as surface water, fish or seafood, groundwater, etc. have not been specifically addressed in the RADTRAN IV code. These pathways should either be described in detail in the documentation, or Fig. 2-1, should be modified to reflect only the pathways that are considered in RADTRAN IV.

5. p. 4 , par. 1 .

The sentence "The radiation emitted during spontaneous fission ..extemal hazard, but...by individual radioisotopes...via both extemal and internal exposure" is misleading. External and internal exposures should not be distinguished this way. A better description should be provided.

6. p. 4 , par. 2 .

It should be pointed out that RADTRAN IV assumes regulatory limits if the input time-integrated (TI) values exceed the limits. Differences in regulations regarding regular shipment and exclusive-use shipment should be pointed out.

7. p. 5, Fig. 2-2.

Fig. 2-2 is difficult to understand, no explanation is given in the text to interpret the figure. For instance, what do "primary" or "secondary" mean?

8. p. 7, Fig. 3-1.

Because accident probabilities have been factored into the calculations, it is more correct to say that RADTRAN calculates "dose risks" rather than just "dose" from accidents.

9. p. 8, last par.

The expanded severity category appears to have Leen derived from the NRC Modal Study, and yet there is no reference provided (in particular, for the spent nuclear fuels) for the study.

10. p. 9, Fig. 3-2.

Fig. $3-2$ is illegible; a better figure should be provided. 
11. p. 15 , par. 2 .

It is difficult to understand the sentence, "Because of the accuracy of the input data is of reduced importance...." This sounds like an excuse for not providing users with better data.

12. p. 11, par. 2 .

This paragraph states that RADTRAN IV can compute "expected accidents for all shipments by accident severity category." However, it seems that the user enters such information and that it is not "computed" by the code.

13. p. 15 , last par.

The authors acknowledge that the accuracy of the transportation risk estimate is limited by the absence of detailed, consistent, and reliable data. However, they make a minimal effort to discuss the data availability and instead, opted for the "conservative approach." Indeed, several developments, including the joint effort with ANL in developing the state-level data (as directed by $\mathrm{DOE} / \mathrm{CH}$ ), are not acknowledged.

14. p. 22, last par.

This paragraph states that RADTRAN IV has the capability of separately analyzing neutron and gamma doses. It is not clear from the documentation whether this is the case. A RADTRAN IV test run differences in population doses but not in maximum individual doses. Some explanation is needed.

15. p. 24, Tables 4-2, and 4-3.

In looking at ine comparison tables, the changes to RADTRAN IV seem insignificant in light of the changes to RADTRAN III. Some important changes, such as the acute health effects model, the incorporation of neutron doses (neutron doses have not actually been incorporated in RADTRAN IV), and route-specific databases to go along with route-specific analytic capabilities are missing.

16. p. 26, par. 1 .

It is not true that ANL's review of RADTRAN III is undocumented. Indeed, the enhancement effort (on the state-level data) was presented at DOE's TCG meeting at Salt Lake City in 1987.

17. p. 26 , par. 3 .

Section 3.6 states that one of the limitations of RADTRAN is that it is not applicable to site-specific situations, and yet this paragraph states that the code has been used for INEL on-site transport. What is the justification for this? 
18. p. 28, par. 2.

This paragraph states that results of RADTRAN have been compared to the TREC II code, and yet no references or discussions are provided for either the TREC II code or documentation of the comparison. The verification procedure here appears to be very weak. This paragraph also states that the two codes produce the "same answers," which is difficult to believe, unless the two codes have the same algorithm. On p. 29, par. 3, TREC II does not model several pathways, including the incident-free calculations.

19. p. 28 , par. 4 .

This paragraph states that "To maintain state-of-the-art capability, the code's equations are modified when improved information becomes available...." This however, is, not the case for RADTRAN IV. For example, the NRC health model (NUREG/CR-4212) was published in 1989, and yet RADTRAN IV still uses the WASH-1400 model of 1975 for health effects. For chronic helith effects, the results of the BEIR V Report ( National Research Council 1990) also have not been incorporated.

20. p. 28 , par. 4 .

This paragraph states that the validation of RADTRAN IV is to "accurately represent the processes they are intended to replicate." However, the ensuing discussion is primarily dedicated to justifying use of the conservative i.e., the (mostly simplistic) approach. As stated in comment no. 2 in our cover letter, some of the approaches, such as the assumption that the product of the attenuation and buildup factor is 1 , are conservative and the doses (this can be shown by using the equations provided in the RADTRAN IV documentation.)

21. p. 29 , par. 2 of Sec. 5.3 .

The MACCS Code was designed to perform severe reactor consequence analyses. Its purpose, input requirements, and methodology are substantially different from those for a relatively small-scale transportation accident. Quoting MACCS may mislead the public in believing that a transportation accident is as bad as a severe reactor accident; this would be most unfortunate.

22. p. 36.

It is not clear why early morbidity should be included in the terms, because fatality is the concern of interest (consistent with latent cancer fatalities). Also, some of the terms are not defined conventionally. Appropriate technical references should be used. For example, under the definition of neutron radiation, sources of free neutrons can be other than those released by fission reactors (e.g., by the alpha- $n, n-2 n$, etc.) Our suggestion is to use precise terms, such as those as defined by the International Commission on Radiation Units and Measurements (ICRU). 
Comments on Vol. II, RADTRAN IV Technical Manual

\section{Specific Comments}

1. p. 2-3, par. 4 .

In Vol. I, stated that RADTRAN IV considers 20 severity categories, which contradicts the 40 categories indicated here.

2. p. 2-8, Sec. 2.3.4.

The information on the average total photon energy per disintegration is totally useless. We is suggest that DOE dose conversion factors be used. Also, the phrase "a measure of the radiotoxicity of the dispersed material" needs to be clarified.

3. p. 2-9, Sec. 2.3.7.

Health models based on the Reactor Safety Study are outdated. Current health effects models can be found in the NRC study (NUREG/CR-4214 1988) and the BEIR V Report (National Research Council 1990).

4. p. 4-1, last par.

This paragraph states that because use of the neutrons are rapidly attenuated, gamma dose is a conservative approach. This statement is misleading for two reasons. The documentation gives the neutron dose equations (Vol. II, p. 4-10) and also stites (Vol. I) that users can input neutron contributions. This might lead users to believe that neutron doses have been incorporated into the code. Here, however, it is stated that the neutron dose calculation is replaced by the gamma dose approach because the latter is more conservative. There is no evidence to show that neutrons are more rapidly attenuated in the air than gammas (if it is the case, some references must be provided), and therefore the conservatism is not justified.

5. p. 4-2, Fig. 4-1.

Fig. 4-1 is illegible, a better figure should be provided.

6. p. 4-3, Eq. (1).

Units should be assigned for the parameters used in the equations; otherwise, it is difficult to check the derivation of the equations. 
7. p. 4-3, Eq. (2).

It is incorrect to say that the product of the attenuation and buildup factor is less than or equal to 1 . In essence, this contradicts the information provided in the same document. For example, data provided in Eq. 45 on the gamma buildup factor and attenuation coefficient are used to provide the following:

\section{Distance, $I(m)$ B(ur), exp(-ur)}

$\begin{array}{cc}0 & 1.00 \\ 05 & 1.01 \\ 10 & 1.02 \\ 30 & 1.05 \\ 50 & 1.07 \\ 100 & 1.09 \\ 150 & 1.06 \\ 200 & 1.01\end{array}$

The above table indicates by assuming the simplistic $1 / r^{2}$ relationship, that the dose can potentially be underestimated by as much as $9 \%$, within $200 \mathrm{~m}$.

8. p. 4-4, Eqs. 3, 4 and 5 .

The method used to adjust the package sizes has no basis. References are not provided to support the method nor is a justification given. In particular, a discontinuity is unexplainably given for a length of $4 \mathrm{~m}$.

9. p. 4-5, last par.

This paragraph states that the vehicle is treated as a line source at distances closer than 1 m. Because the vehicle size is greater than $1 \mathrm{~m}$, a line source would most likely underestimate the doses due to the package surface appearing more like a plane source.

10. p. 4-11, Eq. (15).

No reference is provided to support Eq. 15, no derivation or parameters are given for verification of the results. Certainly the shielding factors would be very sensitive to the gamma energies (and to the waste materials). However, there is no indication or recognition of such effect in the document. Also, if neutrons are included, the shielding factors for neutrons are different from those assumed for gammas, therefore Eq. (15) is not applicable for neutrons.

11. p. 4-28, Table 4-5.

The values of $\mathrm{Vr} / 2, \mathrm{Vs} / 2$, and $\mathrm{Vu} / 2$ are not justified for urban or suburban zones. 
12. p. $4-33$, Eqs. 44,45 and 46.

It is not clear why for the attenuation and buildup are considered for maximum individuals but not for the population dose formulation (Sec. 4.2.1). This is inconsistent.

13. p. 5-4, Sec. 5.2.2.

No references are provided throughout the discussion of the release and dispersibility. No data discussion or assumptions are provided.

14. p. $5-4$, Sec. 5.2.3.

The derivation of the material dispersal is vague. No equations parameters, are provided to arrive at the $X / Q$ values stated here.

15. p. 5-8, Table 5-1.

The wrong reference (Slade 1968) is given for the values of time-integrated air concentrations (TICs). The reference cited does not provide such information. The correct reference should be provided; otherwise, the algorithm for deriving the values should be given in the document.

16. p. 5.12, Eq. (55).

The same comment as given before regarding the validity of the assumptions about the buildup factor and the inclusion of neutron doses applies here.

17. p. 5-18, Eq. (63).

It is not clear why the isotope (i) is missing from the equation. This omission affects the ensuing derivations, all isotopes should be considered for accident doses.

18. p. 5-18, last par.

This paragraph states that Table 5-3 gives the threshold values of the health effects. A look at Table 5-3 (p. 5-20) shows that the data are for the expected latent effects. This inconsistency should be corrected.

19. p. 5-20, Table 5-3.

Again, the health effects data have been updated by the NRC Study (NUREG/CR-4214 1988) and the BEIR V Report (National Research Council 1990), and therefore the values in Table 5-3 should be replaced, since they represent the lower estimates. 
20. p.5-24, Sec. 5.6.2.

In many places the term "delayed effects" and "latent effects" are used interchangeably. We recommend the use of just one of these terms (preferably latent effects).

21. p. $5-25$, Eq. (81).

Equation 81 for the resuspension dose does not consider the activation of ground cleanup In this latter case, resuspension should be tied to the cleanup level. The equation should take this into account.

22. p. 5-27, Eq. (91).

DOE Order specifies the use of DOE published dose conversion factors (DOE/EH-0070) for ground exposures, and therefore Eq. 91 should not be used in RADTRAN to replace the DOE published factors. Use of Eq. 91 may result in erroneous results.

23. p. 5-28.

A discussion of the ground decontamination should follow the EPA guidance for accidental releases (EPA 520/1-75-001-A).

24. p. 6-6, Table 6-1.

Because the incident-free risk is directly proportional to some of the parameters listed (such as transport index (TI), package per shipment (PPS), and shipment per year (SPY), it is difficult to understand why no parameter has a sensitivity of 1 (as derived from Eq. 111). Also, the distance at stops (which is not listed in Table 6-1) can have a very high sensitivity (recall the $1 / r^{2}$ relationship used in RADTRAN). 


\section{Comments on Vol. III RADTRAN IV User Guide}

\section{Specific Comments}

1. Cover page.

This doedment should be Vol. III not II, a likely typo.

2. p. 3-27, Sec. 3.6.3.

When default values are given, references for these values should also be provided. If not, a rationale must be given for the validity of such data.

3. p. $4-4$, Sec. 4.4 .

The equation provided in this section for package size adjustment is not supported by any studies; either references or justifications should be given here.

4. p. $4-10$, Sec. 4.8 .

Derivation of the attenuation curve for neutrons is not supported by any valid documentation or references. Also, no references are provided for the NJOY or ONEDANT code cited in this section. The assumption of $50 \%$ humidity is not justified (it is not clear whether it represents the U.S. average or any local humidity data). Also, the equation has not been incorporated into the dose consideration as the documentation claims.

5. p. 4-12, Table 4-3.

Again, references should be provided for the data given in Table 4-3.

6. p. $4-15$, par. 1 .

The multipliers $(0.52,8.60 \mathrm{E}-03$, and 0.1 are provided without justification or references. An explanation or references should be supplied.

7. p. $5-1$, Sec. 5.0

We suggest that output options: since a number of users may only be interested in the summary results (usually for those doing the production reruns), such an option should be provided. 


\section{Comments on Vol. IV, RADTRAN IV Programmer Guide}

\section{General Comments}

1. The documentation that we received is incomplete. A major component of the programmer's guide, the source code is not included, despite a reference to it (p. 1-3/4). Without this list it is impossible to determine how well the code was documented or structured (i.e., the use of common blocks, the separation of functions, and the use of FORTRAN-structured commands). To determine whether the code can be easily followed and changed and, in general, well maintained and verifiable, this list must be provided.

2. Another piece of missing information is the relationship between the subroutines and the data files that are needed and generated. The introductory chapter states that this information is in Chapter 2 (p. 1-3/4). However, the only mention of data files occurs when it is stated that for reasons of integrity, the names cannot be released (p. 2-3/4). The necessary data files should be listed and referenced, so that the source of the default data is clear.

3. The physical bulk of this guide is the computer-generated mapping of the variables and subroutines (Appendix A). This list seems to be redundant with the information in Chapter 4. This guide would be better if Appendix A were removed.

4. The documentation of the variables and subroutines should be supplemented with a diagram showing the relationships among the subroutines. This should be a bit more detailed than Fig. 1.2; the reader should not be required to get this information directly from the code. Also, information about the relationships among the subroutines and variables should be included in Table 3-1 (e.g., a listing of the passed parameters and common blocks used for each subroutine).

5. One of the major improvements of RADTRAN IV as stated is the interface between the user and the heart of the code. This interface code is however not mentioned here. It is important to know the structure, assumptions, limitations, and defaults of this code. This information should appear in this volume.

6. Chapter 5 should start with the paragraph in Sec. 5.2 because only the output data file is presented in Appendixes B and C. The current first sentence of Sec. 5.1 should be removed. Some text error occurs in Chapter 5: in the first sentence of Sec. 5.2, inputted should be input; in the third sentence of Sec. 5.3, "benchmark texts" should be changed to "benchmark tests"; in the third sentence of the second paragraph of Sec. 5.3, the version of RADTRAN tested against TREC II does not agree with the date of the reference given.

7. The comparison with the NUREG-0170 data set should be more detailed. Exactly what aspects of the code were tested? How exhaustive were these tests? Did they test the menu-driven input feature of RADTRAN IV? Were any hand calculations performed and documented? 


\section{APPENDIX B}

This RISKIND sample problem considers accident conditions during transport in California. In this problem, only an urban population zone is considered - no individual receptor locations are analyzed. It was interesting to note that no input data page (as shown in the RISKIND manual) was produced during the output. To produce this, the user must execute a print out of the RISKIND.INP file separately from the RISKIND output module. The input data for this sample problem are located on pages 1B and 2B.

The first 4 pages of the sample problem output describe the input parameters and the urban population zone's calculated dose. No specific route was selected - this problem simulated a truck passing through an urban center on an 8.0 meter wide road. The spent fuel is assumed to be pressurized-water reactor (PWR) fuel and a 10-year cooling period. The population density was set at $3861 / \mathrm{km} 2$. The accident probability is 1.0 since the consequences, not the risk, are calculated. The shipping cask is assumed to be a GA-4 truck cask with a transportation index of 10 . The radiation field is $100 \%$ gamma and $0 \%$ neutron in dose.

The remaining portion of the output includes a list of the radionuclides that have been screened and selected according to their importance, and the consequences for each of the 20 cask response regions for the input accident conditions. Finally, a summary of the calculated consequences for the 50-year committed effective dose equivalent and the probability of early fatalities is also presented. 
\&INDATA

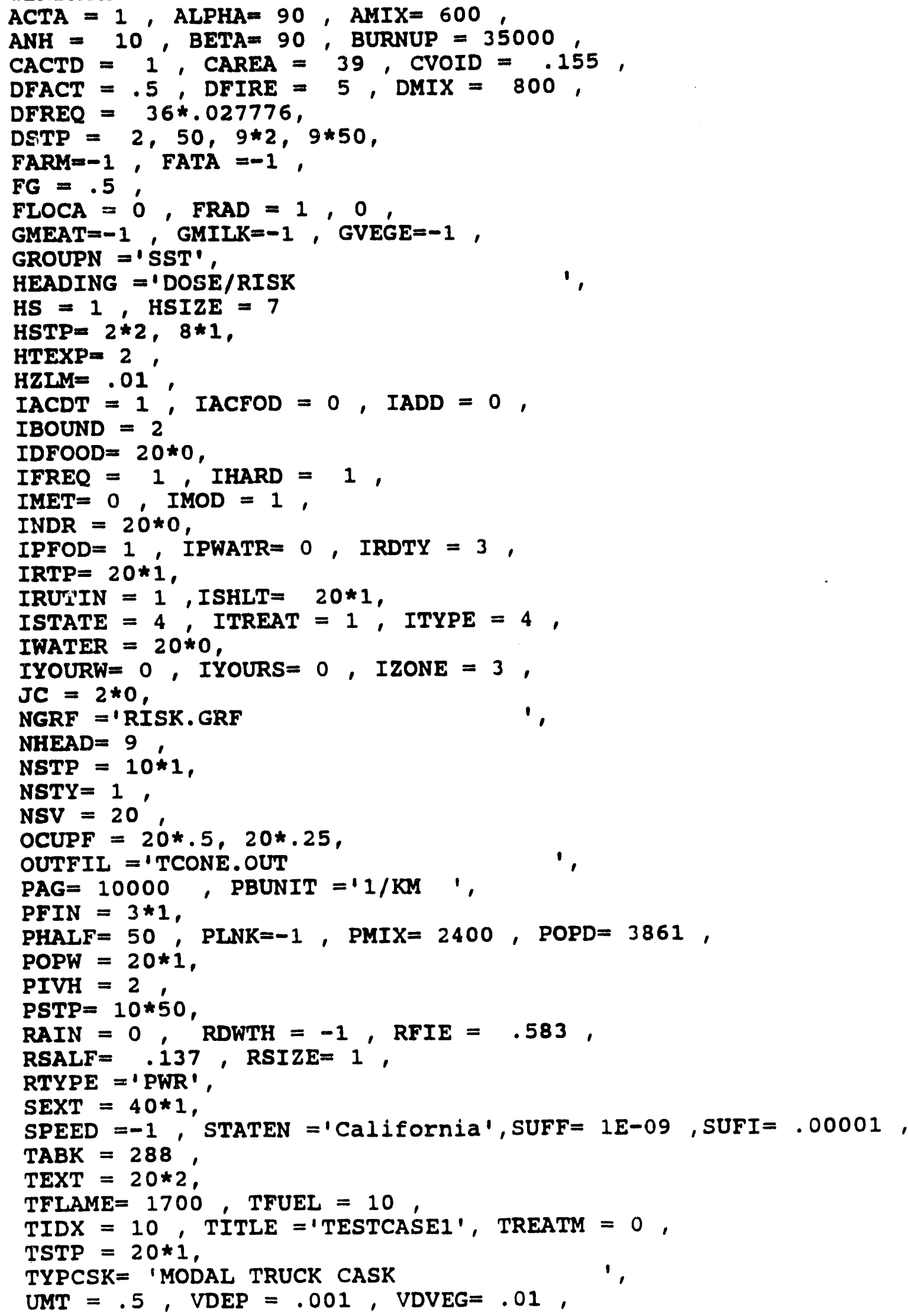




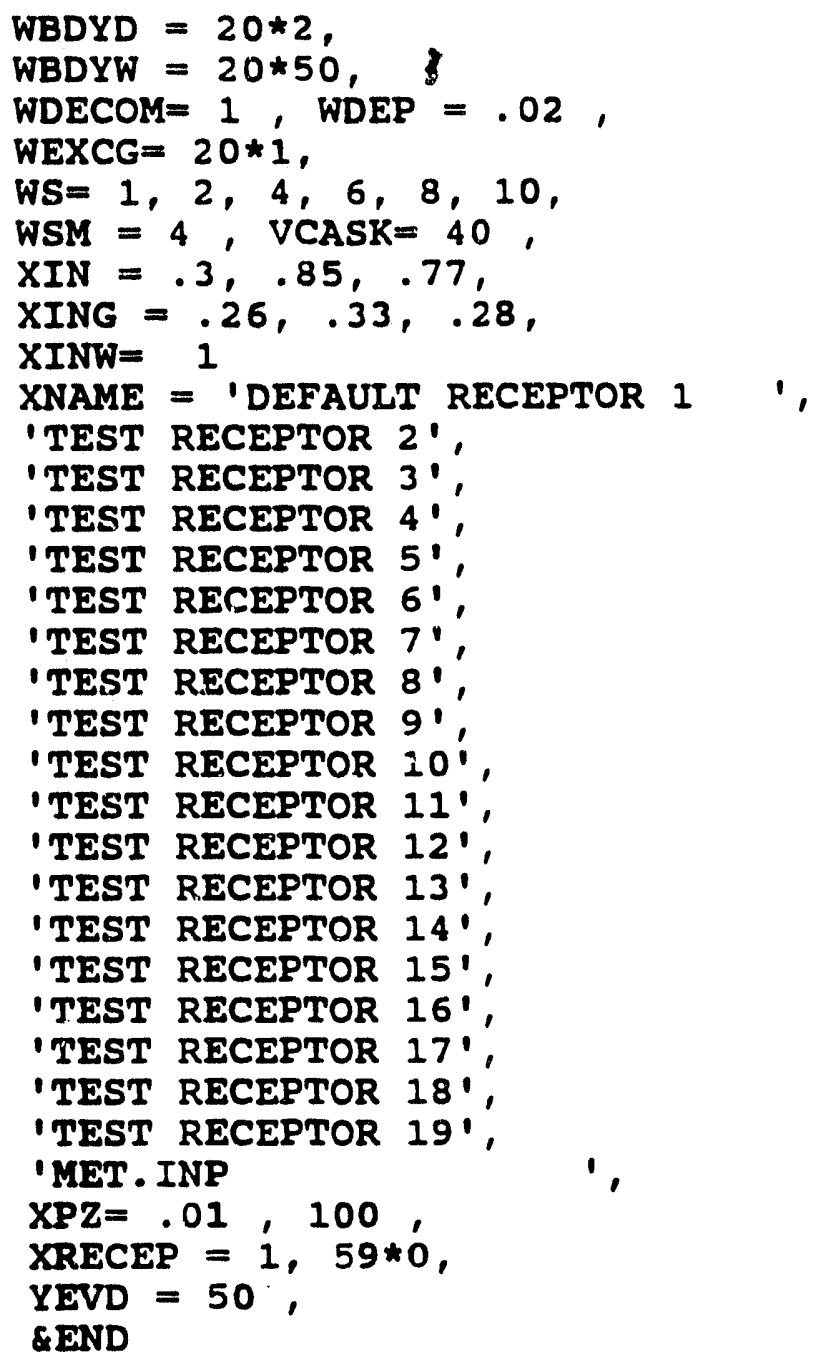


BACKGROUND POPULATION INFORMATION :

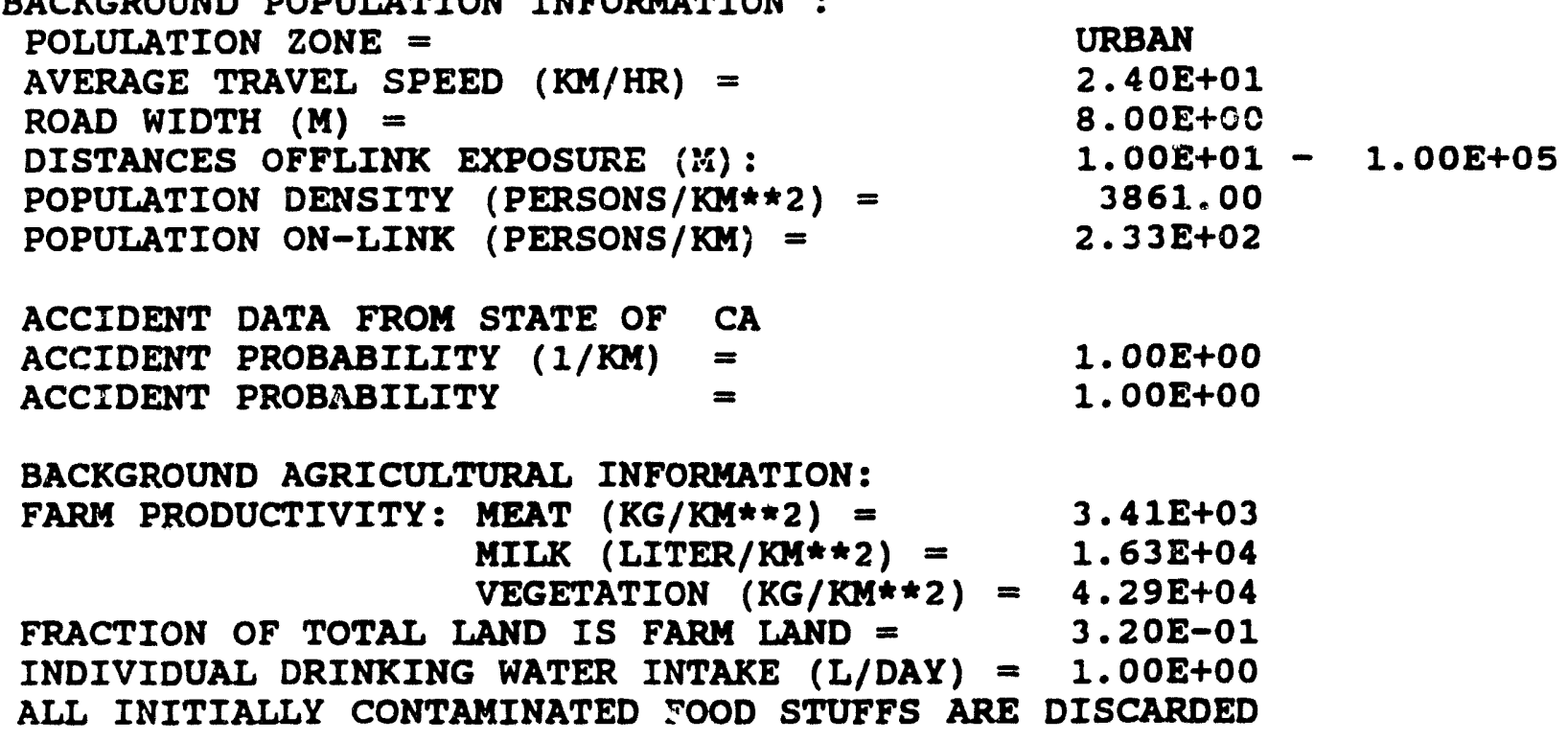

ANNUAL FREQUENCE OF OCCURENCE -- SUM OF ALL WIND DIRECTIONS
SPEED, M/S

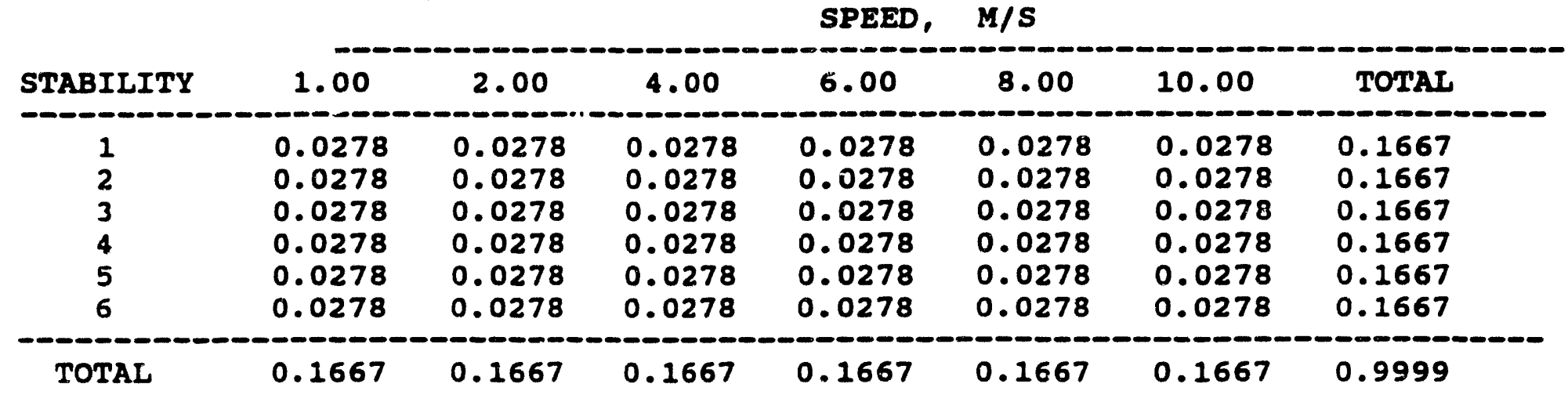

TRANSPORTATION MODE =

Cask Type

Reactor Type

Fuel Burnup

spent Fuel storage Time=

MTU per Shipment $=$
TRUCK

MODAL TRUCK

PWR

35000.0 MWD

10.0 years

0.50

Radionuclide Inventory Per Metric Ton of Uranium

Tutal Isotopes

Total Curies

$\begin{array}{ll}= & 205 \\ = & 4.18 \mathrm{E}+05\end{array}$

CRUD INFORMATION

CASK Void Volume

CASK Cavity Surface Area

$=$

$=$

Co-60 Activity Density at Discharge =

co-60 Activity in Cask at Discharge=

co-60 Activity in Cask During transport=
$18 \mathrm{E}+05$

$0.2 \mathrm{~m} 3$

$39.0 \mathrm{~m} 2$

1. $0 \mathrm{micro} \mathrm{Ci} / \mathrm{cm} 2$

$0.4 \mathrm{CI}$

$0.1 \mathrm{Cl}$ 
FRACTION RELEASED AND ALSO DISPERSED FOR EACH RESPONSE REGION

\begin{tabular}{|c|c|c|c|c|c|c|c|c|c|c|}
\hline \multirow{2}{*}{$\begin{array}{l}\text { NUCLIDE } \\
\text { TYPE }\end{array}$} & \multicolumn{10}{|c|}{ RESPONSE REGEON } \\
\hline & 1 & 2 & 3 & 4 & 5 & 6 & 7 & 8 & 9 & 10 \\
\hline $\begin{array}{l}\text { PART. } \\
\text { RU } \\
\text { CS } \\
\text { IODINE } \\
\text { GAS } \\
\text { CRUD }\end{array}$ & $\begin{array}{l}0 . E+00 \\
0 . E+00 \\
0 . E+00 \\
0 . E+00 \\
0 . E+00 \\
0 . E+00\end{array}$ & $\begin{array}{l}2 \cdot E-07 \\
3 \cdot E-06 \\
2 \cdot E-05 \\
3 \cdot E-04 \\
3 \cdot E-02 \\
1 . E+00\end{array}$ & $\begin{array}{l}2 \cdot E-06 \\
3 \cdot E-05 \\
2 \cdot E-04 \\
2 \cdot E-03 \\
3 \cdot E-01 \\
1 \cdot E+00\end{array}$ & $\begin{array}{l}2 \cdot E-05 \\
3 \cdot E-04 \\
2 \cdot E-03 \\
4 \cdot E-02 \\
6 \cdot E-01 \\
1 \cdot E+00\end{array}$ & $\begin{array}{l}\text { 6. E-08 } \\
8 \cdot E-07 \\
6 \cdot E-06 \\
7 \cdot E-05 \\
1 . E-02 \\
2 \cdot E-01\end{array}$ & $\begin{array}{l}2 \cdot E-07 \\
3 \cdot E-06 \\
2 \cdot E-05 \\
3 \cdot E-04 \\
3 \cdot E-02 \\
1 \cdot E+00\end{array}$ & $\begin{array}{l}2 \cdot E-06 \\
3 \cdot E-05 \\
2 \cdot E-04 \\
2 \cdot E-03 \\
3 \cdot E-01 \\
1 \cdot E+00\end{array}$ & $\begin{array}{l}2 \cdot E-05 \\
3 \cdot E-04 \\
2 \cdot E-03 \\
4 \cdot E-02 \\
6 \cdot E-01 \\
1 \cdot E+00\end{array}$ & $\begin{array}{l}6 \cdot E-08 \\
8 \cdot E-07 \\
6 . E-06 \\
7 \cdot E-05 \\
1 . E-02 \\
2 . E-01\end{array}$ & $\begin{array}{l}2 \cdot E-07 \\
3 \cdot E-06 \\
2 \cdot E-05 \\
3 \cdot E-04 \\
3 \cdot E-02 \\
1 \cdot E+00\end{array}$ \\
\hline
\end{tabular}

PROB 1.E+00 4.E-03 2.E-03 2.E-07 2.E-05 2.E-07 2.E-07 $4 \cdot E-14 \quad 2 . E-05 \quad 3 . E-07$

FRACTION RELEASED AND ALSO DISPERSED FOR EACH RESPONSE REGION

\section{NUCLIDE}

TYPE

\begin{tabular}{|c|c|c|c|c|c|c|c|c|c|c|}
\hline & 11 & 12 & 13 & 14 & 15 & 16 & 17 & 18 & 19 & 20 \\
\hline $\begin{array}{l}\text { PART. } \\
\text { RU } \\
\text { CS } \\
\text { IODINE } \\
\text { GAS } \\
\text { CRUD }\end{array}$ & $\begin{array}{l}2 \cdot E-06 \\
3 \cdot E-05 \\
2 \cdot E-04 \\
2 \cdot E-03 \\
3 \cdot E-01 \\
1 \cdot E+00\end{array}$ & $\begin{array}{l}2 \cdot E-05 \\
3 \cdot E-04 \\
2 \cdot E-03 \\
4 \cdot E-02 \\
6 \cdot E-01 \\
1 \cdot E+00\end{array}$ & $\begin{array}{l}2 \cdot E-06 \\
5 \cdot E-05 \\
2 \cdot E-04 \\
4 \cdot E-03 \\
4 \cdot E-01 \\
2 \cdot E-01\end{array}$ & $\begin{array}{l}2 \cdot E-06 \\
5 \cdot E-05 \\
2 \cdot E-04 \\
4 \cdot E-03 \\
4 \cdot E-01 \\
1 \cdot E+00\end{array}$ & $\begin{array}{l}2 \cdot E-06 \\
5 \cdot E-05 \\
2 \cdot E-04 \\
4 \cdot E-03 \\
4 \cdot E-01 \\
1 \cdot E+00\end{array}$ & $\begin{array}{l}2 \cdot E-05 \\
5 \cdot E-04 \\
2 \cdot E-03 \\
4 \cdot E-02 \\
6 \cdot E-01 \\
1 \cdot E+00\end{array}$ & $\begin{array}{l}2 \cdot E-05 \\
5 \cdot E-04 \\
2 \cdot E-03 \\
4 \cdot E-02 \\
6 \cdot E-01 \\
2 \cdot E-01\end{array}$ & $\begin{array}{l}2 \cdot E-05 \\
5 \cdot E-04 \\
2 \cdot E-03 \\
4 \cdot E-02 \\
6 \cdot E-01 \\
1 \cdot E+00\end{array}$ & $\begin{array}{l}2 \cdot E-05 \\
5 \cdot E-04 \\
2 \cdot E-03 \\
4 \cdot E-02 \\
6 \cdot E-01 \\
1 \cdot E+00\end{array}$ & $\begin{array}{l}2 \cdot E-05 \\
5 \cdot E-04 \\
2 \cdot E-03 \\
4 \cdot E-02 \\
6 \cdot E-01 \\
1 \cdot E+00\end{array}$ \\
\hline
\end{tabular}

\section{RESPONSE REGION}

PROB 2.E-07 1.E-14 2.E-05 2.E-07 1.E-07 8.E-16 1.E-05 7.E-08 $5 . E-08 \quad 1 . E-16$ 
EXTERNAL DOSE RATE MULTIPLIER FOR EACH ACCIDENT RESPONSE REGION

\section{TYPE} (MULTIPLIER OF TI)

\begin{tabular}{lllllllllll} 
& 1 & 2 & 3 & 4 & 5 & 6 & 7 & 8 & 9 & 10 \\
\hline GAMMA & 1.00 & 1.00 & 1.00 & 1.00 & 1.00 & 1.00 & 1.00 & 1.00 & 1.00 & 1.00 \\
NUTRN & 1.00 & 1.00 & 1.00 & 1.00 & 1.00 & 1.00 & 1.00 & 1.00 & 1.00 & 1.00
\end{tabular}

EXTERNAL DOSE RATE MULTIPLIER FOR EACH ACCIDENT RESPONSE REGION TYPE (MULTIPLIER OF TI)

\begin{tabular}{|c|c|c|c|c|c|c|c|c|c|c|}
\hline TYPE & 11 & 12 & 13 & 14 & $\begin{array}{l}\text { ESPONSE } \\
15\end{array}$ & $\begin{array}{l}\text { REGION } \\
16\end{array}$ & 17 & 18 & 19 & 20 \\
\hline $\begin{array}{l}\text { GAMMA } \\
\text { NUTRN }\end{array}$ & $\begin{array}{l}1.00 \\
1.00\end{array}$ & $\begin{array}{l}1.00 \\
1.00\end{array}$ & $\begin{array}{l}1.00 \\
1.00\end{array}$ & $\begin{array}{l}1.00 \\
1.00\end{array}$ & $\begin{array}{l}1.00 \\
1.00\end{array}$ & $\begin{array}{l}1.00 \\
1.00\end{array}$ & $\begin{array}{l}1.00 \\
1.00\end{array}$ & $\begin{array}{l}1.00 \\
1.00\end{array}$ & $\begin{array}{l}1.00 \\
1.00\end{array}$ & $\begin{array}{l}1.0 \\
1.0\end{array}$ \\
\hline
\end{tabular}


CASK SIZE : RADIUS $(M)=$ LENGTH $(M)=$ FRACTION GAMIA SOURCE = FRACTION NEUTRON SOURCE $=\ldots$ TRANSPORTATION INDEX =
1. $00 \mathrm{E}+00$

$7.00 \mathrm{E}+00$

1.00

0.00

10.00

INCIDENT FREE UNIT RISK FACTORS :

OFFLINK UNIT RISK FACTOR, (P-REM/KM) $=1.45 \mathrm{E}-03$

ONLINK UNIT RISK FACTOR, (P-REM/KK) $=5.46 \mathrm{E}-03$

OFFLINK STOP RISK FACTOR, (P-REM/HR) $=2.05 \mathrm{E}-03$

SPECIAL STOP LOCATION DOSE FACTORS:

$\begin{array}{ccccc}\text { STOP } & \text { STOP TIME } & \text { DISTANCES } & \text { OF PEOPLE } & \text { DOSE(PESON-REM) } \\ 1 & 2.00 E+00 & 2.00 E+00-5.00 E+01 & 5.00 E+01 & 9.68 E-03\end{array}$

TOTAL POPULATION DOSE FROM STOPS (PERSON-REM) $=9.68 \mathrm{E}-03$ 
ACCIDENT RESPONSE REGION STRUCTURE. RESPONSE WITHIN TEMPERATURE LEVEL WITHIN

ACCIDENT SCENARIO PROBABILITY
$(1 / \mathrm{KM}$
1

0.20 PERCENT STRAINS 500. DEGREE $F$

9:S4E-01

\&\&\&\&\&\&\&\& NO ACCIDENT RELEASES \&\&\&\&\&\&\& 
SUMMARY OF POTENTIAL POPULATION DOSE CONSEQUENCES FATALITY AND GENETIC RISKS

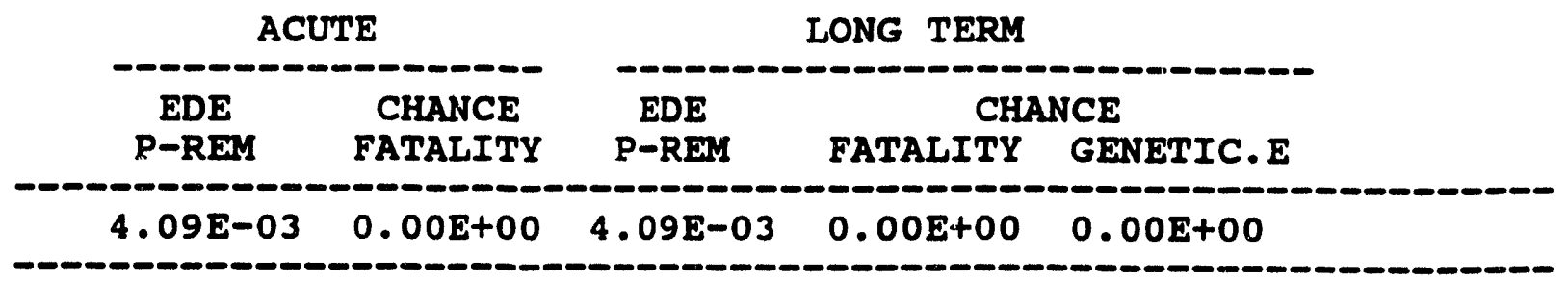


ACCIDENT RESPONSE REGION STRUCTURE RESPONSE WITHIN TEMPERATURE LEVEL WITHIN ACCIDENT SCENARIO PROBAEIIIT
2

2.00 PERCENT STEAINS 500. DEGREE $F$ $3.82 \mathrm{E}-03$

\begin{tabular}{|c|c|c|c|c|c|c|}
\hline \multirow{2}{*}{\multicolumn{2}{|c|}{ NUCLIDE }} & \multirow[t]{2}{*}{$\operatorname{DCAY}(1 / Y R)$} & \multirow[t]{2}{*}{ CURIE } & \multicolumn{3}{|c|}{ REIATIVE HAZARD } \\
\hline & & & & ACUTE & INGESTION & G.SHINE \\
\hline $\begin{array}{l}\text { CO } \\
\text { KR } \\
\text { SR } \\
\text { CS } \\
\text { CS } \\
\text { PU } \\
\text { PU } \\
\text { PU } \\
\text { PU } \\
\text { AM } \\
\text { CM }\end{array}$ & $\begin{array}{r}60 \\
85 \\
90 \\
134 \\
137 \\
238 \\
239 \\
240 \\
241 \\
241 \\
244\end{array}$ & $\begin{array}{l}1.30 \mathrm{E}-01 \\
6.50 \mathrm{E}-02 \\
2.40 \mathrm{E}-02 \\
3.40 \mathrm{E}-01 \\
2.30 \mathrm{E}-02 \\
7.90 \mathrm{E}-03 \\
2.90 \mathrm{E}-05 \\
1.10 \mathrm{E}-04 \\
4.80 \mathrm{E}-02 \\
1.60 \mathrm{E}-03 \\
3.80 \mathrm{E}-02\end{array}$ & $\begin{array}{l}8.75 \mathrm{E}+02 \\
2.64 \mathrm{E}+03 \\
3.17 \mathrm{E}+04 \\
2.59 \mathrm{E}+03 \\
4.31 \mathrm{E}+04 \\
1.15 \mathrm{E}+03 \\
1.73 \mathrm{E}+02 \\
2.39 \mathrm{E}+02 \\
4.21 \mathrm{E}+04 \\
9.45 \mathrm{E}+02 \\
4.51 \mathrm{E}+02\end{array}$ & $\begin{array}{l}6.26 \mathrm{E}-02 \\
2.27 \mathrm{E}-02 \\
2.22 \mathrm{E}-02 \\
6.51 \mathrm{E}-03 \\
7.44 \mathrm{E}-02 \\
2.42 \mathrm{E}-01 \\
3.95 \mathrm{E}-02 \\
5.48 \mathrm{E}-02 \\
1.86 \mathrm{E}-01 \\
2.24 \mathrm{E}-01 \\
5.98 \mathrm{E}-02\end{array}$ & $\begin{array}{l}1.12 \mathrm{E}-02 \\
0.00 \mathrm{E}+00 \\
1.39 \mathrm{E}-02 \\
1.05 \mathrm{E}-02 \\
9.62 \mathrm{E}-01 \\
1.84 \mathrm{E}-04 \\
3.61 \mathrm{E}-05 \\
4.99 \mathrm{E}-05 \\
7.28 \mathrm{E}-05 \\
1.98 \mathrm{E}-04 \\
2.69 \mathrm{E}-04\end{array}$ & $\begin{array}{l}1.26 \mathrm{E}-01 \\
0.00 \mathrm{E}+00 \\
0.00 \mathrm{E}+00 \\
1.74 \mathrm{E}-02 \\
8.56 \mathrm{E}-01 \\
4.55 \mathrm{E}-07 \\
3.54 \mathrm{E}-08 \\
1.06 \mathrm{E}-07 \\
0.00 \mathrm{E}+00 \\
1.46 \mathrm{E}-05 \\
1.01 \mathrm{E}-07\end{array}$ \\
\hline & TAL & & & $9.94 E-01$ & $9.99 \mathrm{E}-01$ & $1.00 \mathrm{E}+00$ \\
\hline
\end{tabular}




\begin{tabular}{lccc} 
NUCLIDE & INVENTORY (C1) & FRAC-REL & C1-REL \\
\hline CO 60 & $8.75 \mathrm{E}+02$ & $1.22 \mathrm{E}-04$ & $1.07 \mathrm{E}-01$ \\
KR 85 & $2.64 \mathrm{E}+03$ & $3.30 \mathrm{E}-02$ & $8.73 \mathrm{0}+01$ \\
SR 90 & $3.17 \mathrm{E}+04$ & $2-00 \mathrm{E}-07$ & $6.36 \mathrm{E}-03$ \\
CS 134 & $2.59 \mathrm{E}+03$ & $2.00 \mathrm{E}-05$ & $5.20 \mathrm{E}-02$ \\
$\mathrm{CS} 137$ & $4.31 \mathrm{E}+04$ & $2.00 \mathrm{E}-05$ & $8.65 \mathrm{E}-01$ \\
PU 238 & $1.15 \mathrm{E}+03$ & $2.00 \mathrm{E}-07$ & $2.32 \mathrm{E}-04$ \\
PU 239 & $1.73 \mathrm{E}+02$ & $2.00 \mathrm{E}-07$ & $3.46 \mathrm{E}-05$ \\
PU 240 & $2.39 \mathrm{E}+02$ & $2.00 \mathrm{E}-07$ & $4.79 \mathrm{E}-05$ \\
PU 241 & $4.21 \mathrm{E}+04$ & $2.00 \mathrm{E}-07$ & $8.44 \mathrm{E}-03$ \\
AU 241 & $9.45 \mathrm{E}+02$ & $2.00 \mathrm{E}-07$ & $1.89 \mathrm{E}-04$ \\
CI 244 & $4.51 \mathrm{E}+02$ & $2.00 \mathrm{E}-07$ & $9.04 \mathrm{E}-05$ \\
\hline
\end{tabular}




\section{DISPERSION CALCULATION PARAMETERS:}

$\begin{array}{lr}\text { PHYSICAL RELEASE HEIGHT (M) }= & 1.00 \\ \text { DEPOSITION VELOCITY (M/S) }= & 0.0010 \\ \text { POPULATION ZONE } \equiv & \text { URBAN } \\ \text { ANAMETER HEIGHT (M) }= & 10.00 \\ \text { AMBIENT TEMPERATURE (K) }= & 288.00 \\ \text { SOURCE HORIZONTAL SIZE }(M)= & 3.74\end{array}$

SUMMARY OF POTENTIAL DOSE CONSEQUENCES

I LOCATION

WEATHER PERCENTILE
ACUTE EDE P-REM
TOTAL EDE

$50 \%$ P-REM $95 \%$

$$
\text { P-REM }
$$

1 WHOLE POPULATION

$$
3.28 \mathrm{E}+01 \quad 2.36 \mathrm{E}+02
$$

$1.72 \mathrm{E}+02$

$1.35 \mathrm{E}+03$

SUMMARY OF POTENTIAL HEALTH CONSEQUENCES

I LOCATION

(WEATHER PERCENTILE)

\section{ACUTE}

FATALITY
LATENT

FATALITY $50 \% \quad 95 \%$ $95 \%$

GENETIC EFFECT 
ACCIDENT RESPONSE REGION STRUCTURE RESPONSE WITHIN TEMPERATURE LEVEL WITHIN ACCIDENT SCENARIO PROBABILITY
3

30.00 PERCENT STRAINS

500. DEGREE $F$

$1.80 \mathrm{E}-03$

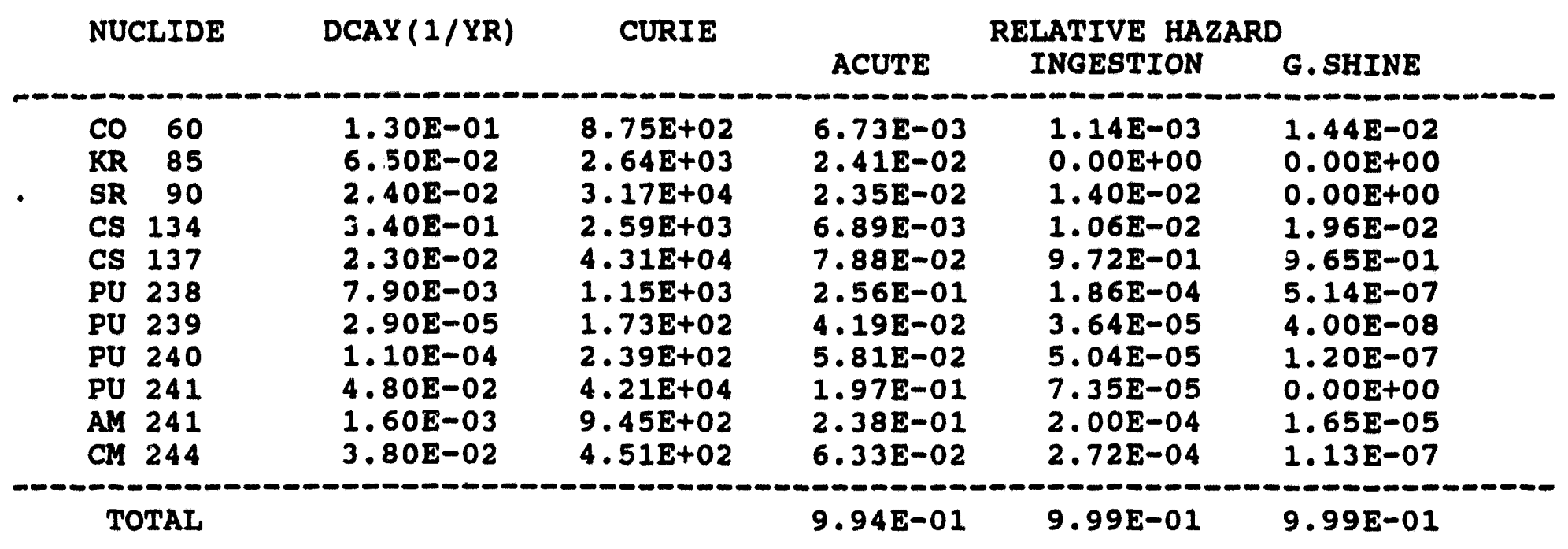




\begin{tabular}{|c|c|c|c|}
\hline NUCLIDE & INVENTORY (C1) & FRAC-REL & CI-REL \\
\hline $\begin{array}{lr}\text { CO } & 60 \\
\text { KR } & 85 \\
\text { SR } & 90 \\
\text { CS } & 134 \\
\text { CS } & 137 \\
\text { PU } & 238 \\
\text { PU } & 239 \\
\text { PU } & 240 \\
\text { PU } & 241 \\
\text { AM } & 241 \\
\text { CM } & 244\end{array}$ & $\begin{array}{l}8.75 \mathrm{E}+02 \\
2.64 \mathrm{E}+03 \\
3.17 \mathrm{E}+04 \\
2.59 \mathrm{E}+03 \\
4.31 \mathrm{E}+04 \\
1.15 \mathrm{E}+03 \\
1.73 \mathrm{E}+02 \\
2.39 \mathrm{E}+02 \\
4.21 \mathrm{E}+04 \\
9.45 \mathrm{E}+02 \\
4.51 \mathrm{E}+02\end{array}$ & $\begin{array}{l}1.23 \mathrm{E}-04 \\
3.30 \mathrm{E}-01 \\
2.00 \mathrm{E}-06 \\
2.00 \mathrm{E}-04 \\
2.00 \mathrm{E}-04 \\
2.00 \mathrm{E}-06 \\
2.00 \mathrm{E}-06 \\
2.00 \mathrm{E}-06 \\
2.00 \mathrm{E}-06 \\
2.00 \mathrm{E}-06 \\
2.00 \mathrm{E}-06\end{array}$ & $\begin{array}{l}1.08 \mathrm{E}-01 \\
8.73 \mathrm{E}+02 \\
6.36 \mathrm{E}-02 \\
5.20 \mathrm{E}-01 \\
8.65 \mathrm{E}+00 \\
2.32 \mathrm{E}-03 \\
3.46 \mathrm{E}-04 \\
4.79 \mathrm{E}-04 \\
8.44 \mathrm{E}-02 \\
1.89 \mathrm{E}-03 \\
9.04 \mathrm{E}-04\end{array}$ \\
\hline
\end{tabular}

SUMMARY OF POTENTIAL DOSE CONSEQUENCES

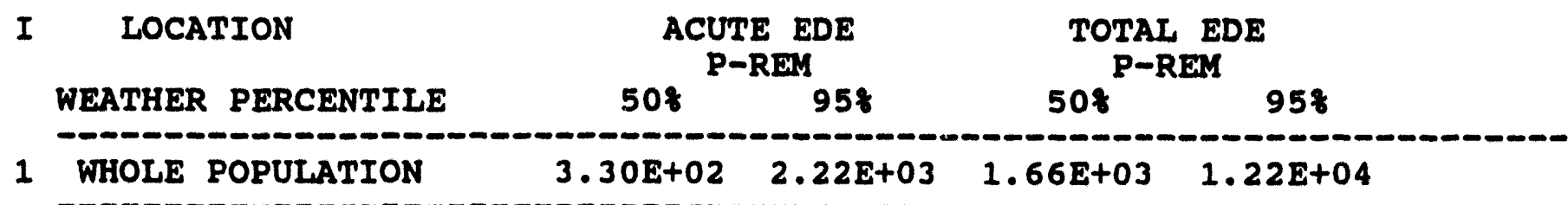

SUMMARY OF POTENTIAL HEALTH CONSEQUENCES

$\begin{array}{cccc}\text { I LOCATION } & \text { ACUTE } & \text { LATENT } & \text { GENETIC } \\ \text { (WEATHER PERCENTILE) } & \text { FATALITY } & \text { FATALITY } & \text { EFFECT }\end{array}$


ACCIDENT RESPONSE REGION STRUCTURE RESPONSE EXCEED TEMPERATURE LEVEL WITHIN ACCIDENT SCENARIO PROBABILIT

\subsection{PERCENT STRAINS 500. DEGREE $F$} $1.53 \mathrm{E}-07$

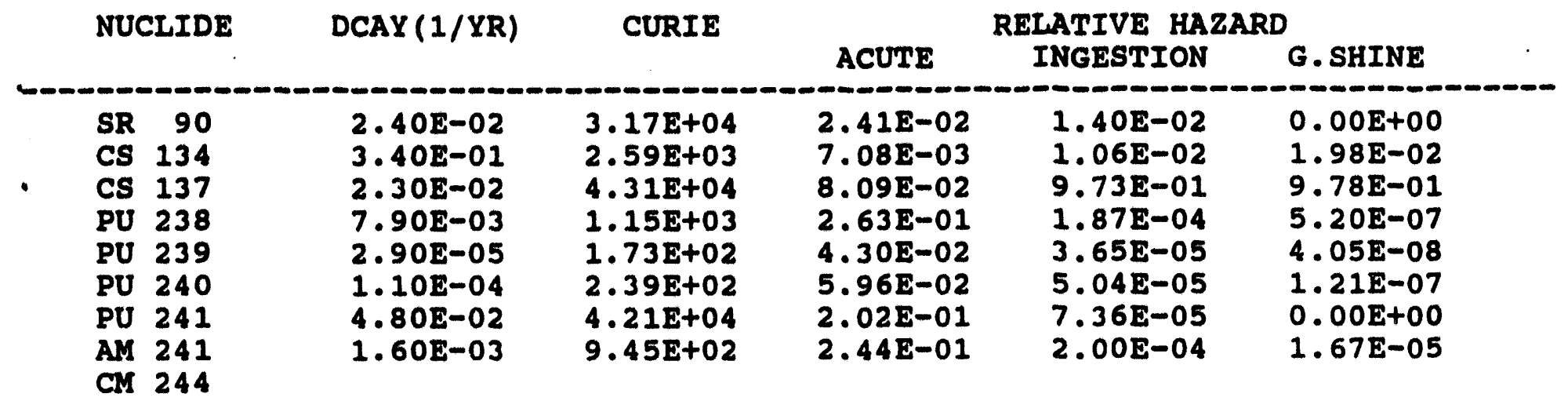

\section{TESTCASE? \\ RISKIND: OCRIM (2/93)
ACCIDENT RESPONSE REGION STRUCTURE RESPOUSE EXCEED TEMPERATURE LEVEL WITHIN ACCIDENT SCEMARIO PROBABILITY (1/KM )
4
30.00 PERCENT STRAINS 300. DEGREE $F$ \\ $1.53 E-07$}

09/17/93 17:23 PACE 12

\begin{tabular}{|c|c|c|c|c|c|}
\hline \multirow[t]{2}{*}{ MUCLIOE } & \multirow[t]{2}{*}{$\operatorname{DCAY}(1 / Y R)$} & \multirow[t]{2}{*}{ Cunie } & \multicolumn{3}{|c|}{ RELATIVE HAZARD } \\
\hline & & & ACUTE & IMEESTION & G.SHINE \\
\hline SR 90 & $2.40 E-02$ & $3.17 E+06$ & $2.61 E-02$ & $1.602-02$ & $0.00 E+00$ \\
\hline $\operatorname{cs} 134$ & $3.40 E-01$ & $2.59 \varepsilon+03$ & $7.08 E-03$ & $1.068-02$ & $1.988-02$ \\
\hline $\operatorname{Cs} 137$ & $2.30 \varepsilon-02$ & $4.31 E+04$ & $8.09 E-02$ & $9.73 E-01$ & $9.78 E \cdot 01$ \\
\hline PU 238 & $7.905-03$ & $1.15 E+03$ & $2.63 E-01$ & $1.87 E-04$ & 5.20E-07 \\
\hline PU 239 & $2.90 E-05$ & $1.73 E+02$ & $4.30 E-02$ & $3.65 E-05$ & $4.05 E-08$ \\
\hline PU 240 & $1.10 E-04$ & $2.39 \%+02$ & $5.96 E-02$ & $5.04 E-05$ & $1.21 E \cdot 07$ \\
\hline PU 261 & $4.80 E-02$ & $4.21 E+04$ & $2.02 E-01$ & $7.36 E-05$ & $0.00 E+00$ \\
\hline NM 261 & $1.60 \mathrm{E}-03$ & $9.45 E+02$ & $2.46 E-01$ & $2.00 E-04$ & $1.67 \varepsilon-05$ \\
\hline CN 244 & $3.80 E-02$ & $4.51 E+02$ & $6.50 E-02$ & $2.72 E-04$ & $1.15 E-07$ \\
\hline
\end{tabular}




\begin{tabular}{|c|c|c|c|}
\hline \multicolumn{3}{|l|}{ TESTCASE 1} & \multirow[t]{2}{*}{$09 / 17 / 93$} \\
\hline RISKIND: OCRW & $(2 / 93)$ & e: RISKIND & \\
\hline NUCLIOE & INVENTORY(CI) & FRAC-REL & CI-REL \\
\hline \multicolumn{4}{|l|}{$\ldots \ldots$} \\
\hline SR 90 & $3.17 E+04$ & $2.00 E-05$ & 6.37E-01 \\
\hline CS 134 & $2.59 E+03$ & $2.00 E \cdot 03$ & $5.22 E+00$ \\
\hline CS 137 & $4.31 E+04$ & $2.00 E-03$ & $8.67 E+01$ \\
\hline PU 238 & $1.15 E+03$ & $2.00 E-05$ & $2.32 E-02$ \\
\hline PU 239 & $1.73 E+02$ & $2.00 E-05$ & $3.47 E-03$ \\
\hline PU 240 & $2.39 E+02$ & $2.00 E-05$ & $4.80 E-03$ \\
\hline PU 241 & $4.21 E+04$ & $2.00 E-05$ & $8.46 E-01$ \\
\hline AM 241 & $9.45 E+02$ & $2.00 E-05$ & $1.90 E-02$ \\
\hline CM 244 & $4.51 E+02$ & $2.00 E-05$ & 9.0TE-03 \\
\hline
\end{tabular}

SUMMARY OF POTENTIAL DOSE CONSEQUENCES

\begin{tabular}{|c|c|c|c|c|}
\hline \multirow{2}{*}{$\begin{array}{l}\text { I LOCATION } \\
\text { MEATHER PERCENTILE }\end{array}$} & \multicolumn{2}{|c|}{$\begin{array}{c}\text { ACUTE EDE } \\
\text { P-REM }\end{array}$} & \multicolumn{2}{|c|}{$\begin{array}{c}\text { TOTAL EDE } \\
\text { P-REM }\end{array}$} \\
\hline & $50 \%$ & $95 x$ & $50 x$ & $95 \%$ \\
\hline 1 WHOLE POPULATION & $3.28 E+03$ & $2.21 E+04$ & $1.65 E+04$ & $1.20 E+05$ \\
\hline
\end{tabular}

SUMMARY OF POTENTIAL HEALTH CONSEQUENCES

\begin{tabular}{|c|c|c|c|}
\hline LOCATION & $\begin{array}{l}\text { ACUTE } \\
\text { FATALITY }\end{array}$ & $\begin{array}{l}\text { LATENT } \\
\text { FATALITY }\end{array}$ & $\begin{array}{l}\text { GENETIC } \\
\text { EFFECT }\end{array}$ \\
\hline (WEATHER PERCENTILE) & $50 x \quad 95 \%$ & $50 x \quad 95 x$ & $50 x \quad 95 x$ \\
\hline
\end{tabular}

1 HMOLE POPULATION $0.00 E+00 \quad 1.00 E+001.32 E+01 \quad 9.63 E+01 \quad 3.29 E+00 \quad 2.41 E+01$




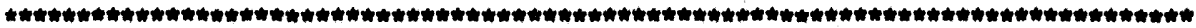

TESTCASE 1

RISKIND: OCRIN (2/93)

File: RISKIND.INP

ACCIDENT RESPONSE REGION STRUCTURE RESPONSE MITHIM TEMPERATURE LEVEL WITHIN

ACCIDENT SCENARIO PROBABILITY (1/KM ) $=1.69 E-05$

NUCLIDE DCAY(1/YR) CURIE

\begin{tabular}{lllllll} 
CO 60 & $1.30 E-01$ & $8.75 E+02$ & $3.24 E-02$ & $5.62 E-03$ & $6.74 E-02$ \\
KR 85 & $6.50 E-02$ & $2.64 E+03$ & $2.35 E-02$ & $0.00 E+00$ & $0.00 E+00$ \\
SR 90 & $2.40 E-02$ & $3.17 E+04$ & $2.29 E-02$ & $1.40 E-02$ & $0.00 E+00$ \\
CS 134 & $3.40 E-01$ & $2.59 E+03$ & $6.72 E-03$ & $1.05 E-02$ & $1.85 E-02$ \\
CS 137 & $2.30 E-02$ & $4.31 E+04$ & $7.68 E-02$ & $9.68 E-01$ & $9.14 E-01$ \\
PU 238 & $7.90 E-03$ & $1.15 E+03$ & $2.50 E-01$ & $1.86 E-04$ & $4.86 E-07$ \\
PU 239 & $2.90 E-05$ & $1.73 E+02$ & $4.08 E-02$ & $3.63 E-05$ & $3.78 E-08$ \\
PU 240 & $1.10 E-04$ & $2.39 E+02$ & $5.66 E-02$ & $5.01 E-05$ & $1.13 E-07$ \\
PU 241 & $4.80 E-02$ & $4.21 E+04$ & $1.92 E-01$ & $7.32 E-05$ & $0.00 E+00$ \\
AM 241 & $1.60 E-03$ & $9.45 E+02$ & $2.31 E-01$ & $1.99 E-04$ & $1.56 E-05$ \\
CM 244 & $3.80 E-02$ & $4.51 E+02$ & $6.17 E-02$ & $2.70 E-04$ & $1.07 E-07$ \\
\hline \\
TOTAL & & & $9.94 E-01$ & $9.99 E-01$ & $9.99 E-01$
\end{tabular}

0.20 PERCENT STRAINS 600. DEGREE $F$

RELATIVE HAZARD INGESTION G.SHINE 
TESTCASE 1

09/17/93 17:32 PAGE 15

RISKIND: OCRLM (2/93)

File: RISKIND.INP

\begin{tabular}{|c|c|c|c|}
\hline MUCLIDE & INVENTORY(Ci) & FRAC-REL & Ci-REL \\
\hline co 60 & 8.75E+02 & $1.83 E-05$ & $1.60 E \cdot 02$ \\
\hline KR 85 & $2.64 E+03$ & $9.90 \varepsilon-03$ & $2.62 E+01$ \\
\hline SR 90 & $3.1 \pi E+04$ & $6.00 E-08$ & $1.91 E-03$ \\
\hline CS 134 & 2.59E+OS & $6.00 E-06$ & $1.56 E-02$ \\
\hline CS 137 & $4.31 E+04$ & $6.00 E-06$ & 2.60E-01 \\
\hline PU 238 & $1.15 E+03$ & $6.00 E-08$ & $6.95 E-05$ \\
\hline PU 239 & $1.73 E+02$ & $6.00 E-08$ & $1.04 E-05$ \\
\hline PU 240 & $2.39 E+02$ & $6.00 E-08$ & $1.44 E-05$ \\
\hline PU 241 & $4.21 E+04$ & $6.00 E-08$ & $2.53 E-03$ \\
\hline NN 241 & $9.45 E+02$ & $6.00 E-08$ & 5.68E-05 \\
\hline Con 244 & $4.51 E+02$ & $6.00 E-08$ & 2.71E-05 \\
\hline
\end{tabular}

SUMURY OF POTENTIAL DOSE CONSECUENCES

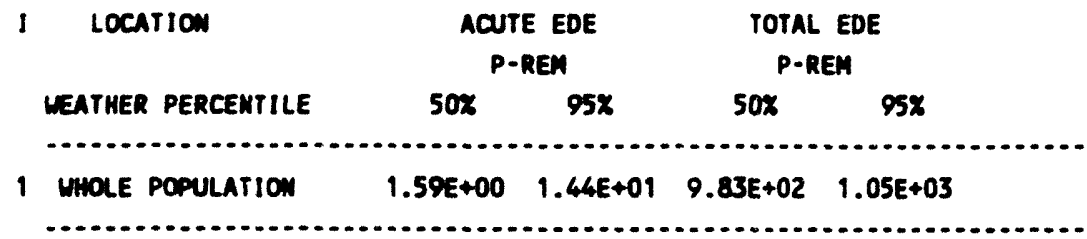

STmmaRY OF POTEMTIAL HEALTH CONSEQUF"CES

ACUTE
FATALITY LOCATION

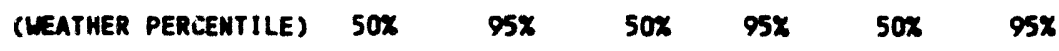

1 mole population $0.00 E+00 \quad 0.00 E+00 \quad 7.86 E-01$ 8.43E-01 $1.97 E-012.11 E-01$




TESTCASEI
RISKIND: OCRIM (2/93)
File: RISKIND.INP

ACCIDENT RESPONSE REGION STRUCTURE RESPONSE WITHIN TEAPERATURE LEVEL WITHIN ACCIDENT SCENARIO PROBABILITY (1/KM) =
6

2.00 PERCENT STRAINS 600. DEGREE $F$

2.33E-07

\begin{tabular}{|c|c|c|c|c|c|}
\hline \multirow[t]{2}{*}{ MUCLIDE } & \multirow[t]{2}{*}{$\operatorname{DCAY}(1 / Y R)$} & \multirow[t]{2}{*}{ CURIE } & \multicolumn{3}{|c|}{ RELATIVE HAZARD } \\
\hline & & & ACUTE & INCEST IOW & G.SHINE \\
\hline co 60 & $1.30 E-01$ & 8.75E+02 & $6.26 E-02$ & $1.12 E-02$ & $1.26 E-01$ \\
\hline KR 85 & $6.50 E-02$ & $2.64 E+03$ & $2.2 \pi-02$ & $0.00 E+00$ & $0.00 E+00$ \\
\hline SR 90 & $2.40 E-02$ & $3.17 E+04$ & $2.22 E-02$ & $1.39 E-02$ & $0.00 E+00$ \\
\hline $\operatorname{cs} 134$ & $3.40 E-01$ & $2.59 e+03$ & $6.51 E-03$ & $1.05 E-02$ & $1.74 E-02$ \\
\hline Cs 137 & 2.30E-02 & $4.31 E+04$ & $7.44 E-02$ & $9.62 E-01$ & $8.56 E \cdot 01$ \\
\hline PU 238 & $7.90 E-03$ & $1.15 E+03$ & $2.42 E-01$ & $1.84 E-04$ & $4.55 E-07$ \\
\hline PU 239 & $2.90 E-05$ & $1.73 E+02$ & $3.95 E-02$ & $3.61 E-05$ & $3.54 E-08$ \\
\hline PU 240 & $1.10 E-04$ & $2.39 E+02$ & $5.48 E-02$ & $4.99 E-05$ & $1.06 E-07$ \\
\hline PU 241 & 4.80E-02 & $4.21 E+04$ & $1.86 E-01$ & $7.28 E-05$ & $0.00 E+00$ \\
\hline NM 241 & $1.60 E-03$ & $9.45 E+02$ & $2.24 E-01$ & $1.98 E-04$ & $1.46 E-05$ \\
\hline CN 244 & $3.80 E-02$ & $4.51 E+02$ & $5.98 E-02$ & $2.69 E-04$ & $1.01 E-07$ \\
\hline
\end{tabular}

TOTAL

9.94E-01

9.99E-01

$1.00 E+00$ 


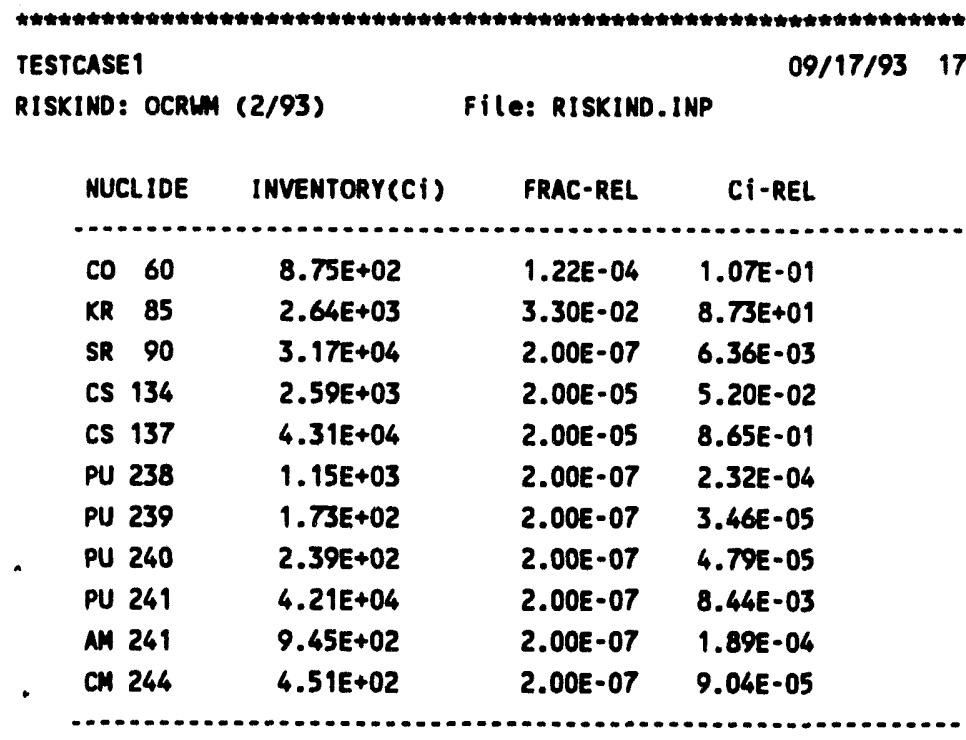

SUMmaRY OF POTENTIAL DOSE CONSEQUENCES

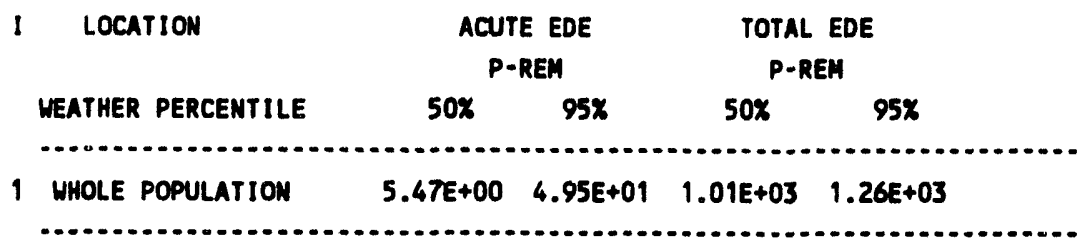

SU:WARY OF POTENTIAL HEALTH CONSEQUENCES

\begin{tabular}{|c|c|c|c|c|c|c|}
\hline \multirow{2}{*}{$\begin{array}{l}\text { I LOCATION } \\
\text { CWEATHER PE }\end{array}$} & \multicolumn{2}{|c|}{$\begin{array}{l}\text { ACUTE } \\
\text { FATALITY }\end{array}$} & \multicolumn{2}{|c|}{$\begin{array}{l}\text { LATENT } \\
\text { FATALITY }\end{array}$} & \multicolumn{2}{|c|}{$\begin{array}{l}\text { GEMETIC } \\
\text { EFFECT }\end{array}$} \\
\hline & $50 x$ & $95 \%$ & $50 \%$ & $95 \%$ & $50 \%$ & $95 x$ \\
\hline
\end{tabular}




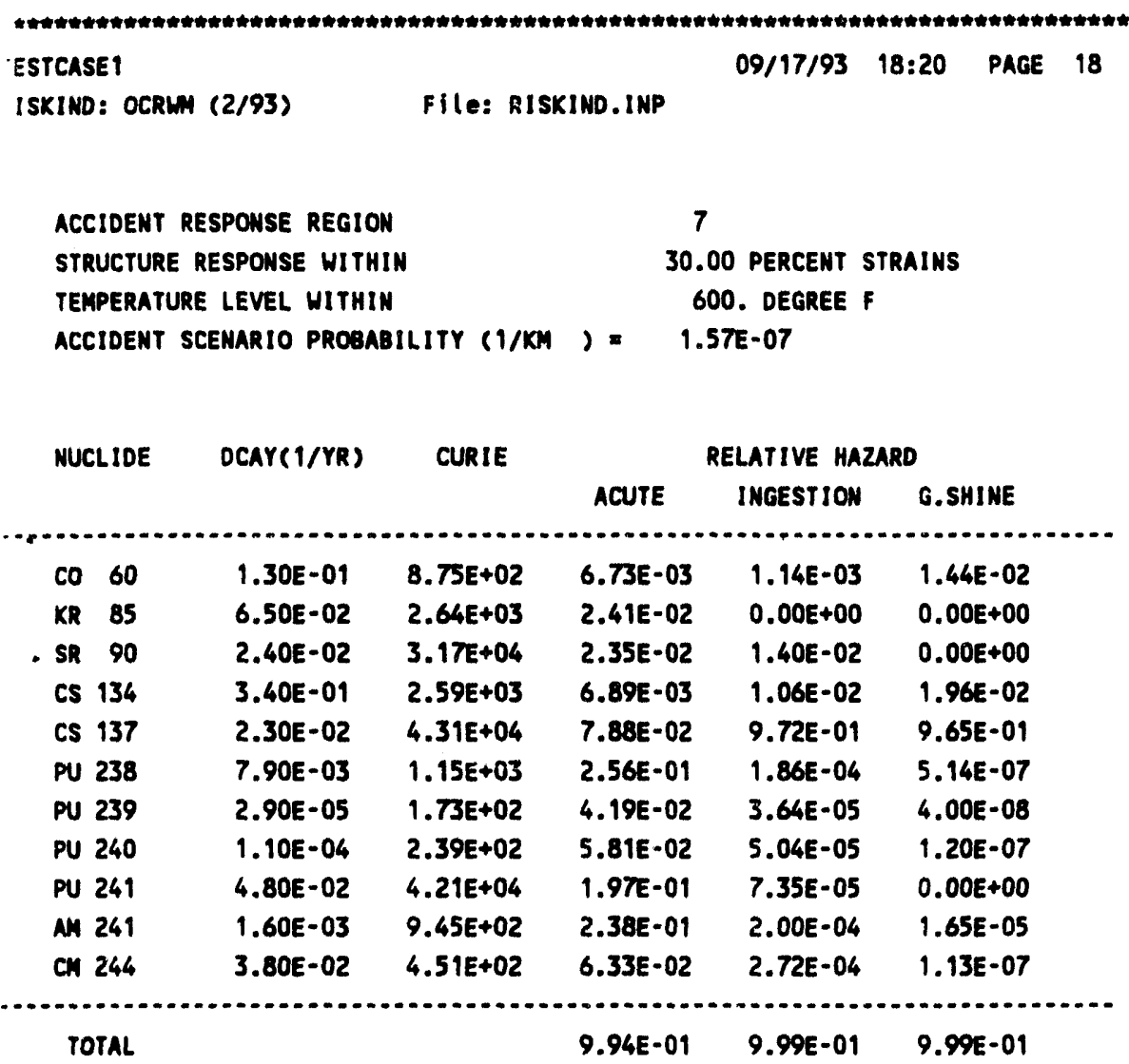




\begin{tabular}{|c|c|c|c|}
\hline \multicolumn{3}{|l|}{ TESTCASE 1} & \multirow[t]{2}{*}{$09 / 17 / 93$} \\
\hline RISKIND: OCRW & $(2 / 93)$ & e: RISKIND & \\
\hline NUCLIDE & INVENTORY(Ci) & FRAC-REL & $\mathrm{CI}$-REL \\
\hline \multicolumn{4}{|l|}{$\cdots$} \\
\hline co 60 & $8.75 E+02$ & $1.23 E-04$ & $1.08 E-01$ \\
\hline KR 85 & $2.64 E+03$ & 3.30E-01 & $8.73 E+02$ \\
\hline SR 90 & $3.17 E+04$ & $2.00 E-06$ & $6.36 E-02$ \\
\hline CS 134 & $2.59 E+03$ & $2.00 E-04$ & $5.20 E-01$ \\
\hline CS 137 & $4.31 E+04$ & $2.00 E-04$ & $8.65 E+00$ \\
\hline PU 238 & $1.15 E+03$ & $2.00 E-06$ & $2.32 E-03$ \\
\hline PU 239 & $1.73 E+02$ & $2.00 E-06$ & $3.46 E-04$ \\
\hline PU 240 & $2.39 E+02$ & $2.00 E-06$ & $4.79 E-04$ \\
\hline PU 241 & $4.21 E+04$ & $2.00 E-06$ & $8.44 E-02$ \\
\hline AN 241 & $9.45 E+02$ & $2.00 E-06$ & $1.89 E-03$ \\
\hline CN 244 & $4.51 E+02$ & $2.00 E-06$ & $9.04 E-04$ \\
\hline
\end{tabular}

SUMmARY OF POTENTIAL DOSE CONSEQUENCES

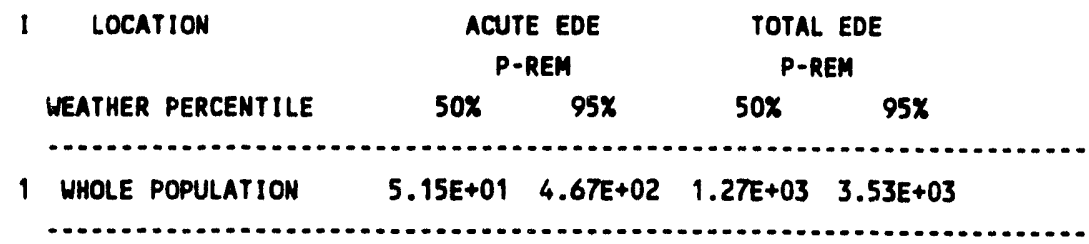

SUMMARY OF POTENTIAL HEALTH CONSEQUENCES

\begin{tabular}{|c|c|c|c|}
\hline LOCATION & $\begin{array}{l}\text { ACUTE } \\
\text { FATALITY }\end{array}$ & $\begin{array}{l}\text { LATENT } \\
\text { FATALITY }\end{array}$ & $\begin{array}{l}\text { GENETIC } \\
\text { EFFECT }\end{array}$ \\
\hline (WEATHER PERCENTILE) & $50 \% \quad 95 x$ & $50 \% \quad 95 \%$ & $50 x \quad 95 x$ \\
\hline
\end{tabular}

1 HHOLE POPULATION $0.00 E+00 \quad 0.00 E+00 \quad 1.02 E+00 \quad 2.82 E+00 \quad 2.54 E-01 \quad 7.05 E-01$ 
ACCIDENT RESPONSE REGION

STRUCTURE RESPONSE EXCEED TEMPERATURE LEVEL WITHIN ACCIDENT SCENARIO PROBABILITY (1/KM
8

30.00 PERCENT STRAINS

600. DEGREE $F$

$=\quad 3.93 \mathrm{E}-14$

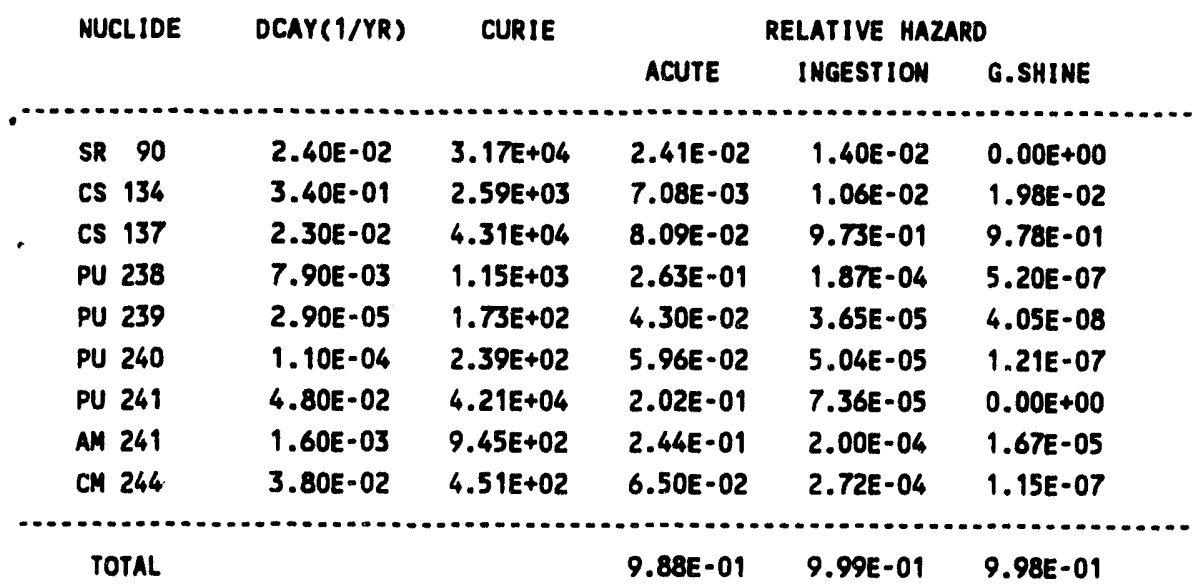




\begin{tabular}{|c|c|c|c|}
\hline \multicolumn{3}{|l|}{ TESTCASE 1} & \multirow[t]{2}{*}{$09 / 17 / 93$} \\
\hline RISKIND: OCRL & $(2 / 93)$ & e: RISKIND & \\
\hline NUCLIDE & INVENTORY (Ci) & FRAC-REL & CI-REL \\
\hline \multicolumn{4}{|l|}{ n. n. } \\
\hline SR 90 & $3.17 E+04$ & $2.00 E-05$ & 6.37E-01 \\
\hline CS 134 & $2.59 E+03$ & $2.00 E-03$ & $5.22 E+00$ \\
\hline Cs 137 & $4.31 E+04$ & $2.00 E-03$ & $8.67 E+01$ \\
\hline PU 238 & $1.15 E+03$ & $2.00 E-05$ & $2.32 E-02$ \\
\hline PU 239 & $1.73 E+02$ & $2.00 E-05$ & $3.47 E-03$ \\
\hline PU 240 & $2.39 E+02$ & $2.00 E-05$ & $4.80 E-03$ \\
\hline PU 241 & $4.21 E+04$ & $2.00 E-05$ & $8.46 E-01$ \\
\hline AM 241 & $9.45 E+02$ & $2.00 E-05$ & $1.90 E-02$ \\
\hline CM 244 & $4.51 E+02$ & $2.00 E-05$ & 9.07E-03 \\
\hline
\end{tabular}

SUMMARY OF POTENTIAL DOSE CONSEQUENCES

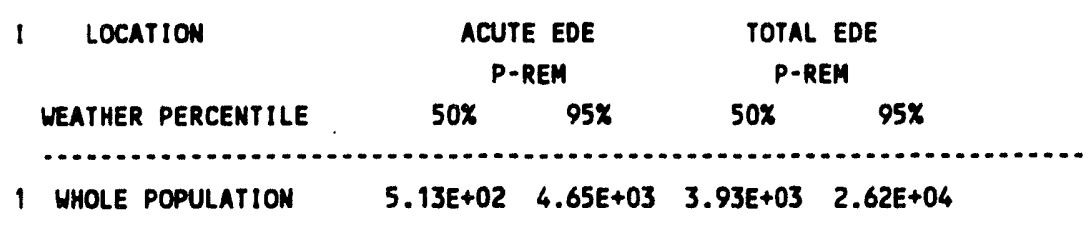

SUMWARY OF POTENTIAL HEALTH CONSEQUENCES

I LOCATION
FATALITY $\begin{gathered}\text { LATENT } \\ \text { FATALITY }\end{gathered}$

1 HHOLE POPULATION $0.00 E+00 \quad 0.00 E+00 \quad 3.14 E+00 \quad 2.10 E+01 \quad 7.85 E-01 \quad 5.25 E+00$ 


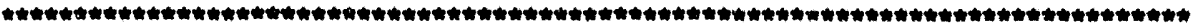

TESTCASE 1

39/17/93 18:54 PAOE 22

RISKIND: OCRWM (2/93) FILE: RISKINO.INP

ACCIDENT RESPONSE REGION STRUCTURE RESPONSE WITHIN TEMPERATURE LEVEL HITHIN

ACCIDENT SCENARIO PROBABILITY (1/KM ) = 2.36E-05

0.20 Percent strains

650. DEGREE F

NUCLIDE

DCAY(1/YR)

CURIE

RELATIVE HAZARD

ACUTE INGESTION G.SHINE

\begin{tabular}{|c|c|c|c|c|c|c|}
\hline co & 60 & $1.30 E-01$ & $8.75 E+02$ & $3.24 E-02$ & $5.62 E-03$ & $6.74 E-02$ \\
\hline KR & 85 & $6.50 \mathrm{E}-02$ & $2.64 E+03$ & $2.35 E-02$ & $0.00 E+00$ & $0.00 E+00$ \\
\hline SR & 90 & $2.40 E-02$ & $3.17 E+04$ & $2.29 E-02$ & $1.40 E-02$ & $0.00 E+00$ \\
\hline CS & 134 & $3.40 E-01$ & $2.59 E+03$ & $6.72 E-03$ & $1.05 E-02$ & $1.85 E-02$ \\
\hline cs & 137 & $2.30 E-02$ & $4.31 E+04$ & $7.68 E-02$ & $9.68 E-01$ & $9.14 E-01$ \\
\hline PU & 238 & $7.90 E-03$ & $1.15 E+03$ & $2.50 E-01$ & $1.86 E-04$ & $4.86 E-07$ \\
\hline PU & 239 & $2.90 E-05$ & $1.73 E+02$ & $4.08 E \cdot 02$ & $3.63 E-05$ & $3.78 \varepsilon-08$ \\
\hline PU & 240 & $1.10 E-04$ & $2.39 E+02$ & $5.66 E-02$ & $5.01 E-05$ & $1.13 E-07$ \\
\hline PU & 241 & $4.80 E-02$ & $4.21 E+04$ & $1.92 E-01$ & $7.32 E-05$ & $0.00 E+00$ \\
\hline$M$ & 241 & $1.60 E-03$ & $9.45 E+02$ & 2.31E-01 & $1.99 E-04$ & $1.56 E-05$ \\
\hline $\mathrm{CM}$ & 244 & $3.80 E-02$ & $4.51 E+02$ & 6.1TE-02 & $2.70 E-04$ & 1.07E-07 \\
\hline
\end{tabular}


RISKIND: OCRLM (2/93)

FIle: RISKIND.INP

$\begin{array}{llll}\text { NUCLIDE } & \text { INVENTORY(Ci) } & \text { FRAC-REL } & \text { CI-REL } \\ \ldots \ldots \ldots \ldots \ldots \ldots \ldots \ldots \ldots \ldots \ldots & \ldots \ldots \ldots \ldots \ldots \\ \text { CO } 60 & 8.75 E+02 & 1.83 E-05 & 1.60 E-02 \\ \text { KR } 85 & 2.64 E+03 & 9.90 E-03 & 2.62 E+01 \\ \text { SR } 90 & 3.17 E+04 & 6.00 E-08 & 1.91 E-03 \\ \text { CS } 134 & 2.59 E+03 & 6.00 E-06 & 1.56 E-02 \\ \text { CS } 137 & 4.31 E+04 & 6.00 E-06 & 2.60 E-01 \\ \text { PU } 238 & 1.15 E+03 & 6.00 E-08 & 6.95 E-05 \\ \text { PU } 239 & 1.73 E+02 & 6.00 E-08 & 1.04 E-05 \\ \text { PU } 240 & 2.39 E+02 & 6.00 E-08 & 1.44 E-05 \\ \text { PU } 241 & 4.21 E+04 & 6.00 E-08 & 2.53 E-03 \\ \text { AM } 241 & 9.45 E+02 & 6.00 E-08 & 5.68 E-05 \\ \text { CM } 244 & 4.51 E+02 & 6.00 E-08 & 2.71 E-05\end{array}$

SUMHARY OF POTENTIAL DOSE CONSEQUENCES

\begin{tabular}{|c|c|c|c|c|}
\hline \multirow{2}{*}{$\begin{array}{l}\text { I LOCATION } \\
\text { MEATHER PERCENTILE }\end{array}$} & \multicolumn{2}{|c|}{$\begin{array}{c}\text { ACUTE EDE } \\
\text { P-REM }\end{array}$} & \multicolumn{2}{|c|}{$\begin{array}{c}\text { TOTAL EDE } \\
\text { P-REM }\end{array}$} \\
\hline & $50 x$ & $95 x$ & $50 x$ & $95 x$ \\
\hline 1 WHOLE POPULATION & $1.59 E+00$ & $1.44 E+01$ & $1.23 E+03$ & $1.31 E+03$ \\
\hline
\end{tabular}

SUMUARY OF POTENTIAL HEALTH CONSEQUENCES

\begin{tabular}{|c|c|c|c|c|c|}
\hline 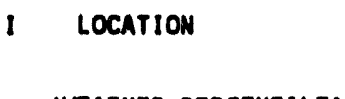 & \multicolumn{2}{|c|}{$\begin{array}{l}\text { ACUTE } \\
\text { FATALITY }\end{array}$} & \multicolumn{2}{|c|}{$\begin{array}{l}\text { LATENT } \\
\text { FATALITY }\end{array}$} & $\begin{array}{l}\text { GENETIC } \\
\text { EFFECT }\end{array}$ \\
\hline (MEATHER PERCENTILE) & $50 x$ & $95 x$ & $50 \%$ & $95 x$ & \\
\hline
\end{tabular}

1 HHOLE POPULATION $\quad 0.00 E+00 \quad 0.00 E+00 \quad 9.88 E-01 \quad 1.04 E+00 \quad 2.47 E-01 \quad 2.61 E-01$ 


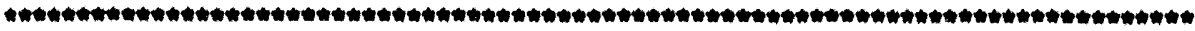

TEstCAse1

09/17/93 19:18 PACE 24

RISKINO: OCRIM (2/93)

PIle: RIBKINO.INP

ACCIOENT RESPONSE REOION

STRUCTURE RESPONSE WITHIN

TEAPERATURE LEVEL MITHIN

10
ACCIDENT SCENARLO PROBABILITY (1/KM) $=3.01 E-07$

2.00 PERCENT STRAIMS

650. DECREE

RELATIVE HAZARD

ACUTE IMGESTIOW O.SHINE

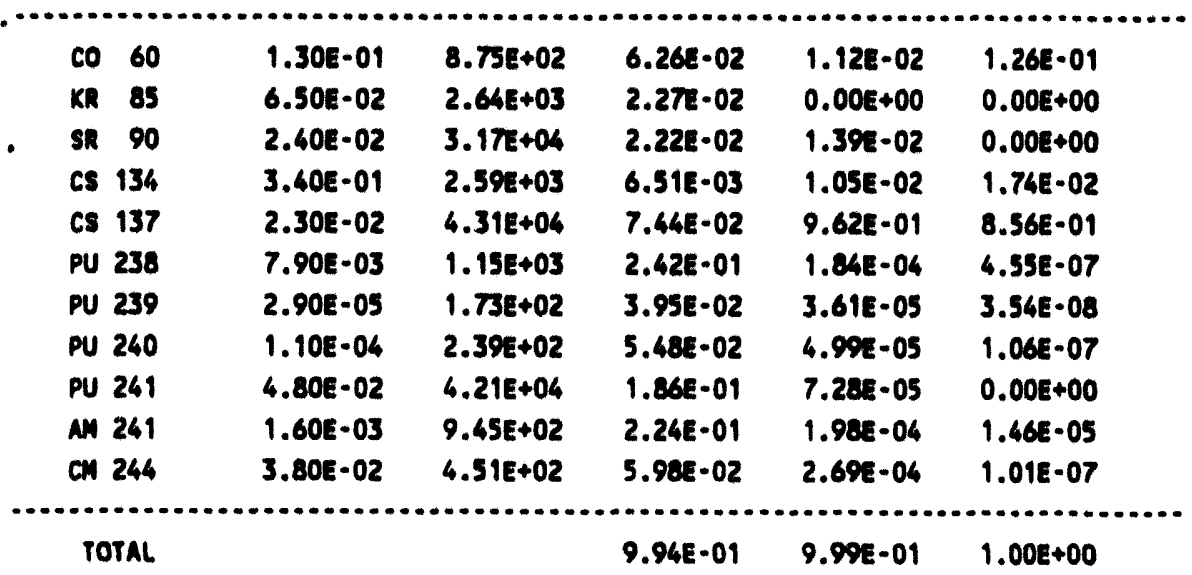




\begin{tabular}{|c|c|c|c|}
\hline \multicolumn{3}{|l|}{ E1 } & \multirow[t]{2}{*}{$09 / 17 / 93$} \\
\hline \multicolumn{2}{|c|}{ ( $\operatorname{OCRLA}(2 / 93)$} & Flles RISKIND.INP & \\
\hline ICLIDE & InVENTOAY(CI) & PRAC-REL & $\mathrm{Cl} \cdot \mathrm{REL}$ \\
\hline 60 & $8.75 E+02$ & $1.22 E-04$ & $1.0 \pi=01$ \\
\hline 85 & $2.648+03$ & $3.308-02$ & $8.73 E+01$ \\
\hline 90 & $3.17 E+04$ & $2.008-07$ & $6.36 t \cdot 03$ \\
\hline ; 134 & $2.59 \%+03$ & $2.008 \cdot 05$ & 5.208 .02 \\
\hline ; 137 & $4.31 E+06$ & $2.008-05$ & $8.65 E .01$ \\
\hline 1238 & $1.15 E+03$ & $2.008-07$ & $2.32 E-04$ \\
\hline J 239 & $1.73 E+02$ & $2.008-07$ & $3.668 \cdot 05$ \\
\hline 1240 & $2.39 e+02$ & $2.008-07$ & $4.79 E \cdot 05$ \\
\hline J 241 & $4.21 E+04$ & $2.008-07$ & $8.448 \cdot 03$ \\
\hline 1261 & $9.45 E+02$ & $2.00 E-07$ & $1.89 \cdot .04$ \\
\hline 1246 & $4.51 E+02$ & $2.008-07$ & $9.04 E \cdot 05$ \\
\hline
\end{tabular}

SUMmarY OF POTENTIAL DOSE CONEEOUENCES

\begin{tabular}{|c|c|c|c|c|}
\hline \multirow{2}{*}{$\begin{array}{l}\text { OCATION } \\
\text { THER PERCENTILE }\end{array}$} & \multicolumn{2}{|c|}{$\begin{array}{c}\text { ACUTE EDE } \\
\text { P-REM }\end{array}$} & \multicolumn{2}{|c|}{$\begin{array}{c}\text { TOTAL EDE } \\
\text { P-REM }\end{array}$} \\
\hline & $50 x$ & $95 x$ & $50 \%$ & $95 x$ \\
\hline OLE POPULATION & $5.4 \pi+00$ & $4.95 E+01$ & $1.26 t+03$ & $1.51 E+03$ \\
\hline
\end{tabular}

SUMmaRY OF POTENTIAL HEALTH CONSEQUENCES

\begin{tabular}{|c|c|c|c|c|c|c|}
\hline LOCATION & \multicolumn{2}{|c|}{$\begin{array}{l}\text { ACUTE } \\
\text { FATALITY }\end{array}$} & \multicolumn{2}{|c|}{$\begin{array}{l}\text { LATENT } \\
\text { FATALITY }\end{array}$} & \multicolumn{2}{|c|}{$\begin{array}{l}\text { GENETIC } \\
\text { EPFECT }\end{array}$} \\
\hline EATHER PERCENTILE) & $50 x$ & $95 x$ & $50 x$ & $95 x$ & $50 x$ & $95 x$ \\
\hline
\end{tabular}


ACCIDENT RESPOWSE RECLOW STRUCTURE RESPOWSE WITHIN TEMPERATURE LEVEL MITHIN ACCIDENT SCENARIO PROBAOILITY (1/KM) :
11

30.00 PERCENT STRAIMS

650. DECREE F

2.03E-07

\begin{tabular}{|c|c|c|c|c|c|}
\hline \multirow[t]{2}{*}{ NUCLIDE } & \multirow[t]{2}{*}{$\operatorname{DCAY}(1 / Y R)$} & \multirow[t]{2}{*}{ CURIE } & \multicolumn{3}{|c|}{ RELATIVE MAZARO } \\
\hline & & & ACUTE & INCESTION & O.SHINE \\
\hline 6060 & $1.30 E-01$ & $8.73 E+02$ & 6.73E-03 & $1.14 E-03$ & $1.44 E-02$ \\
\hline KR 85 & $6.505-02$ & $2.64 E+03$ & $2.41 E-02$ & $0.00 E+00$ & $0.00 E+00$ \\
\hline SR 90 & $2.40 E-02$ & $3.17 E+04$ & $2.35 E-02$ & $1.40 E-02$ & $0.00 \varepsilon+00$ \\
\hline cs 134 & $3.40 E-01$ & $2.5 \%+03$ & $6.89 \cdot 03$ & $1.06 E-02$ & $1.96 E-02$ \\
\hline $\operatorname{cs} 137$ & $2.30 E-02$ & $4.31 E+04$ & $7.88 E-02$ & 9.72E-01 & $9.65 E-01$ \\
\hline PU 238 & $7.90 E-03$ & $1.15 E+03$ & $2.56 E-01$ & $1.864-04$ & $5.14 E \cdot 07$ \\
\hline PU 239 & $2.90 E-05$ & $1.73 E+02$ & $4.19 E-02$ & $3.64 E-05$ & $4.00 E \cdot 08$ \\
\hline PU 240 & $1.105-04$ & $2.39 E+02$ & $5.81 E-02$ & $5.04 E \cdot 05$ & $1.20 E-07$ \\
\hline PU 241 & $4.80 E-02$ & $4.21 E+04$ & 1.97e-01 & $7.35 E-05$ & $0.00 E+00$ \\
\hline AM 241 & $1.60 \varepsilon-03$ & $9.45 E+02$ & $2.38 \varepsilon-01$ & $2.00 E=04$ & $1.65 E-05$ \\
\hline CN 244 & $3.80 E-02$ & $4.51 E+02$ & $6.33 E-02$ & $2.72 E-04$ & $1.13 E-07$ \\
\hline
\end{tabular}


RISKIND: OCRLM (2/93)

File: RISKIND.INP

NUCLIDE INVENTORY(CI) FRAC-REL CI-REL

$\begin{array}{llll}\text { CO } 60 & 8.75 E+02 & 1.23 E-04 & 1.08 E-01 \\ \text { KR } 85 & 2.64 E+03 & 3.30 E-01 & 8.73 E+02 \\ \text { SR } 90 & 3.17 E+04 & 2.00 E-06 & 6.36 E-02 \\ \text { CS } 134 & 2.59 E+03 & 2.00 E-04 & 5.20 E-01 \\ \text { CS } 137 & 4.31 E+04 & 2.00 E-04 & 8.65 E+00 \\ \text { PU } 238 & 1.15 E+03 & 2.00 E-06 & 2.32 E-03 \\ \text { PU } 239 & 1.73 E+02 & 2.00 E-06 & 3.46 E-04 \\ \text { PU } 240 & 2.39 E+02 & 2.00 E-06 & 4.79 E-04 \\ \text { PU } 241 & 4.21 E+04 & 2.00 E-06 & 8.44 E-02 \\ \text { AN } 241 & 9.45 E+02 & 2.00 E-06 & 1.89 E-03 \\ \text { CM } 244 & 4.51 E+02 & 2.00 E-06 & 9.04 E-04\end{array}$

SUMAARY OF POTENTIAL DOSE CONSEQUENCES

I LOCATION

MeATHeR PERCENTILE
ACUTE EDE

P-REM
TOTAL EDE

P-REM

50X 95\%

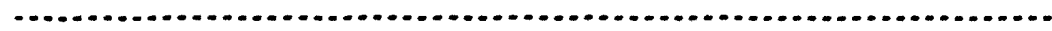

1 HHOLE POPULATION $5.15 E+01 \quad 4.67 E+02 \quad 1.52 E+03 \quad 3.78 E+03$

\section{WhoLe POPULATION}

SUMMARY OF POTENTIAL HEALTH CONSEQUENCES

\begin{tabular}{|c|c|c|c|c|c|c|}
\hline LOCATION & \multicolumn{2}{|c|}{$\begin{array}{l}\text { ACUTE } \\
\text { FATALITY }\end{array}$} & \multicolumn{2}{|c|}{$\begin{array}{l}\text { LATENT } \\
\text { FATALITY }\end{array}$} & \multicolumn{2}{|c|}{$\begin{array}{l}\text { GENETIC } \\
\text { EFFECT }\end{array}$} \\
\hline (MEATHER PERCENTILE) & $50 x$ & $95 x$ & $50 \%$ & $95 x$ & $50 \%$ & $95 \%$ \\
\hline
\end{tabular}

1 HHOLE POPULATION $0.00 E+00 \quad 0.00 E+00 \quad 1.22 E+00 \quad 3.02 E+00 \quad 3.05 E-017.56 E-01$

1 WHOLE POPULATION $\quad 0.00 E+00 \quad 0.00 E+00 \quad 1.22 E+00 \quad 3.02 E+00$ 3.05E-01 7.56E-01 
File: RISKIND.INP

ACCIDENT RESPONSE REGION STRUCTURE RESPONSE EXCEED TEMPERATURE LEVEL WITHIN

ACCIDENT SCEMARIO PROBABILITY (1/KM )
12

30.00 PERCENT STRAINS 650. DEGREE $F$

NUCLIDE DCAY(1/YR) CURIE

RELATIVE hAZARD

ACUTE IMGESTION G.SHINE

$\begin{array}{llllll}\text { SR } 90 & 2.40 E-02 & 3.17 E+04 & 2.41 E-02 & 1.40 E-02 & 0.00 E+00 \\ \text { CS } 134 & 3.40 E-01 & 2.59 E+03 & 7.08 E-03 & 1.06 E-02 & 1.98 E-02 \\ \text { CS } 137 & 2.30 E-02 & 4.31 E+04 & 8.09 E-02 & 9.73 E-01 & 9.76 E-01 \\ \text { PU } 238 & 7.90 E-03 & 1.15 E+03 & 2.63 E-01 & 1.87 E-04 & 5.20 E-07 \\ \text { PU } 239 & 2.90 E-05 & 1.73 E+02 & 4.30 E-02 & 3.65 E-05 & 4.05 E-08 \\ \text { PU } 240 & 1.10 E-04 & 2.39 E+02 & 5.96 E-02 & 5.04 E-05 & 1.21 E-07 \\ \text { PU } 241 & 4.80 E-02 & 4.21 E 404 & 2.02 E-01 & 7.36 E-05 & 0.00 E+00 \\ \text { AM } 241 & 1.60 E-03 & 9.45 E+02 & 2.44 E-01 & 2.00 E-04 & 1.67 E-05 \\ \text { CM } 244 & 3.80 E-02 & 4.51 E+02 & 6.50 E-02 & 2.72 E-04 & 1.15 E-07 \\ \ldots & & & 9.88 E-01 & 9.99 E-01 & 9.98 E-01\end{array}$




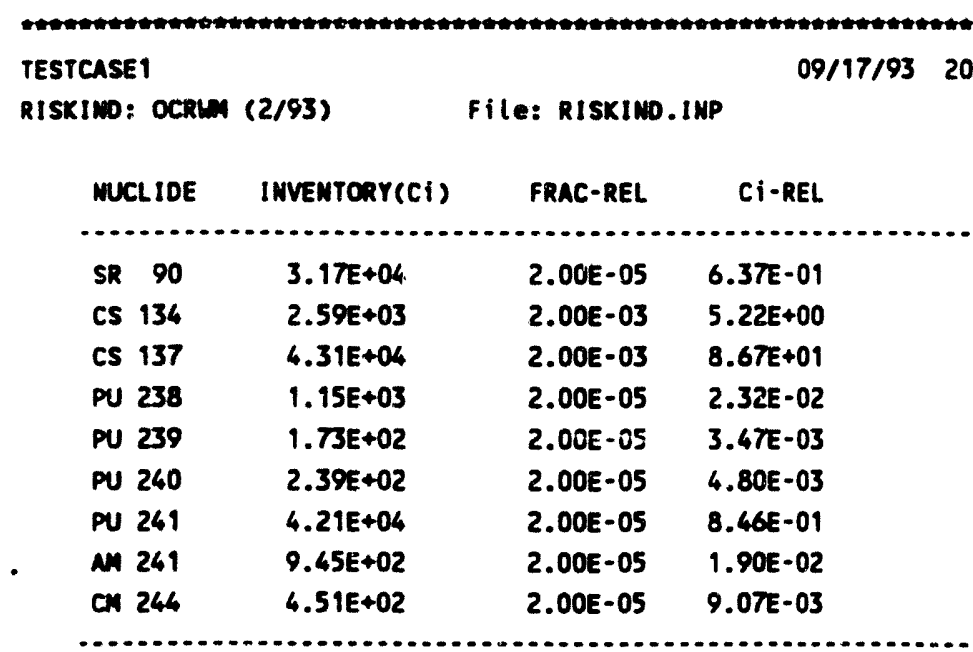

SUmuRY OF POTENTIAL DOSE COASEQUENCES

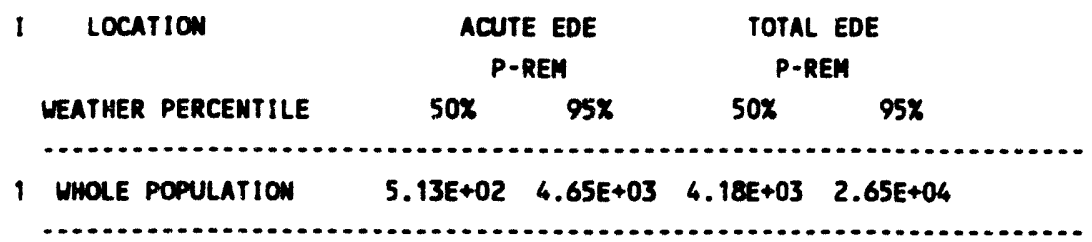

SUmuRY OF POTENTIAL HEALTH CONSEQUENCES

I LOCATION
FATALITY $\begin{gathered}\text { LATENT } \\ \text { FATALITY }\end{gathered}$


ACCIDENT RESPONSE REGION STRUCTURE RESPONSE WITHIN TEKPERATURE LEVEL WITHIN ACCIDENT SCEMARIO PROBABILITY ( $1 / \mathrm{KM})=$
13

0.20 PERCENT STRAINS 1050. DEGREE $F$

1.52E-05

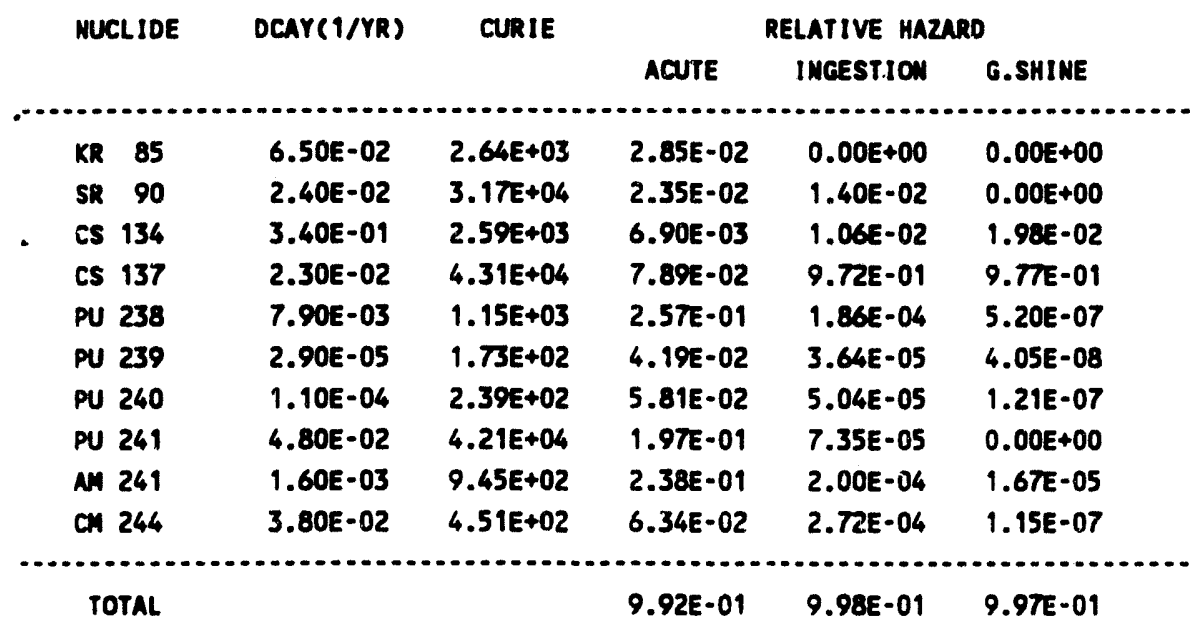




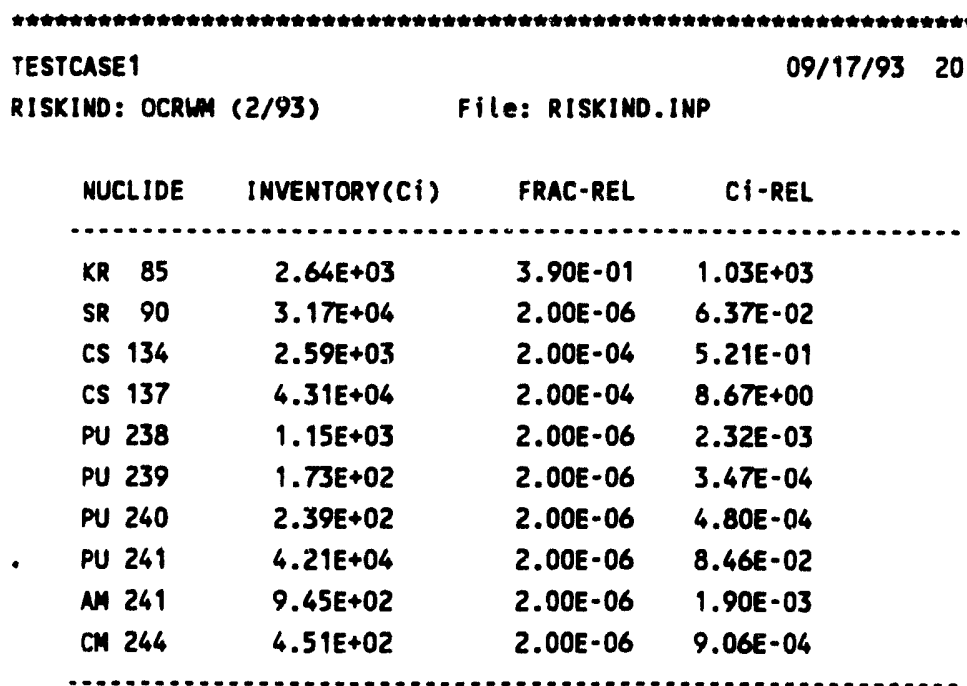

SUMmARY OF POTENTIAL DOSE CONSEQUENCES

\begin{tabular}{|c|c|c|c|c|}
\hline I LOCATION & & & TOT & \\
\hline WEATHER PERCENTILE & $50 \%$ & $95 x$ & $50 x$ & $95 x$ \\
\hline
\end{tabular}

SUMMARY OF POTENTIAL HEALTH CONSEQUENCES

\begin{tabular}{|c|c|c|c|c|c|c|c|}
\hline \multirow[t]{2}{*}{1} & LOCATION & \multicolumn{2}{|c|}{$\begin{array}{l}\text { ACUTE } \\
\text { FATALITY }\end{array}$} & \multicolumn{2}{|c|}{$\begin{array}{l}\text { LATENT } \\
\text { FATALITY }\end{array}$} & \multicolumn{2}{|c|}{$\begin{array}{l}\text { GENETIC } \\
\text { EFFECT }\end{array}$} \\
\hline & (MEATHER PERCENTILE) & $50 \%$ & $95 x$ & $50 \%$ & $95 x$ & $50 \%$ & $95 x$ \\
\hline
\end{tabular}


File: RISKIND.INP

ACCIDENT RESPONSE REGION STRUCTURE RESPONSE WITHIN TEMPERATURE LEVEL WITHIN ACCIDENT SCEMARIO PROBABILITY (1/KM ) =
14

2.00 PERCENT STRAINS 1050. DEGREE $F$

1.59E-07

HUCLIDE DCAY(1/YR) CURIE

RELATIVE HAZARD

ACUTE INGESTION G.SHINE

CO $60 \quad 1.30 E-01 \quad 8.75 E+02 \quad 6.70 E-03 \quad 1.14 E-03 \quad 1.44 E-02$

KR 85

$1.30 E-01$

$2.64 E+03$

2.83E-02

$0.00 E+00$

$0.00 E+00$

SR 90

2.40E-02

$3.17 E+04$

2.34E-02

$1.40 E-02$

$0.00 E+00$

CS 134

3.40E-01

$2.59 E+03$

6.86E-03

1.06E-02

$1.96 E-02$

CS 137

2.30E-02

$4.31 E+04$

7.84E-02

9.71E-01

9.65E-01

PU 238

7.90E-03

$1.15 E+03$

2.55E-01

1.86E-04

5.14E-07

PU 239

2.90E-05

1.73E+02

4.17E-02

3.64E-05

4.00E-08

PU 240

$1.10 E-04$

2.39E+02

5.78E-02

5.03E-05

1.20E-07

PU 241

4.80E-02

4.21E+04

1.96E-01

7.35E-05

$0.00 E+00$

AN 241

1.60E-03

$9.45 E+02$

2.36E-01

2. 00E-04

1.65E-05

CM 244

3.80E-02

4.51E+02

6.30E-02

2.71E-04

1.13E-07 


NUCLIDE INVENTORY(Ci) FRAC-REL Ci-REL

$\begin{array}{llll}\text { CO } 60 & 8.75 E+02 & 1.23 E-04 & 1.08 E-01 \\ \text { KR } 85 & 2.64 E+03 & 3.90 E-01 & 1.03 E+03 \\ \text { SR } 90 & 3.17 E+04 & 2.00 E-06 & 6.36 E-02 \\ \text { CS } 134 & 2.59 E+03 & 2.00 E-04 & 5.21 E-01 \\ \text { CS } 137 & 4.31 E+04 & 2.00 E-04 & 8.66 E+00 \\ \text { PU } 238 & 1.15 E+03 & 2.00 E-06 & 2.32 E-03 \\ \text { PU } 239 & 1.73 E+02 & 2.00 E-06 & 3.46 E-04 \\ \text { PU } 240 & 2.39 E+02 & 2.00 E-06 & 4.80 E-04 \\ \text { PU } 241 & 4.21 E+04 & 2.00 E-06 & 8.45 E-02 \\ \text { AM } 241 & 9.45 E+02 & 2.00 E-06 & 1.90 E-03 \\ \text { CM } 244 & 4.51 E+02 & 2.00 E-06 & 9.05 E-04\end{array}$

SUMMARY OF POTENTIAL DOSE CONSEQUENCES

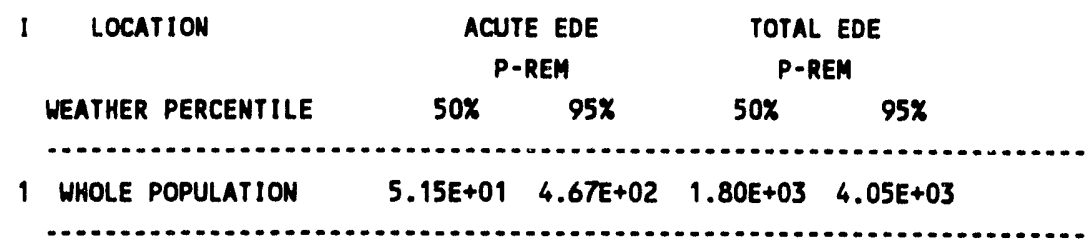

SUMARY OF POTENTIAL HEALTH CONSEQUENCES

\begin{tabular}{|c|c|c|c|c|c|c|}
\hline \multirow{2}{*}{$\begin{array}{l}\text { LOCATION } \\
\text { (WEATHER PERCENTILE) }\end{array}$} & \multicolumn{2}{|c|}{$\begin{array}{l}\text { ACUTE } \\
\text { FATALITY }\end{array}$} & \multicolumn{2}{|c|}{$\begin{array}{l}\text { LATENT } \\
\text { FATALITY }\end{array}$} & \multicolumn{2}{|c|}{$\begin{array}{l}\text { GENETIC } \\
\text { EFFECT }\end{array}$} \\
\hline & $50 x$ & $95 x$ & $50 \%$ & $95 x$ & $50 x$ & $95 x$ \\
\hline
\end{tabular}



ACCIDENT RESPONSE REGION STRUCTURE RESPONSE WITHIN TEMPERATURE LEVEL MITHIN ACCIDENT SCEMARIO PROBABILITY (1/KM)
30.00 PERCENT STRAINS 1050. DEGREE $F$
$1.08 E * 07$

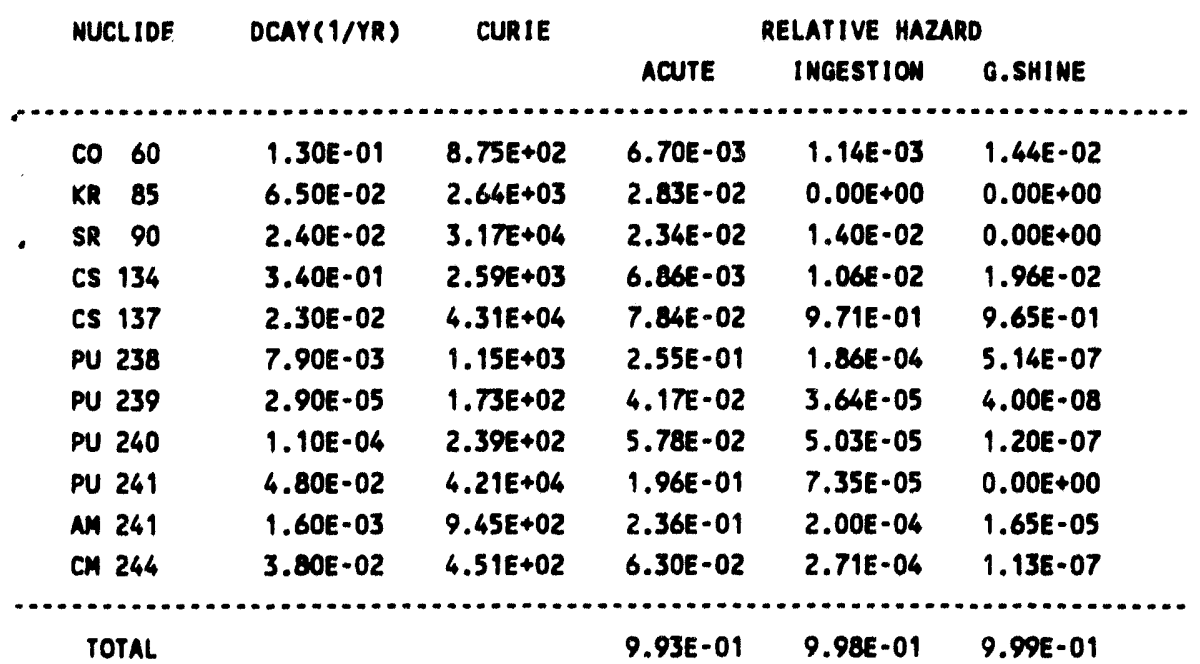




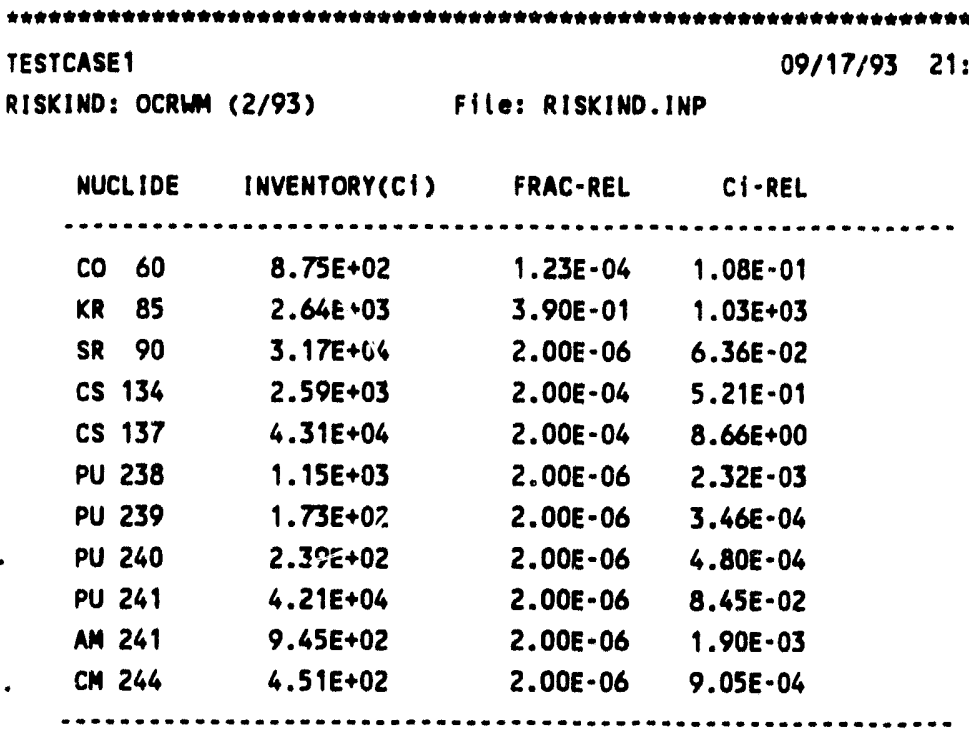

SUMMARY OF POTENTIAL DOSE CONSEQUENCES

\begin{tabular}{|c|c|c|c|c|}
\hline LOCATION & & $\begin{array}{l}\text { EDE } \\
\text { EM }\end{array}$ & $\begin{array}{r}\text { TOTAL } \\
P-R\end{array}$ & $\begin{array}{l}\text { EDE } \\
\text { M }\end{array}$ \\
\hline WEATHER PERCENTILE & $50 \%$ & $95 x$ & $50 \%$ & $95 \%$ \\
\hline WHOLE POPULATION & $5.15 E+01$ & $4.67 E+02$ & $1.82 E+03$ & $4.07 E+03$ \\
\hline
\end{tabular}

SUMMARY OF POTENTIAL HEALTH CONSEQUENCES

\begin{tabular}{|c|c|c|c|c|c|c|c|}
\hline \multicolumn{2}{|c|}{ LOCATION } & \multicolumn{2}{|c|}{$\begin{array}{l}\text { ACUTE } \\
\text { FATALITY }\end{array}$} & \multicolumn{2}{|c|}{$\begin{array}{l}\text { LATENT } \\
\text { FATALITY }\end{array}$} & \multicolumn{2}{|c|}{$\begin{array}{l}\text { GENETIC } \\
\text { EFFECT }\end{array}$} \\
\hline (WEATHER & PERCENTILE) & $50 \%$ & $95 x$ & $50 \%$ & $95 x$ & $50 x$ & $95 x$ \\
\hline
\end{tabular}

1 WHOLE POPULATION $\quad 0.00 E+00 \quad 0.00 E+00 \quad 1.45 E+00 \quad 3.26 E+00 \quad 3.64 E-01 \quad 8.15 E-01$ 

ACCIDENT RESPONSE REGION
16
STRUCTURE RESPONSE EXCEED
30.00 PERCENT STRAIMS
TEMPERATURE LEVEL WITHIN 1050. DEGREE
ACCIDENT SCENARIO PROBABILITY $(1 / \mathrm{KM})=7.68 E-16$

NUCLIDE DCAY(1/YR) CURIE

RELATIVE HAZARO

ACUTE INGESTION G.SHINE

\begin{tabular}{llllll} 
SR 90 & $2.40 E-02$ & $3.17 E+04$ & $2.41 E-02$ & $1.40 E-02$ & $0.00 E+00$ \\
CS 134 & $3.40 E-01$ & $2.59 E+03$ & $7.07 E-03$ & $1.06 E-02$ & $1.98 E-02$ \\
CS 137 & $2.30 E-02$ & $4.31 E+04$ & $8.08 E-02$ & $9.72 E-01$ & $9.78 E-01$ \\
PU 238 & $7.90 E-03$ & $1.15 E+03$ & $2.63 E-01$ & $1.86 E-04$ & $5.20 E-07$ \\
PU 239 & $2.90 E-05$ & $1.73 E+02$ & $4.30 E-02$ & $3.64 E-05$ & $4.05 E-08$ \\
PU 240 & $1.10 E-04$ & $2.39 E+02$ & $5.95 E-02$ & $5.04 E-05$ & $1.21 E-07$ \\
PU 241 & $4.80 E-02$ & $4.21 E+04$ & $2.02 E-01$ & $7.35 E-05$ & $0.00 E+00$ \\
AM 241 & $1.60 E-03$ & $9.45 E+02$ & $2.44 E-01$ & $2.00 E-04$ & $1.67 E-05$ \\
CH 244 & $3.80 E-02$ & $4.51 E+02$ & $6.50 E-02$ & $2.72 E-04$ & $1.15 E-07$ \\
\hline
\end{tabular}




\begin{tabular}{|c|c|c|c|}
\hline NUCLIDE & INVENTORY(CI) & FRAC-REL & CI-REL \\
\hline SR 90 & $3.17 E+04$ & $2.00 E-05$ & $6.38 E-01$ \\
\hline Cs 134 & $2.59 \varepsilon+03$ & $2.00 E-03$ & $5.22 E+00$ \\
\hline Cs 137 & $4.31 E+04$ & $2.00 E \cdot 03$ & $8.68 E+01$ \\
\hline PU 238 & $1.15 E+03$ & $2.00 \mathrm{E}-05$ & $2.32 E-02$ \\
\hline PU 239 & 1.73E+02 & $2.00 E-05$ & $3.47 E-03$ \\
\hline PU 240 & $2.39 E+02$ & $2.00 E-05$ & $4.81 E-03$ \\
\hline PU 241 & $4.21 E+04$ & $2.00 E-05$ & $8.4 \pi-01$ \\
\hline NN 241 & $9.45 E+02$ & $2.00 E-05$ & $1.90 E-02$ \\
\hline CH 244 & $4.51 E+02$ & $2.00 E-05$ & $9.07 E-03$ \\
\hline
\end{tabular}

SUMmARY OF POTENTIAL DOSE CONSEQUENCES

\begin{tabular}{|c|c|c|c|c|}
\hline \multirow{2}{*}{$\begin{array}{l}\text { LOCATION } \\
\text { MEATHER PERCENTILE }\end{array}$} & \multicolumn{2}{|c|}{$\begin{array}{c}\text { ACUTE EDE } \\
\text { P-REM }\end{array}$} & \multicolumn{2}{|c|}{$\begin{array}{c}\text { TOTAL EDE } \\
\text { P-REM }\end{array}$} \\
\hline & $50 x$ & $95 x$ & $50 x$ & $95 \%$ \\
\hline WHOLE POPULATION & $5.13 E+02$ & $4.65 E+03$ & $4.47 E+03$ & $2.68 E+04$ \\
\hline
\end{tabular}

SUMMARY OF POTENTIAL HEALTH CONSEOUENCES

\begin{tabular}{|c|c|c|c|c|c|c|}
\hline LOCATION & \multicolumn{2}{|c|}{$\begin{array}{l}\text { ACUTE } \\
\text { FATALITY }\end{array}$} & \multicolumn{2}{|c|}{$\begin{array}{l}\text { LATENT } \\
\text { FATALITY }\end{array}$} & \multicolumn{2}{|c|}{$\begin{array}{l}\text { GENETIC } \\
\text { EFFECT }\end{array}$} \\
\hline (MEATHER PERCENTILE) & $50 x$ & $95 x$ & $50 \%$ & $95 x$ & $50 x$ & $95 \%$ \\
\hline
\end{tabular}


ACCIDENT RESPONBE RECION STRUCTURE RESPONSE WITHIM TEMPERATURE LEVEL EXCEED ACCIDENT SCEMARIO PROBABILITY (1/KM ) =
17

0.20 percent straims

1050. DECREE F

$9.572 \cdot 06$

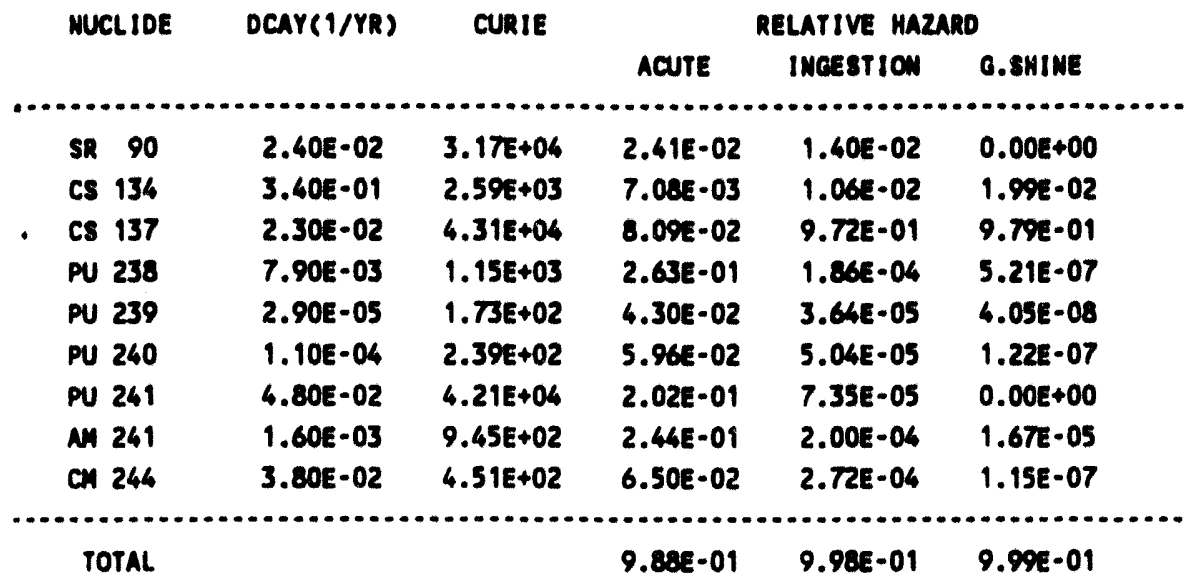




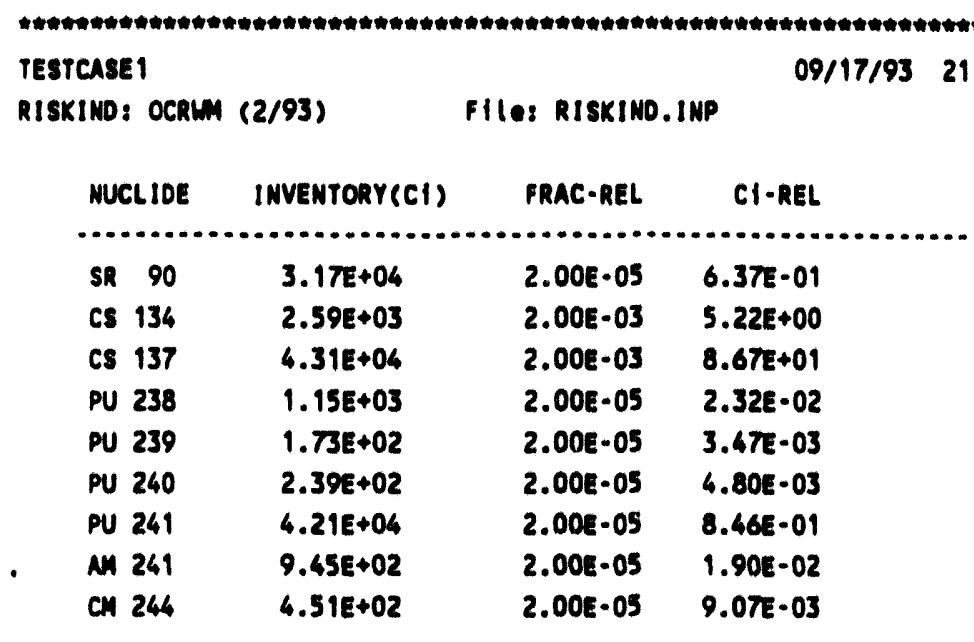

SUMARY OF POTENTIAL DOSE CONSEQUENCES

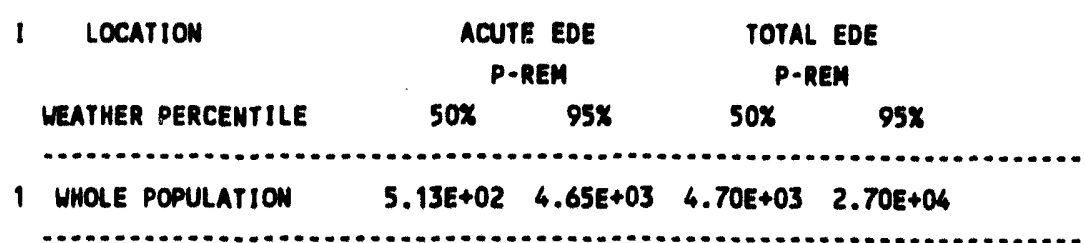

SUMMARY OF POTENTIAL HEALTH CONSEOUENCES

\begin{tabular}{|c|c|c|c|c|c|c|c|}
\hline \multirow[t]{2}{*}{ I } & LOCATION & \multicolumn{2}{|c|}{$\begin{array}{c}\text { ACUTE } \\
\text { FATALITY }\end{array}$} & \multicolumn{2}{|c|}{$\begin{array}{l}\text { LATENT } \\
\text { FATALITY }\end{array}$} & \multicolumn{2}{|c|}{$\begin{array}{l}\text { GENETIC } \\
\text { EFFECT }\end{array}$} \\
\hline & (WEATHER PERCENTILE) & $50 x$ & $95 x$ & $50 x$ & $95 x$ & $50 x$ & $95 x$ \\
\hline
\end{tabular}




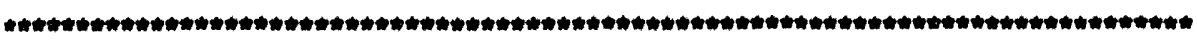

TESTCASE 1

09/17/93 21:47 PAGE 40

RISKIND: OCRLW (2/93)

FIle: RISKIND.INP

ACCIDENT RESPONSE RECION STRUCTURE RESPONSE WITHIN TEMPERATURE LEVEL EXCEED ACCIDENT SCEMARIO PROBABILITY (1/KM ) :
18

2.00 PERCENT STRAIMS

1050. DECREE F

$7.20 E-08$

RELATIVE HAZARO INEESTION G.SHIME

$\begin{array}{llllll}\text { SR } 90 & 2.40 E-02 & 3.17 E+04 & 2.41 E-02 & 1.40 E-02 & 0.00 E+00 \\ \text { CS } 134 & 3.40 E-01 & 2.59 E+03 & 7.07 E-03 & 1.06 E-02 & 1.98 E-02 \\ \text { CS } 137 & 2.30 E-02 & 4.31 E+04 & 8.08 E-02 & 9.72 E-01 & 9.70 E-01 \\ \text { PU } 238 & 7.90 E-03 & 1.15 E+03 & 2.63 E-01 & 1.86 E-04 & 5.20 E-07 \\ \text { PU } 239 & 2.90 E-05 & 1.73 E+02 & 4.30 E-02 & 3.64 E-05 & 4.05 E-08 \\ \text { PU } 240 & 1.10 E-04 & 2.39 E+02 & 5.95 E-02 & 5.04 E-05 & 1.21 E-07 \\ \text { PU } 241 & 4.80 E-02 & 4.21 E+04 & 2.02 E-01 & 7.35 E-05 & 0.00 E+00 \\ \text { NU } 241 & 1.60 E-03 & 9.45 E+02 & 2.44 E-01 & 2.00 E-04 & 1.67 E-05 \\ \text { CH } 246 & 3.80 E-02 & 4.51 E+02 & 6.50 E-02 & 2.72 E-04 & 1.15 E-07\end{array}$

TOTAL

9.88E-01 9.98E-01 9.98E-01 


\begin{tabular}{|c|c|c|c|}
\hline \multicolumn{3}{|l|}{ TESTCASE 1} & \multirow[t]{2}{*}{$09 / 17 / 93$} \\
\hline RISKIND: OCRI & (2/93) & le: RISKIND & \\
\hline NUCLIDE & INVENTORY(CI) & FRAC-REL & CI-REL \\
\hline \multicolumn{4}{|c|}{ (n) } \\
\hline SR 90 & $3.17 E+04$ & $2.00 E-05$ & $6.38 E-01$ \\
\hline $\operatorname{CS} 134$ & $2.59 E+03$ & $2.00 E-03$ & $5.22 E+00$ \\
\hline Cs 137 & $4.31 E+04$ & $? .00 E-03$ & $8.68 E+01$ \\
\hline PU 238 & $1.15 E+03$ & $2.00 E-05$ & $2.32 E-02$ \\
\hline PU 239 & $1.73 E+02$ & $2.00 E-05$ & $3.47 E-03$ \\
\hline PU 240 & $2.39 \varepsilon+02$ & $2.00 E-05$ & $4.81 E-03$ \\
\hline PU 241 & $4.21 E+04$ & $2.00 E-05$ & $8.47 E-01$ \\
\hline NM 241 & $9.45 E+02$ & $2.00 E-05$ & $1.90 E-02$ \\
\hline CM 244 & $4.51 E+02$ & $2.00 E-05$ & $9.07 \mathrm{E} \cdot 03$ \\
\hline
\end{tabular}

SUMmARY OF POTENTIAL DOSE CONSEQUENCES

\begin{tabular}{|c|c|c|c|c|}
\hline I LOCATION & & $\begin{array}{l}\text { EDE } \\
\text { EEM }\end{array}$ & TOT & \\
\hline WEATHER PERCENTILE & $50 x$ & $95 x$ & $50 \%$ & $95 \%$ \\
\hline
\end{tabular}

SUMmarY OF POTENTIAL HEALTH CONSEQUENCES

\begin{tabular}{|c|c|c|c|c|c|c|}
\hline \multirow[b]{2}{*}{ 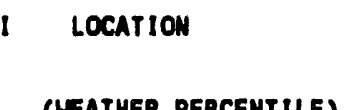 } & \multicolumn{2}{|c|}{$\begin{array}{l}\text { ACUTE } \\
\text { FATALITY }\end{array}$} & \multicolumn{2}{|c|}{$\begin{array}{c}\text { LATENT } \\
\text { FATALITY }\end{array}$} & \multicolumn{2}{|c|}{$\begin{array}{l}\text { GENETIC } \\
\text { EFFECT }\end{array}$} \\
\hline & $50 x$ & $95 x$ & $50 x$ & $95 x$ & $50 x$ & $95 \%$ \\
\hline
\end{tabular}


ACCIDENT RESPONSE REOION STRUCTURE RESPONSE WITHIN TEMPERATURE LEVEL EXCEED ACCIDENT SCENARIO PROBABILITY (1/KM) =
19

30.00 PERCENT STRAINS 1050. DEGREE F

4.87E-08

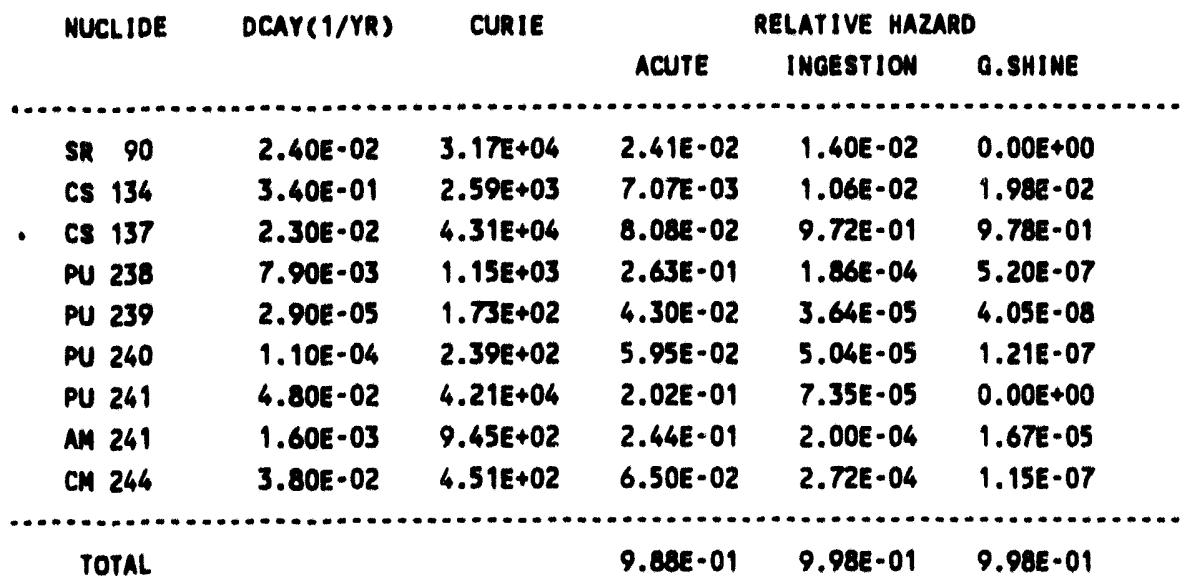




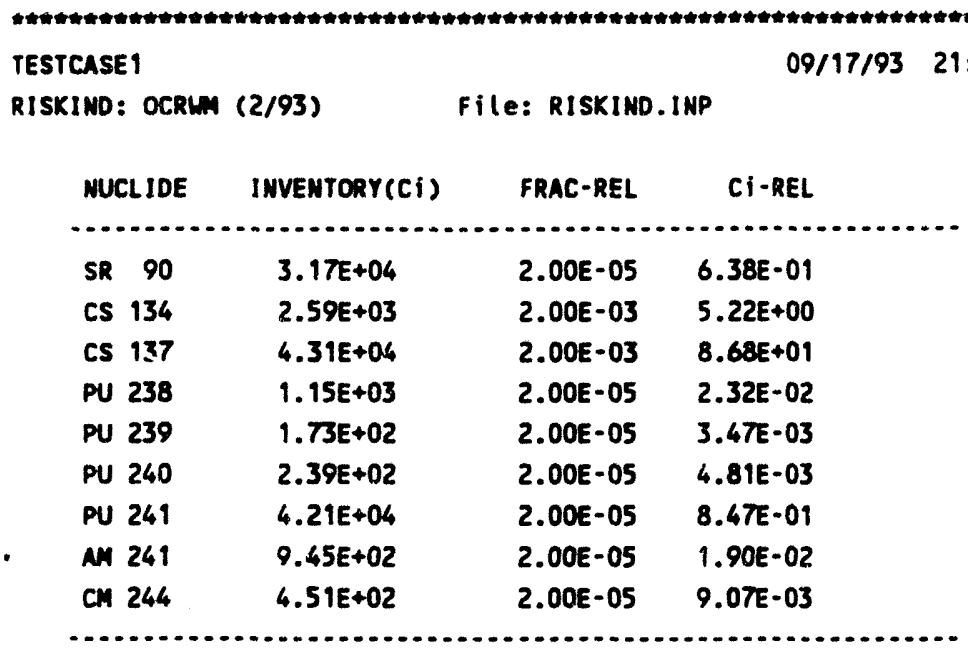

SUMARY OF POTENTIAL DOSE CONSEQUENCES

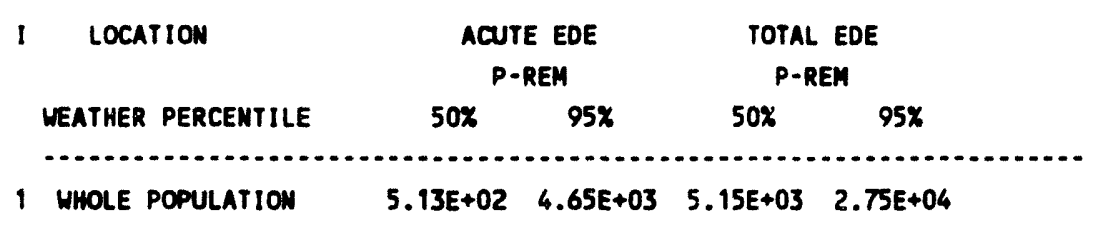

SUMUARY OF POTENTIAL HEALTH CONSEQUENCES

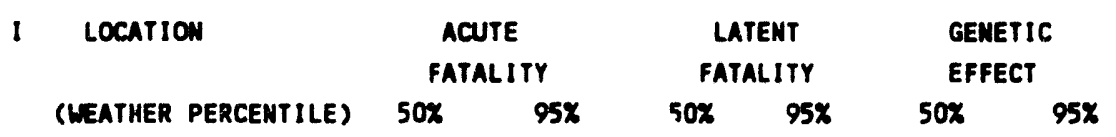

1 WHOLE POPULATION $\quad 0.00 E+00 \quad 0.00 E+00 \quad 4.12 E+00 \quad 2.20 E+01 \quad 1.03 E+00 \quad 5.50 E+00$ 
10

TESTCASE 1

09/17/93 22:06 PAGE 44

RISKIND: OCRUM (2/93)

File: RISKIND.INP

ACCIDENT RESPONSE REGION STRUCTURE RESPONSE EXCEED TEMPERATURE LEVEL EXCEED ACCIDENT SCEMARIO PROBABILITY

MUCLIDE DCAY(1/YR) CURIE

RELATIVE HAZARD

\begin{tabular}{|c|c|c|c|c|c|}
\hline SR 90 & $2.40 E-02$ & $3.17 E+04$ & $2.41 E-02$ & $1.40 E-02$ & $0.00 E+00$ \\
\hline CS 134 & $3.40 E-01$ & $2.59 E+03$ & 7.07E-03 & $1.06 E-02$ & $1.98 E-02$ \\
\hline CS 137 & $2.30 E-02$ & $4.31 E+04$ & $8.08 E-02$ & 9.72E-01 & $9.78 E-01$ \\
\hline PU 238 & $7.90 E-03$ & $1.15 E+03$ & $2.63 E-01$ & $1.86 E-04$ & $5.20 E-07$ \\
\hline PU 239 & 2.90E-05 & $1.73 E+02$ & $4.30 E-02$ & $3.64 E-05$ & $4.05 E-08$ \\
\hline PU 240 & $1.10 E-04$ & $2.39 E+02$ & $5,95 E-02$ & $5.04 E-05$ & $1.21 E-07$ \\
\hline PU 241 & $4.80 E-02$ & $4.21 E+04$ & $2.02 E-01$ & $7.35 E-05$ & $0.00 E+00$ \\
\hline AM 241 & $1.60 E-03$ & $9.45 E+02$ & $2.44 E-01$ & $2.00 E-04$ & $1.67 E-05$ \\
\hline CM 244 & $3.80 E-02$ & $4.51 E+02$ & $6.50 E-02$ & $2.72 E-04$ & $1.15 E-07$ \\
\hline
\end{tabular}

20

30.00 PERCENT STRAINS 1050. DEGREE $F$

$1.00 E-16$ 


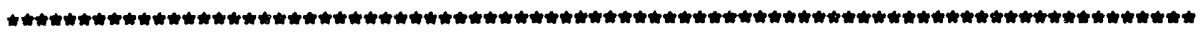

TESTCASE 1

RISKIND: OCRIM (2/93)

File: RISKIND.INP

09/17/93 22:06 PAGE 45

\begin{tabular}{|c|c|c|c|}
\hline NUCLIDE & INVENTORY (Ci) & FRAC-REL & Ci-REL \\
\hline SR 90 & $3.17 E+04$ & $2.00 E-05$ & $6.38 E-01$ \\
\hline CS 134 & $2.59 E+03$ & $2.00 E-03$ & $5.22 E+00$ \\
\hline CS 137 & $4.31 E+04$ & $2.00 \mathrm{E}-03$ & $8.68 E+01$ \\
\hline PU 238 & $1.15 E+03$ & $2.00 E-05$ & $2.32 E-02$ \\
\hline PU 239 & $1.73 E+02$ & $2.00 E-05$ & $3.47 \mathrm{E}-03$ \\
\hline PU 240 & $2.39 E+02$ & $2.00 E-05$ & $4.81 E-03$ \\
\hline PU 241 & $4.21 E+04$ & $2.00 E-05$ & 8.47E-01 \\
\hline AM 241 & $9.45 E+02$ & $2.00 E-05$ & $1.90 E-02$ \\
\hline CM 244 & $4.51 E+02$ & $2.00 E-05$ & $9.07 E-03$ \\
\hline
\end{tabular}

SUMMARY OF POTENTIAL DOSE CONSEQUENCES

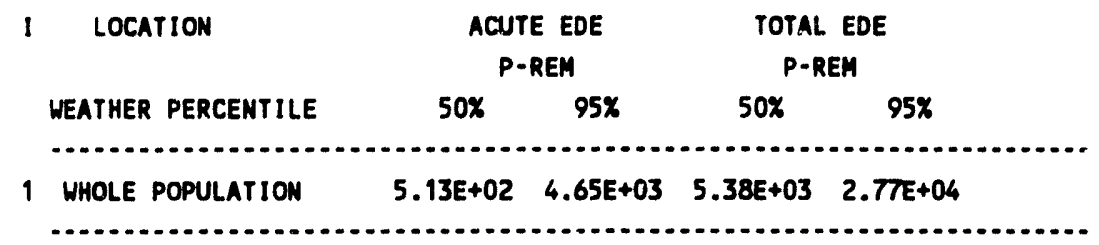

SUMMARY OF POTENTIAL HEALTH CONSEQUENCES

\begin{tabular}{|c|c|c|c|c|c|c|}
\hline LOCATION & \multicolumn{2}{|c|}{$\begin{array}{l}\text { ACUTE } \\
\text { FATALITY }\end{array}$} & \multicolumn{2}{|c|}{$\begin{array}{l}\text { LATENT } \\
\text { FATALITY }\end{array}$} & \multicolumn{2}{|c|}{$\begin{array}{l}\text { GENETIC } \\
\text { EFFECT }\end{array}$} \\
\hline (WEATHER PERCENTILE) & $50 \%$ & $95 \%$ & $50 \%$ & $95 \%$ & $50 \%$ & $95 \%$ \\
\hline
\end{tabular}

SUYWARY PROBABILITY WEIGHTED DOSE RISKS

( $95 \%$ WEATHER )

LCCATION
P-REM EDE
1 WHOLE POPULATION
P-REM

SUMMARY PROBABILITY WEIGHTED HEALTH RISKS

I LOCATION ACUTE LATENT GENETIC

FATALITY FATALITY EFFECT

1 WHOLE POPULATION $5.62 E-03 \quad 2.19 E-02 \quad 5.49 E-03$




\begin{abstract}
APPENDIX C
This RADTRAN 4 sample problem was the second in a series of problems. This particular problem was identical to the initial problem in every way except for the number of kilometers the SST traveled. This was increased from 629.5 to 10000 to determine consistency. This sample problem considers both accident conditions and incident-free transportation analysis. No specific route was intended - only that each population zone (rural, suburban, and urban) was analyzed to include a stopover.

The first 9 pages of the sample problem output outline the input parameters. To achieve the neatness in the format, the original file was transported to a word processor and cleaned up. For this problem, 2 isotopes were chosen: PU-239 and PU-240 with only one isotope group for each. A total of 8 accident-severity categories were selected (as opposed to 20 for the RISKIND problem). A total of 10 radial distances to be used in the nondispersal accident analysis and 18 downwind dose and deposition areas to be used in the dispersal accident analysis were chosen. Also, user-supplied time-integrated concentrated isopleths and areas were employed. This problem models one SST truck shipment of plutonium oxide containing 54 packages, having a $1.5 \mathrm{mrem} / \mathrm{hr}$ dose rate $1 \mathrm{~m}$ from the shipment, and a $100 \%$ gamma dose rate, all over a distance of $10,000 \mathrm{~km}$. The program default for the cask is used: a present generation spent fuel cask. Separate risk values were entered for each population zone.

Page 10 contains the regulatory check messages performed by the code. Pages 10 through 16 contain calculational information on 1 -yr lung and marrow doses from inhalation, and preclean-up ground contamination levels for each isodose area. Page 17 lists the doses for incident-free transport. Page 18 is the incident-free importance analysis summary. Pages 19 and 20 are the accident risk summary.
\end{abstract}




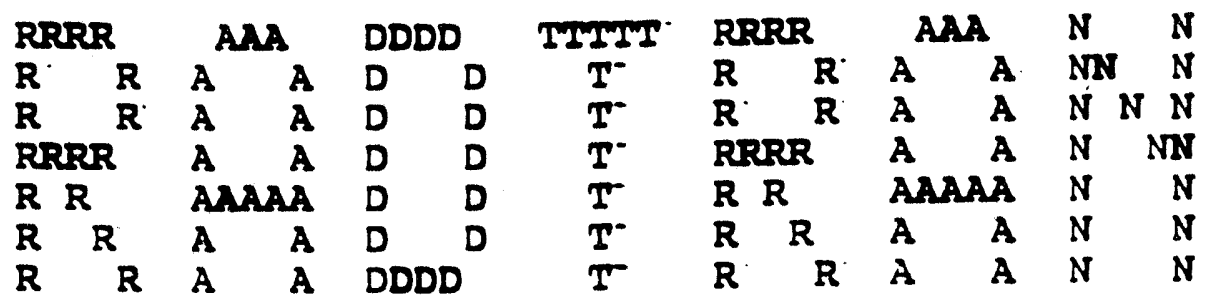

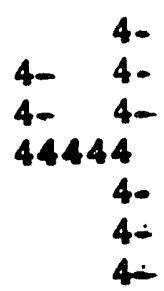

RADTRAN 4.0.13 VMRSION DATE: OCTOBER 27,1992

MODE DESCRIPTIONS

$\begin{array}{cl}\text { NUMIBER } & \text { NAME } \\ 1 . & \text { TRUCK } \\ 2- & \text { RAII } \\ 3 & \text { BARGE } \\ 4- & \text { SHIP } \\ 5 & \text { CARGO AIR } \\ 6 & \text { PASS AIR } \\ 7 & \text { P-VAN } \\ 8 & \text { CVAN-T } \\ 9 & \text { CVAN-R } \\ 10 & \text { CVAN-CA }\end{array}$

CEARACTERIZATION

LONG HAUL VEHICLE

COMLYERCIAI TRAIN

INIAND VESSEL

OPEN SEA VESSEL

CARGO AIRCRAFT

PASSENGER AIRCRAFT

PASSENGER VAN

COMMERCIAL VAN

COMMERCIAL VAN

COMMERCIAL VAN 


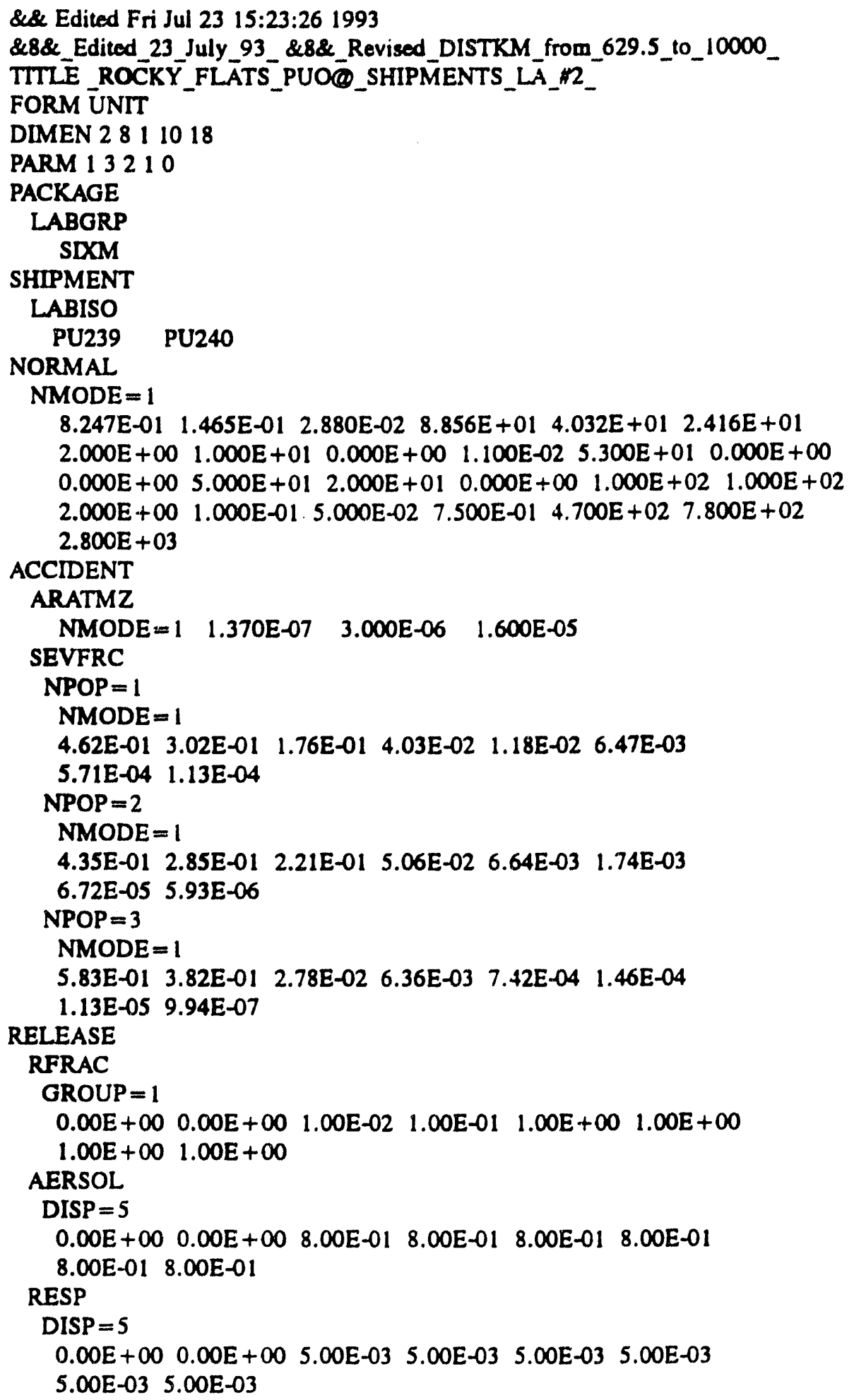




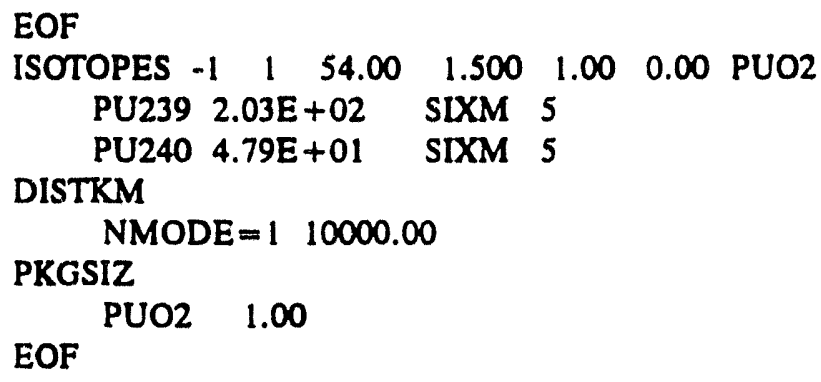

RURAL SUBURBAN URBAN

719.

PACKAGE CHARACTERISTICS

$\begin{array}{cccc}\begin{array}{c}\text { FOR } \\ \text { MATERIAL }\end{array} & \begin{array}{c}\text { DIMENSION } \\ \text { (METERS) }\end{array} & \begin{array}{c}\text { EFFECTIVE } \\ \text { DIMENSION }\end{array} & \begin{array}{c}K(0) \\ \text { METERS SQ. } \\ \text { PUO2 }\end{array} \\ 1.000 E+\infty 0 & 1.000 E+\infty 0 & 2.250 \mathrm{E}+00\end{array}$

$\mathrm{K}(0)$ IS TI TO DOSE RATE CONVERSION FACTOR

PACKAGE HANDLING THRESHOLDS (METERS)

PKGSZ1 $=5.000 \mathrm{E}-01$

PKGSZ2 $=1.000 E+00$

PACKAGES .LE. PKGSZ1 ARE HAND CARRIED

PACKAGES .GT. PKGSZ1 AND .LE. PKGSZ2 ARE HANDLED BY SMALL EQUIPMENT

PACKAGES .GT. PKGSZ2 ARE HANDLED BY HEAVY EQUIPMENT

\section{MATERIAL CHARACTERISTICS}

FRACTION FRACTION

MATERIAL OF GAMMA OF NEUTRON

PUO2 1.000E + $00 \quad 0.000 E+\infty$ 
MODE CHARACTERISTICS

MODE DISTANCE EXCLUSIVE NUMBER OF MATERIALS TRANSPORT PACKAGES/

TRAVELED USE SHIPMENTS INDEX (TI) SHIPMENT

TRUCK 1.00E +04 YES 1.00E +00

PUO2 1.50E +00 5.40E +01

BUILDING SHIELDING OPTION $=2$

( 1 = TOTAL SHIELDING, 2 = PARTIAL SHIELDING, 3 = NO SHIELDING)

$R P D=6.000 E+\infty$

(RATTO OF PEDESTRIAN DENSITY (PEDESTRIAN/KM SQ OF SIDEWALK)

TO POPULATION DENSITY (PEOPLE/KM SQ IN URBAN AREAS)

$R R=1.000 E+00$

(TRANSMISSION FACTOR FOR RURAL AREAS)

RS $=8.700 E-01$

(TRANSMISSION FACTOR FOR SUBURBAN AREAS)

$\mathrm{RU}=1.800 \mathrm{E}-02$

(TRANSMISSION FACTOR FOR URBAN AREAS)

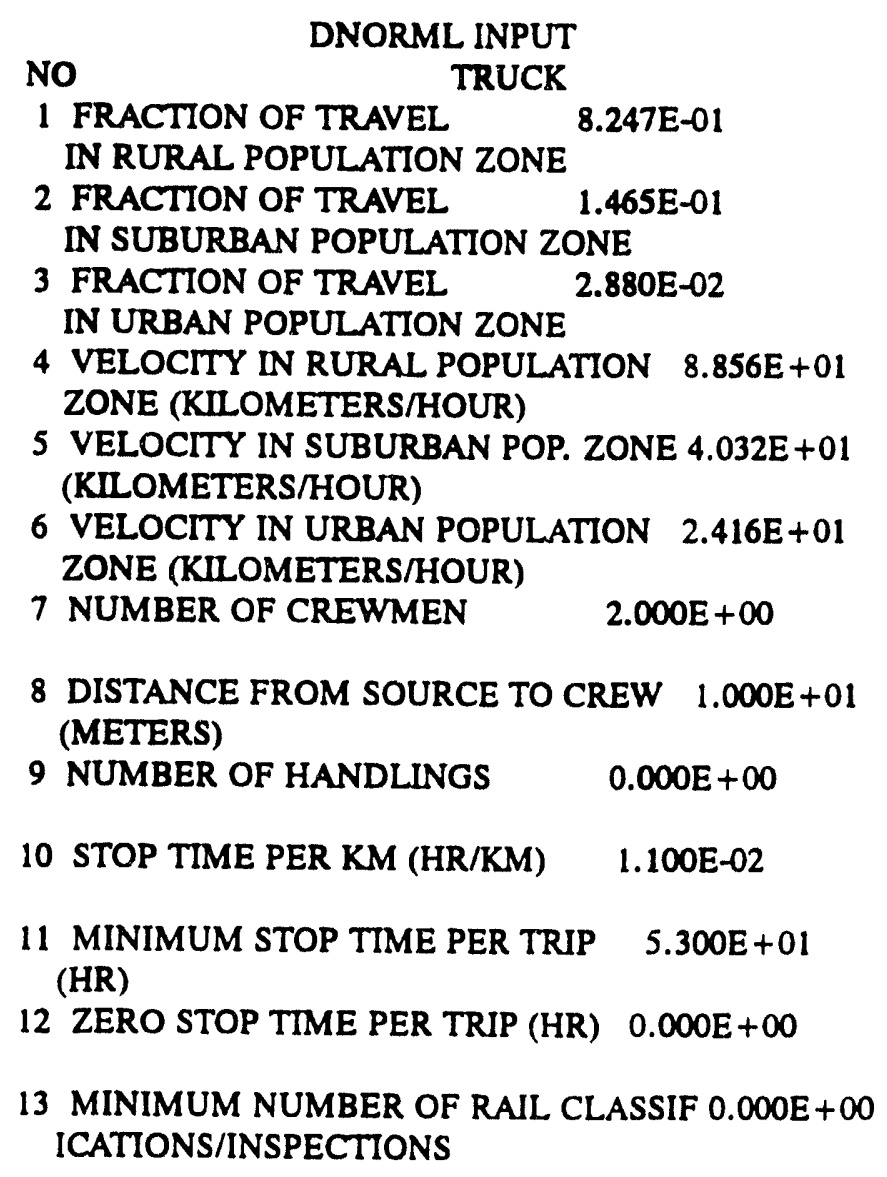


14 PERSONS EXPOSED WHILE STOPPED 5.000E +01

15 AVERAGE EXPOSURE DISTANCE 2.000E + 01 WHILE STOPPED (METERS)

16 STORAGE TIME PER SHIPMENT 0.000E + 00 (HR)

17 NUMBER OF EXPOSED PERSONS 1.000E + 02 DURING STORAGE

18 AVERAGE EXPOSURE DISTANCE $1.000 E+02$ WHILE IN STORAGE (METERS)

19 NUMBER OF PEOPLE PER VEHICLE 2.000E + 00 ON LINK

20 FRACTION OF URBAN TRAVEL 1.000E-01 DURING RUSH HOUR TRAFFIC

21 FRACTION OF URBAN TRAVEL 5.000E-02 ON CITY STREETS

22 FRACTION OF RURAL-SUBURBAN 7.500E-01 TRAVEL ON FREEWAYS

23 *TRAFFIC COUNT PASSING A 4.700E + 02 SPECIFIC POINT-RURAL ZONE

24 *TRAFFIC COUNT PASSING A 7.800E +02 SPECIFIC POINT-SUBURBAN ZONE

25 *TRAFFIC COUNT PASSING A 2.800E + 03 SPECIFIC POINT-URBAN ZONE *(ONE WAY VEHICLES/HR)

ISOTOPE RELATED DATA

NUCLIDE CURIES RELEASE RESUSP LUNG DISPERS. 1YR INHAL REM/CI PER PKG GROUP FACTOR TYPE CATEGORY LUNG MARROW

PUO2

$\begin{array}{lllllll}\text { PU239 2.03E }+02 \quad \text { SIXM } & 5.57 E+\infty & 3 & 5 & 4.20 E+08 & 1.10 E+06\end{array}$

PU240 4.79E +01 SIXM $5.56 E+10 \quad 3 \quad 5 \quad 4.20 E+081.10 E+06$

NUCLIDE HALF GAMMA CLOUD TRANSFER DEPOS

LIFE ENERGY FACTOR CROPS SOIL SPEED

PUO2

PU239 8.79E + 06 7.96E-04 $1.30 \mathrm{E}-05 \quad 0.00 \mathrm{E}+00 \quad 0.00 \mathrm{E}+00 \quad 1.00 \mathrm{E}-02$

PU240 2.39E + 06 1.73E-03 1.37E-05 $0.00 E+00 \quad 0.00 E+00 \quad 1.00 E-02$

NUCLIDE 50-YR EFFECTIVE REM/CI INHALE INGEST

PUO2

PU239 5.70E +08 4.30E +06

PU240 5.70E +08 4.30E +06 
ACCIDENT RATES (i . JR KM)

MODE RURAL SUBURBAN URBAN

TRUCK 1.370E-07 3.000E-06 1.600E-05

\section{RELEASE FRACTIONS}

GROUP SEVER: 1 SEVER: 2 SEVER: 3 SEVER: 4 SEVER: 5 SEVER: 6 SEVER: 7

$1 \quad 0.00 \mathrm{E}+00 \quad 0.00 \mathrm{E}+00 \quad 1.00 \mathrm{E}-02 \quad 1.00 \mathrm{E}-01 \quad 1.00 \mathrm{E}+00 \quad 1.00 \mathrm{E}+\infty 0^{0} \quad 1.00 \mathrm{E}+00$

GROUP SEVER: 8

$1 \quad 1.00 \mathrm{E}+\infty 0$

ACCIDENT SEVERITY FRACTIONS

FOR TRUCK

ZONE SEVER: 1 SEVER: 2 SEVER: 3 SEVER: 4 SEVER: 5 SEVER: 6 SEVER: 7

1 4.62E-01 3.02E-01 1.76E-01 4.03E-02 $1.18 \mathrm{E}-02 \quad 6.47 \mathrm{E}-03 \quad 5.71 \mathrm{E}-04$

$2 \quad 4.35 \mathrm{E}-01 \quad 2.85 \mathrm{E}-01 \quad 2.21 \mathrm{E}-01 \quad 5.06 \mathrm{E}-02 \quad 6.64 \mathrm{E}-03 \quad 1.74 \mathrm{E}-03 \quad 6.72 \mathrm{E}-05$

$3 \quad 5.83 E-01 \quad 3.82 E-01 \quad 2.78 E-02 \quad 6.36 E-03 \quad 7.42 E-04 \quad 1.46 E-04 \quad 1.13 E-05$

ZONE SEVER: 8

1 1.13E-04

$2 \quad 5.93 E-06$

$3 \quad 9.94 \mathrm{E}-07$

AEROSOLIZED FRACTION OF RELEASED MATERIAL

DISP CAT SEVER: 1 SEVER: 2 SEVER: 3 SEVER: 4 SEVER: 5 SEVER: 6 SEVER: 7

$1 \quad 0.00 \mathrm{E}+00 \quad 0.00 \mathrm{E}+00 \quad 0.00 \mathrm{E}+00 \quad 0.00 \mathrm{E}+00 \quad 0.00 \mathrm{E}+00 \quad 0.00 \mathrm{E}+00 \quad 0.00 \mathrm{E}+00$

$2 \quad 1.00 \mathrm{E}+\infty 0 \quad 1.00 \mathrm{E}+\infty \quad 1.00 \mathrm{E}+\infty \begin{array}{lllll}1.00 \mathrm{E}+\infty & 1.00 \mathrm{E}+00 & 1.00 \mathrm{E}+00 & 1.00 \mathrm{E}+00\end{array}$

$3 \quad 1.00 \mathrm{E}-02 \quad 1.00 \mathrm{E}-02 \quad 1.00 \mathrm{E}-02 \quad 1.00 \mathrm{E}-02 \quad 1.00 \mathrm{E}-02 \quad 1.00 \mathrm{E}-02 \quad 1.00 \mathrm{E}-02$

$4 \quad 5.00 \mathrm{E}-02 \quad 5.00 \mathrm{E}-02 \quad 5.00 \mathrm{E}-02 \quad 5.00 \mathrm{E}-02 \quad 5.00 \mathrm{E}-02 \quad 5.00 \mathrm{E}-02 \quad 5.00 \mathrm{E}-02$

$5 \quad 0.00 \mathrm{E}+00 \quad 0.00 \mathrm{E}+00 \quad 8.00 \mathrm{E}-01 \quad 8.00 \mathrm{E}-01 \quad 8.00 \mathrm{E}-01 \quad 8.00 \mathrm{E}-01 \quad 8.00 \mathrm{E}-01$

$\begin{array}{llllllll}6 & 1.00 \mathrm{E}+\infty & 1.00 \mathrm{E}+\infty & 1.00 \mathrm{E}+\infty & 1.00 \mathrm{E}+\infty & 1.00 \mathrm{E}+\infty & 1.00 \mathrm{E}+\infty & 1.00 \mathrm{E}+00\end{array}$

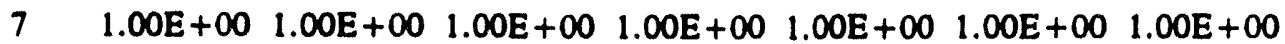

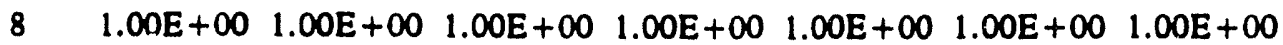

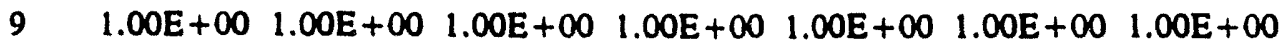

$\begin{array}{lllllllll}10 & 1.00 \mathrm{E}+\infty & 1.00 \mathrm{E}+\infty & 1.00 \mathrm{E}+\infty & 1.00 \mathrm{E}+\infty & 1.00 \mathrm{E}+\infty & 1.00 \mathrm{E}+\infty & 1.00 \mathrm{E}+\infty\end{array}$

$\begin{array}{lllllllllllll}11 & 1.00 \mathrm{E}+00 & 1.00 \mathrm{E}+00 & 1.00 \mathrm{E}+00 & 1.00 \mathrm{E}+00 & 1.00 \mathrm{E}+00 & 1.00 \mathrm{E}+00 & 1.00 \mathrm{E}+00\end{array}$ 


$\begin{array}{cc}\text { DISP CAT SEVER: } \\ 1 & 0.00 \mathrm{E}+\infty 0 \\ 2 & 1.00 \mathrm{E}+\infty 0 \\ 3 & 1.00 \mathrm{E}-02 \\ 4 & 5.00 \mathrm{E}-02 \\ 5 & 8.00 \mathrm{E}-01 \\ 6 & 1.00 \mathrm{E}+\infty \\ 7 & 1.00 \mathrm{E}+\infty \\ 8 & 1.00 \mathrm{E}+\infty \\ 9 & 1.00 \mathrm{E}+\infty \\ 10 & 1.00 \mathrm{E}+\infty 0 \\ 11 & 1.00 \mathrm{E}+\infty\end{array}$

FRACTION OF AEROSOLS BELOW 10 MICRONS AED

\begin{tabular}{|c|c|}
\hline \multicolumn{2}{|r|}{ DISP CAT SEVER: 1 SEVER: 2 SEVER: 3 SEVER: 4 SEVER: 5 SEVER: 6 SEVER: 7} \\
\hline 1 & 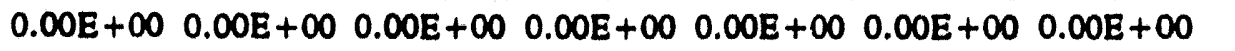 \\
\hline 2 & 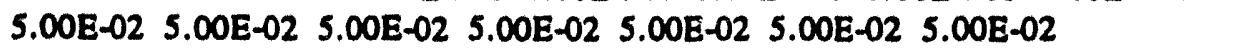 \\
\hline 3 & 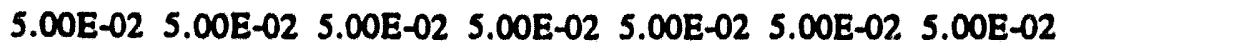 \\
\hline 4 & 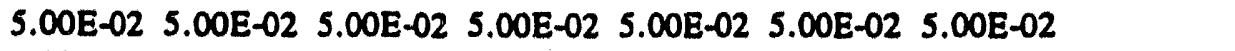 \\
\hline 5 & $0.00 \mathrm{E}+\infty 00.00 \mathrm{E}+\infty \quad 5.00 \mathrm{E}-03 \quad 5.00 \mathrm{E}-03 \quad 5.00 \mathrm{E}-03 \quad 5.00 \mathrm{E}-03 \quad 5.00 \mathrm{E}-03$ \\
\hline 6 & 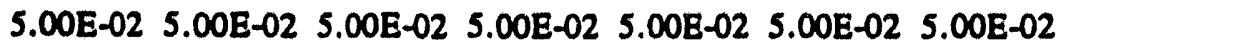 \\
\hline 7 & 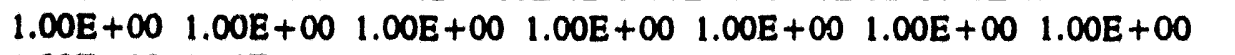 \\
\hline 8 & 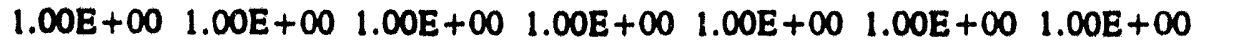 \\
\hline 9 & 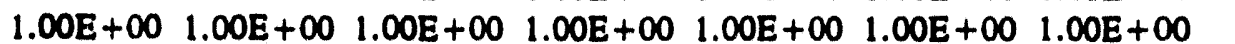 \\
\hline 10 & 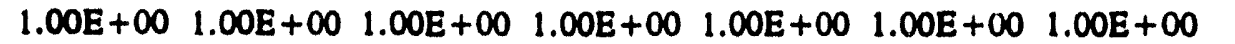 \\
\hline 11 & 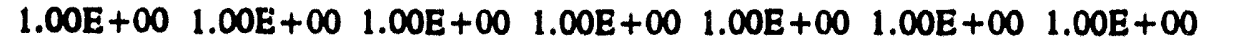 \\
\hline \multicolumn{2}{|c|}{ DISP CAT SEVER: 8} \\
\hline 1 & $0.00 \mathrm{E}+\infty$ \\
\hline 2 & 5.00E-02 \\
\hline 3 & $5.00 \mathrm{E}-02$ \\
\hline 4 & $5.00 \mathrm{E}-02$ \\
\hline 5 & $5.00 E-03$ \\
\hline 6 & $5.00 \mathrm{E}-02$ \\
\hline 7 & $1.00 \mathrm{E}+00$ \\
\hline 8 & $1.00 \mathrm{E}+\infty 0$ \\
\hline 9 & $1.00 \mathrm{E}+00$ \\
\hline 10 & $1.00 \mathrm{E}+\infty 0$ \\
\hline 11 & $1.00 \mathrm{E}+00$ \\
\hline
\end{tabular}




\title{
EMERGENCY RESPONSE COST
}

SEVER: 1 SEVER: 2 SEVER: 3 SEVER: 4 SEVER: 5 SEVER: 6 SEVER: 7

SEVER: 8

$1 \quad 0.00 E+\infty 0$

\author{
ON-SCENE COSTS \\ (RF = RELEASE FRACTION) \\ $R F=0 . \quad 0 .<R F<=.01 \quad .01<R F<=0.1 \quad .1<R F<=1$. \\ $0 . \quad 0 . \quad 0.0$.
}

HEALTH RELATED DATA

\section{EARLY FATALITY PROBABILITIES}

\begin{tabular}{|c|c|c|c|c|}
\hline DOSE(REN & LUNG- & LUNG-2 & LUNG-3 & MARROW \\
\hline 100000.000 & $1.000 \mathrm{E}+$ & $1.000 \mathrm{E}+$ & $1.000 \mathrm{E}+00$ & $1.000 E+00$ \\
\hline 80000.000 & $1.000 E+\infty 0$ & $8.500 E-01$ & $8.000 \mathrm{E}-01$ & $1.000 \mathrm{E}+00$ \\
\hline 70000.000 & $1.000 E+\infty 0$ & $8.000 \mathrm{E}-01$ & $5.000 \mathrm{E}-01$ & $1.000 E+\infty$ \\
\hline 40000.000 & $1.000 E+\infty$ & $7.000 E-01$ & $0.000 E+00$ & $1.000 E+00$ \\
\hline 30000.000 & $1.000 E+\infty$ & $5.000 \mathrm{E}-01$ & $0.000 E+00$ & $1.000 E+00$ \\
\hline 25000.000 & $1.000 E+\infty 0$ & $2.000 \mathrm{E}-01$ & $0.000 E+00$ & $1.000 E+\infty$ \\
\hline 20000.000 & $1.000 E+\infty$ & $8.000 E-02$ & $0.000 \mathrm{E}+00$ & $1.000 E+\infty 0$ \\
\hline 10000.000 & $6.000 E-01$ & $0.000 E+\infty 0$ & $0.000 E+\infty 0$ & $1.000 E+00$ \\
\hline 8000.000 & $1.000 \mathrm{E}-01$ & $0.000 \mathrm{E}+\infty 0$ & $0.000 E+00$ & $1.000 \mathrm{E}+00$ \\
\hline 6000.000 & $6.000 \mathrm{E}-02$ & $0.000 E+00$ & $0.000 E+\infty 0$ & $1.000 E+\infty 0$ \\
\hline 4000.000 & $3.000 \mathrm{E}-02$ & $0.000 \mathrm{E}+\infty 0$ & $0.000 \mathrm{E}+00$ & $1.000 \mathrm{E}+00$ \\
\hline 3000.000 & $0.000 \mathrm{E}+00$ & $0.000 \mathrm{E}+00$ & $0.000 E+\infty 0$ & $1.000 \mathrm{E}+00$ \\
\hline 2000.000 & $0.000 \mathrm{E}+00$ & $0.000 E+\infty 0$ & $0.000 \mathrm{E}+00$ & $1.000 E+00$ \\
\hline 1000.000 & $0.000 \mathrm{E}+\infty 0$ & $0.000 E+\infty 0$ & $0.000 E+00$ & $1.000 E+\infty 0$ \\
\hline 800.000 & $0.000 E+\infty 0$ & $0.000 E+00$ & $0.000 E+\infty 0$ & $9.960 \mathrm{E}-01$ \\
\hline 700.000 & $0.000 E+\infty$ & $0.000 E+\infty 0$ & $0.000 E+00$ & $9.000 \mathrm{E}-01$ \\
\hline 600.000 & $0.000 E+\infty 0$ & $0.000 E+00$ & $0.000 E+00$ & $4.000 \mathrm{E}-01$ \\
\hline 500.000 & $0.000 \mathrm{E}+\infty 0$ & $0.000 E+\infty 0$ & $0.000 E+00$ & $5.000 E-02$ \\
\hline 400 & 0.00 & .00 & $0.000 \mathrm{E}$ & 0.00 \\
\hline 300.000 & $0.000 E+\infty 0$ & $0.000 E+\infty 0$ & $0.000 \mathrm{E}+\infty 0$ & $0.000 \mathrm{E}+00$ \\
\hline 100.000 & $0.000 \mathrm{E}+00$ & $0.000 \mathrm{E}+\infty 0$ & $0.000 \mathrm{E}+\infty 0$ & $0.000 E+00$ \\
\hline 75.000 & $0.000 E+00$ & $0.000 \mathrm{E}+\infty$ & $0.000 E+00$ & $0.000 E+\infty 0$ \\
\hline 50.000 & $0.000 E+00$ & $0.000 E+00$ & $0.000 E+00$ & $0.000 E+\infty 0$ \\
\hline 30.000 & $0.000 \mathrm{E}+00$ & $0.000 \mathrm{E}+00$ & $0.000 E+00$ & $0.000 E+\infty 0$ \\
\hline 15.000 & $0.000 E+00$ & $0.000 E+00$ & $0.000 \mathrm{E}+00$ & $0.000 \mathrm{E}+00$ \\
\hline 5.000 & $0.000 E+\infty 0$ & $0.000 \mathrm{E}+00$ & $0.000 E+00$ & $0.000 E+00$ \\
\hline 1.000 & $0.000 E+00$ & $0.000 \mathrm{E}+00$ & $0.000 \mathrm{E}+00$ & $0.000 E+00$ \\
\hline 0.100 & 00 & & $0.000 E+00$ & $0.000 E+00$ \\
\hline 0.010 & $0.000 E+00$ & $0.000 \mathrm{E}+00$ & $0.000 \mathrm{E}+\infty 0$ & $0.000 E+\infty 0$ \\
\hline 0.010 & $0.000 E+\infty 0$ & $0.000 \mathrm{E}+00$ & $0.000 E+00$ & $0.000 \mathrm{E}+\infty 0$ \\
\hline
\end{tabular}


DISPERSAL ACCIDENT INPUT

$\begin{array}{cc}\begin{array}{c}\text { AREADA } \\ (M \text { SQ) }\end{array} & \begin{array}{c}\text { DILUTION } \\ \text { FACTOR* }\end{array} \\ \begin{array}{c}4.590 \mathrm{E}+02 \\ 1.530 \mathrm{E}+03\end{array} & 3.420 \mathrm{E}-03 \\ 3.940 \mathrm{E}+03 & 8.720 \mathrm{E}-03 \\ 1.250 \mathrm{E}+04 & 3.420 \mathrm{E}-04 \\ 3.040 \mathrm{E}+04 & 1.720 \mathrm{E}-04 \\ 6.850 \mathrm{E}+04 & 8.580 \mathrm{E}-05 \\ 1.760 \mathrm{E}+05 & 3.420 \mathrm{E}-05 \\ 4.450 \mathrm{E}+05 & 1.720 \mathrm{E}-05 \\ 8.590 \mathrm{E}+05 & 3.580 \mathrm{E}-06 \\ 2.550 \mathrm{E}+06 & 3.420 \mathrm{E}-06 \\ 4.450 \mathrm{E}+06 & 1.720 \mathrm{E}-06 \\ 1.030 \mathrm{E}+07 & 8.580 \mathrm{E}-07 \\ 2.160 \mathrm{E}+07 & 3.420 \mathrm{E}-07 \\ 5.520 \mathrm{E}+07 & 1.720 \mathrm{E}-07 \\ 1.770 \mathrm{E}+08 & 8.580 \mathrm{E}-08 \\ 4.890 \mathrm{E}+08 & 5.420 \mathrm{E}-08 \\ 8.120 \mathrm{E}+08 & 4.300 \mathrm{E}-08 \\ 1.350 \mathrm{E}+09 & 3.420 \mathrm{E}-08\end{array}$

* DILUTION FACTOR UNITS ARE (CI-SEC/M**3/CI-RELEASED)

NON-DISPERSAL ACCIDENT INPUT

\title{
RADIST(M)
}

RURAL SUBURBAN URBAN

3.050E + $00 \quad 3.050 E+\infty 0 \quad 3.050 E+00$

$6.100 E+\infty 0 \quad 6.100 E+\infty \quad 6.100 E+\infty 0$

$9.100 \mathrm{E}+\infty 0 \quad 9.100 \mathrm{E}+\infty 0 \quad 9.100 \mathrm{E}+\infty 0$

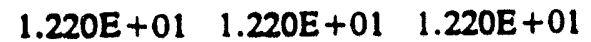

$1.520 \mathrm{E}+01 \quad 1.520 \mathrm{E}+01 \quad 1.520 \mathrm{E}+01$

3.050E +01 3.050E +01 3.050E+01

6.100E+01 $6.100 \mathrm{E}+01 \quad 6.100 \mathrm{E}+01$

$9.140 E+01 \quad 9.140 E+01 \quad 9.140 E+01$

$1.524 \mathrm{E}+02 \quad 1.524 \mathrm{E}+02 \quad 1.524 \mathrm{E}+02$
$3.050 \mathrm{E}+02$

$3.050 \mathrm{E}+02 \quad 3.050 \mathrm{E}+02 \quad 3.050 \mathrm{E}+02$

\begin{abstract}
BUILDING DOSE FACTOR $\quad=8.600 \mathrm{E}-03$
FRACTION OF LAND UNDER CULTIVATION $=5.000 \mathrm{E}-01$

CONTAMINATION CLEAN UP LEVEL (UCI/M**2) $=2.000 \mathrm{E}-01$

BREATHING RATE $\left(\mathrm{M}^{* * 3 / \mathrm{SEC})} \quad=3.300 \mathrm{E}-04\right.$
\end{abstract}


FOR THE SHIPMENT OF PUO2 BY MODE 1

THE SURFACE DOSE RATE COULD EXCEED 200 MREM/HR

PPS TI HAS BEEN RESET TO EQUAL 66.67

FOR THE SHIPMENT OF PUO2 BY MODE 1

THE DOSE RATE AT 2 METERS COULD EXCEED $10 \mathrm{MR} / \mathrm{HR}$

PPS TI HAS BEEN RESET TO EQUAL 16.67

CALCULATIONAL INFORMATION FOR MODE TRUCK

FOR SEVERITY CATEGORY 3 AREA 1 HAS BEEN INTERDICTED.

THERE WILL BE NO 50 YEAR GROUNDSHINE DOSE AND NO INGESTION DOSE.

FOR SEVERTTY CATEGORY 3 AREA 2 HAS BEEN INTERDICTED.

THERE WILL BE NO 50 YEAR GROUNDSHINE DOSE AND NO INGESTION DOSE.

FOR SEVERITY CATEGORY 3 AREA 3 HAS BEEN INTERDICTED.

THERE WILL BE NO 50 YEAR GROUNDSHINE DOSE AND NO INGESTION DOSE.

FOR SEVERTTY CATEGORY 3 AREA 4 HAS BEEN INTERDICTED.

THERE WILL BE NO 50 YEAR GROUNDSHINE DOSE AND NO INGESTION DOSE.

FOR SEVERITY CATEGORY 3 AREA 5 HAS BEEN INTERDICTED.

THERE WILL BE NO 50 YEAR GROUNDSHINE DOSE AND NO INGESTION DOSE.

FOR SEVERITY CATEGORY 3 AREA 6 HAS BEEN INTERDICTED.

THERE WILL BE NO 50 YEAR GROUNDSHINE DOSE AND NO INGESTION DOSE.

FOR SEVERITY CATEGORY 3 AREA 7 HAS BEEN INTERDICTED.

THERE WILL BE NO 50 YEAR GROUNDSHINE DOSE AND NO INGESTION DOSE.

FOR SEVERITY CATEGORY 3 AREA 8 HAS BEEN INTERDICTED.

THERE WILL BE NO 50 YEAR GROUNDSHINE DOSE AND NO INGESTION DOSE.

FOR SEVERITY CATEGORY 4 AREA 1 HAS BEEN INTERDICTED.

THERE WILL BE NO 50 YEAR GROUNDSHINE DOSE AND NO INGESTION DOSE.

FOR SEVERITY CATEGORY 4 AREA 2 HAS BEEN INTERDICTED.

THERE WILL BE NO 50 YEAR GROUNDSHINE DOSE AND NO INGESTION DOSE.

FOR SEVERITY CATEGORY 4 AREA 3 HAS BEEN INTERDICTED.

THERE WILL BE NO 50 YEAR GROUNDSHINE DOSE AND NO INGESTION DOSE.

FOR SEVERITY CATEGORY 4 AREA 4 HAS BEEN INTERDICTED.

THERE WILL BE NO 50 YEAR GROUNDSHINE DOSE AND NO INGESTION DOSE.

FOR SEVERITY CATEGORY 4 AREA 5 HAS BEEN INTERDICTED.

THERE WILL BE NO 50 YEAR GROUNDSHINE DOSE AND NO INGESTION DOSE. 
FOR SEVERITY CATEGORY 4 AREA 6 HAS BEEN INTERDICTED.

THERE WILL BE NO 50 YEAR GROUNDSHINE DOSE AND NO INGESTION DOSE.

FOR SEVERITY CATEGORY 4 AREA 7 HAS BEEN INTERDICTED.

THERE WILL BE NO $5 O$ YEAR GROUNDSHINE DOSE AND NO INGESTION DOSE.

FOR SEVERTTY CATEGORY 4 AREA 8 HAS BEEN INTERDICTED.

THERE WILL BE NO 50 YEAR GROUNDSHINE DOSE AND NO INGESTION DOSE.

FOR SEVERTTY CATEGORY 4 AREA 9 HAS BEEN INTERDICTED.

THERE WILL BE NO 50 YEAR GROUNDSHINE DOSE AND NO INGESTION DOSE.

FOR SEVERITY CATEGORY 4 AREA 10 HAS BEEN INTERDICTED.

THERE WILL BE NO 50 YEAR GROUNDSHINE DOSE AND NO INGESTION DOSE.

FOR SEVERTTY CATEGORY 4 AREA 11 HAS BEEN INTERDICTED.

THERE WILL BE NO 50 YEAR GROUNDSHINE DOSE AND NO INGESTION DOSE.

FOR SEVERITY CATEGORY 5 AREA 1 HAS BEEN INTERDICTED.

THERE WILL BE NO $5 O$ YEAR GROUNDSHINE DOSE AND NO INGESTION DOSE.

FOR SEVERITY CATEGORY 5 AREA 2 HAS BEEN INTERDICTED.

THERE WILI BE NO 50 YEAR GROUNDSHINE DOSE AND NO INGESTION DOSE.

FOR SEVERITY CATEGORY 5 AREA 3 HAS BEEN INTERDICTED.

THERE WILL BE NO 50 YEAR GROUNDSHINE DOSE AND NO INGESTION DOSE.

FOR SEVERITY CATEGORY 5 AREA 4 HAS BEEN !

THERE WILL BE NO 50 YEAR GROUNDSHINE DOS

TTED.

O INGESTION DOSE.

FOR SEVERITY CATEGORY 5 AREA 5 HAS BEEN INTERDICTED.

THERE WILL BE NO 50 YEAR GROUNDSHINE DOSE AND NO INGESTION DOSE.

FOR SEVERITY CATEGORY 5 AREA 6 HAS BEEN INTERDICTED.

THERE WTLL BE NO SO YEAR GROUNDSHINE DOSE AND NO INGESTION DOSE.

FOR SEVERITY CATEGORY 5 AREA 7 HAS BEEN INTERDICTED.

THERE WILL BE NO 50 YEAR GROUNDSHINE DOSE AND NO INGESTION DOSE.

FOR SEVERITY CATEGORY 5 AREA 8 HAS BEEN INTERDICTED.

THERE WILL BE NO 50 YEAR GROUNDSHINE DOSE AND NO INGESTION DOSE.

FOR SEVERTTY CATEGORY 5 AREA 9 HAS BEEN INTERDICTED.

THERE WILL BE NO 50 YEAR GROUNDSHINE DOSE AND NO INGESTION DOSE.

FOR SEVERITY CATEGORY S AREA 10 HAS BEEN INTERDICTED.

THERE WILL BE NO $5 O$ YEAR GROUNDSHINE DOSE AND NO INGESTION DOSE.

FOR SEVERITY CATEGORY 5 AREA 11 HAS BEEN INTERDICTED.

THERE WILL BE NO 50 YEAR GROUNDSHINE DOSE AND NO INGESTION DUSE.

SOR SEVERITY CATEGORY 5 AREA 12 HAS BEEN! INTERDICTED.

THERE WILL BE NO 50 YEAR GROUNDSHINE DOSE AND NO INGESTION DOSE. 
FOR SEVERITY CATEGORY 5 AREA 13 HAS BEEN INTERDICTED.

THERE WILL BE NO 50 YEAR GROUNDSHINE DOSE AND NO INGESTION DOSE.

FOR SEVERITY CATEGORY 5 AREA 14 HAS BEEN INTERDICTED.

THERE WILL BE NO 50 YEAR GROUNDSHINE DOSE AND NO INGESTION DOSE.

FOR SEVERTY CATEGORY 6 AREA 1 HAS BEEN INTERDICTED.

THERE WILL BE NO 50 YEAR GROUNDSHINE DOSE AND NO INGESTION DOSE.

FOR SEVERITY CATEGORY 6 AREA 2 HAS BEEN INTERDICTED.

THERE WILL BE NO 50 YEAR GROUNDSHINE DOSE AND NO INGESTION DOSE.

FOR SEVERITY CATEGORY 6 AREA 3 HAS BEEN INTERDICTED.

THERE WILL BE NO 50 YEAR GROUNDSHINE DOSE AND NO INGESTION DOSE.

FOR SEVERITY CATEGORY 6 AREA 4 HAS BEEN INTERDICTED.

THERE WILL BE NO 50 YEAR GROUNDSHINE DOSE AND NO INGESTION DOSE.

FOR SEVERITY CATEGORY 6 AREA 5 HAS BEEN INTERDICTED.

THERE WILL BE NO 50 YEAR GROUNDSHINE DOSE AND NO INGESTION DOSE.

FOR SEVERITY CATEGORY 6 AREA 6 HAS BEEN INTERDICTED.

THERE WILL BE NO 50 YEAR GROUNDSHINE DOSE AND NO INGESTION DOSE.

FOR SEVERITY CATEGORY 6 AREA 7 HAS BEEN INTERDICTED.

THERE WILL BE NO 50 YEAR GROUNDSHINE DOSE AND NO INGESTION DOSE.

FOR SEVERITY CATEGORY 6 AREA 8 HAS BEEN INTERDICTED.

THERE WILL BE NO 50 YEAR GROUNDSHINE DOSE AND NO INGESTION DOSE.

FOR SEVERITY CATEGORY 6 AREA 9 HAS BEEN INTERDICTED.

THERE WILL BE NO 50 YEAR GROUNDSHINE DOSE AND NO INGESTION DOSE.

FOR SEVERITY CATEGORY 6 AREA 10 HAS BEEN INTERDICTED.

THERE WILL BE NO 50 YEAR GROUNDSHINE DOSE AND NO INGESTION DOSE.

FOR SEVERTY CATEGORY 6 AREA 11 HAS BEEN INTERDICTED.

THERE WILL BE NO 50 YEAR GROUNDSHINE DOSE AND NO INGESTION DOSE.

FOR SEVERITY CATEGORY 6 AREA 12 HAS BEEN INTERDICTED.

THERE WILL BE NO 50 YEAR GROUNDSHINE DOSE AND NO INGESTION DOSE.

FOR SEVERITY CATEGORY 6 AREA 13 HAS BEEN INTERDICTED.

THERE WILL BE NO 50 YEAR GROUNDSHINE DOSE AND NO INGESTION DOSE.

FOR SEVERITY CATEGORY 6 AREA 14 HAS BEEN INTERDICTED.

THERE WILL BE NO 50 YEAR GROUNDSHINE DOSE AND NO INGESTION DOSE.

FOR SEVERITY CATEGORY 7 AREA I HAS BEEN INTERDICTED.

THERE WILL BE NO 50 YEAR GROUNDSHINE DOSE AND NO INGESTION DOSE.

FOR SEVERTTY CATEGORY 7 AREA 2 HAS BEEN INTERDICTED.

THERE WILL BE NO 50 YEAR GROUNDSHINE DOSE AND NO INGESTION DOSE.

FOR SEVERITY CATEGORY 7 AREA 3 HAS BEEN INTERDICTED. 
THERE WILL BE NO 50 YEAR GROUNDSHINE DOSE AND NO INGESTION DOSE.

FOR SEVERTTY CATEGORY 7 AREA 4 HAS BEEN INTERDICTED.

THERE WILL BE NO 50 YEAR GROUNDSHINE DOSE AND NO INGESTION DOSE.

FOR SEVERITY CATEGORY 7 AREA 5 HAS BEEN INTERDICTED.

THERE WILL BE NO 50 YEAR GROUNDSHINE DOSE AND NO INGESTION DOSE.

FOR SEVERTTY CATEGORY 7 AREA 6 HAS BEEN INTERDICTED.

THERE WILL BE NO 50 YEAR GROUNDSHINE DOSE AND NO INGESTION DOSE.

FOR SEVERITY CATEGORY 7 AREA 7 HAS BEEN INTERDICTED.

THERE WILL BE NO 50 YEAR GROUNDSHINE DOSE AND NO INGESTION DOSE.

FOR SEVERITY CATEGORY 7 AREA 8 HAS BEEN INTERDICTED.

THERE WILL BE NO 50 YEAR GROUNDSHINE DOSE AND NO INGESTION DOSE.

FOR SEVERITY CATEGORY 7 AREA 9 HAS BEEN INTERDICTED.

THERE WILL BE NO 50 YEAR GROUNDSHINE DOSE AND NO INGESTION DOSE.

FOR SEVERITY CATEGORY 7 AREA 10 HAS BEEN INTERDICTED.

THERE WILL BE NO 50 YEAR GROUNDSHINE DOSE AND NO INGESTION DOSE.

FOR SEVERTTY CATEGORY 7 AREA 11 HAS BEEN INTERDICTED.

THERE WILL BE NO 50 YEAR GROUNDSHINE DOSE AND NO INGESTION DOSE.

FOR SEVERITY CATEGORY 7 AREA 12 HAS BEEN INTERDICTED.

THERE WILL BE NO 50 YEAR GROUNDSHINE DOSE AND NO INGESTION DOSE.

FOR SEVERITY CATEGORY 7 AREA 13 HAS BEEN INTERDICTED.

THERE WILL BE NO 50 YEAR GROUNDSHINE DOSE AND NO INGESTION DOSE.

FOR SEVERTTY CATEGORY 7 AREA 14 HAS BEEN INTERDICTED.

THERE WILL BE NO 50 YEAR GROUNDSHINE DOSE AND NO INGESTION DOSE.

FOR SEVERITY CATEGORY 8 AREA 1 HAS BEEN INTERDICTED.

THERE WILL BE NO 50 YEAR GROUNDSHINE DOSE AND NO INGESTION DOSE.

FOR SEVERITY CATEGORY 8 AREA 2 HAS BEEN INTERDICTED.

THERE WILL BE NO 50 YEAR GROUNDSHINE DOSE AND NO INGESTION DOSE.

FOR SEVERITY CATEGORY 8 AREA 3 HAS BEEN INTERDICTED.

THERE WILL BE NO 50 YEAR GROUNDSHINE DOSE AND NO INGESTION DOSE.

FOR SEVERITY CATEGORY 8 AREA 4 HAS BEEN INTERDICTED.

THERE WILL BE NO 50 YEAR GROUNDSHINE DOSE AND NO INGESTION DOSE.

FOR SEVERITY CATEGORY 8 AREA 5 HAS BEEN INTERDICTED.

THERE WILL BE NO 50 YEAR GROUNDSHINE DOSE AND NO INGESTION DOSE.

FOR SEVERITY CATEGORY 8 AREA 6 HAS BEEN INTERDICTED.

THERE WILL BE NO 50 YEAR GROUNDSHINE DOSE AND NO INGESTION DOSE.

FOR SEVERITY CATEGORY 8 AREA 7 HAS BEEN INTERDICTED.

THERE WILL BE NO 50 YEAR GROUNDSHINE DOSE AND NO INGESTION DOSE. 
FOR SEVERTTY CATEGORY 8 AREA 8 HAS BEEN INTERDICTED. THERE WILL BE NO 50 YEAR GROUNDSHINE DOSE AND NO INGESTION DOSE.

FOR SEVERITY CATEGORY 8 AREA 9 HAS BEEN INTERDICTED. THERE WILL BE NO 50 YEAR GROUNDSHINE DOSE AND NO INGESTION DOSE.

FOR SEVERITY CATEGORY 8 AREA 10 HAS BEEN INTERDICTED. THERE WILL BE NO 50 YEAR GROUNDSHINE DOSE AND NO INGESTION DOSE.

FOR SEVERITY CATEGORY 8 AREA 11 HAS BEEN INTERDICTED.

THERE WILL BE NO 50 YEAR GROUNDSHINE DOSE AND NO INGESTION DOSE.

FOR SEVERITY CATEGORY 8 AREA 12 HAS BEEN INTERDICTED. THERE WILL BE NO 50 YEAR GROUNDSHINE DOSE AND NO INGESTION DOSE.

FOR SEVERITY CATEGORY 8 AREA 13 HAS BEEN INTERDICTED.

THERE WTLL BE NO 50 YEAR GROUNDSHINE DOSE AND NO INGESTION DOSE.

FOR SEVERTYY CATEGORY 8 AREA 14 HAS BEEN INTERDICTED.

THERE WTLL BE NO 50 YEAR GROUNDSHINE DOSE AND NO INGESTION DOSE.

MODE TRUCK

1-YEAR LUNG DOSE - INHALATION PATHWAY

$B D F=1 \quad(R E M)$

\footnotetext{
AREA \# SEVER: 1 SEVER: 2 SEVER: 3 SEVER: 4 SEVER: 5 SEVER: 6 SEVER: 7

$1 \quad 0.00 \mathrm{E}+00 \quad 0.00 \mathrm{E}+00 \quad 2.57 \mathrm{E}+02 \quad 2.57 \mathrm{E}+03 \quad 2.57 \mathrm{E}+04 \quad 2.57 \mathrm{E}+04 \quad 2.57 \mathrm{E}+04$

$\begin{array}{lllllll}0.00 \mathrm{E}+00 & 0.00 \mathrm{E}+00 & 1.29 \mathrm{E}+02 & 1.29 \mathrm{E}+03 & 1.29 \mathrm{E}+04 & 1.29 \mathrm{E}+04 & 1.29 \mathrm{E}+04\end{array}$

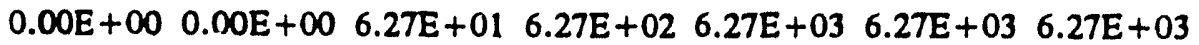

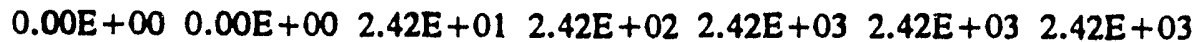

$0.00 \mathrm{E}+00 \quad 0.00 \mathrm{E}+00 \quad 1.16 \mathrm{E}+01 \quad 1.16 \mathrm{E}+02 \quad 1.16 \mathrm{E}+03 \quad 1.16 \mathrm{E}+03 \quad 1.16 \mathrm{E}+03$

$0.00 \mathrm{E}+\infty 00.00 \mathrm{E}+00 \quad 5.54 \mathrm{E}+00 \quad 5.54 \mathrm{E}+01 \quad 5.54 \mathrm{E}+02 \quad 5.54 \mathrm{E}+02 \quad 5.54 \mathrm{E}+02$

$0.00 \mathrm{E}+00 \quad 0.00 \mathrm{E}+00 \quad 2.10 \mathrm{E}+00 \quad 2.10 \mathrm{E}+01 \quad 2.10 \mathrm{E}+02 \quad 2.10 \mathrm{E}+02 \quad 2.10 \mathrm{E}+02$

$0.00 \mathrm{E}+\infty 0.00 \mathrm{E}+\infty 00$ 9.95E-01 9.95E +00 9.95E +01 9.95E+01 9.95E +01

$0.00 \mathrm{E}+00 \quad 0.00 \mathrm{E}+\infty \quad 4.63 \mathrm{E}-01 \quad 4.63 \mathrm{E}+00 \quad 4.63 \mathrm{E}+01 \quad 4.63 \mathrm{E}+01 \quad 4.63 \mathrm{E}+01$

$0.00 \mathrm{E}+00 \quad 0.00 \mathrm{E}+00 \quad 1.75 \mathrm{E}-01 \quad 1.75 \mathrm{E}+00 \quad 1.75 \mathrm{E}+01 \quad 1.75 \mathrm{E}+01 \quad 1.75 \mathrm{E}+01$

$0.00 \mathrm{E}+\infty 0000 \mathrm{E}+\infty 007.97 \mathrm{E}-02 \quad 7.97 \mathrm{E}-01 \quad 7.97 \mathrm{E}+\infty \quad 7.97 \mathrm{E}+\infty 0$ 7.97E $+\infty 0$

$0.00 \mathrm{E}+\infty 0 \quad 0.00 \mathrm{E}+\infty \quad 3.78 \mathrm{E}-02 \quad 3.78 \mathrm{E}-01 \quad 3.78 \mathrm{E}+\infty \quad 3.78 \mathrm{E}+\infty 0 \quad 3.78 \mathrm{E}+\infty 0$

$\begin{array}{lllllll}0.00 \mathrm{E}+\infty & 0.00 \mathrm{E}+\infty & 1.40 \mathrm{E}-02 & 1.40 \mathrm{E}-01 & 1.40 \mathrm{E}+\infty & 1.40 \mathrm{E}+00 & 1.40 \mathrm{E}+\infty\end{array}$

$0.00 \mathrm{E}+\infty 0.00 \mathrm{E}+00 \quad 6.59 \mathrm{E}-03 \quad 6.59 \mathrm{E}-02 \quad 6.59 \mathrm{E}-01 \quad 6.59 \mathrm{E}-01 \quad 6.59 \mathrm{E}-01$

$0.00 \mathrm{E}+00 \quad 0.00 \mathrm{E}+\infty \quad 3.01 \mathrm{E}-03 \quad 3.01 \mathrm{E}-02 \quad 3.01 \mathrm{E}-01 \quad 3.01 \mathrm{E}-01 \quad 3.01 \mathrm{E}-01$

$\begin{array}{lllllll}0.00 \mathrm{E}+\infty & 0.00 \mathrm{E}+\infty & 1.61 \mathrm{E}-03 & 1.61 \mathrm{E}-02 & 1.61 \mathrm{E}-01 & 1.61 \mathrm{E}-01 & 1.61 \mathrm{E}-01\end{array}$

$0.00 \mathrm{E}+00 \quad 0.00 \mathrm{E}+00 \quad 9.81 \mathrm{E}-04 \quad 9.81 \mathrm{E}-03 \quad 9.81 \mathrm{E}-02 \quad 9.81 \mathrm{E}-02 \quad 9.81 \mathrm{E}-02$

$0.00 \mathrm{E}+\infty \quad 0.00 \mathrm{E}+00 \quad 6.41 \mathrm{E}-04 \quad 6.41 \mathrm{E}-03 \quad 6.41 \mathrm{E}-02 \quad 6.41 \mathrm{E}-02 \quad 6.41 \mathrm{E}-02$
} 


$\begin{array}{cl}\text { AREA \# } & \text { SEVER: } 8 \\ 1 & 2.57 \mathrm{E}+04 \\ 2 & 1.29 \mathrm{E}+04 \\ 3 & 6.27 \mathrm{E}+03 \\ 4 & 2.42 \mathrm{E}+03 \\ 5 & 1.16 \mathrm{E}+03 \\ 6 & 5.54 \mathrm{E}+02 \\ 7 & 2.10 \mathrm{E}+02 \\ 8 & 9.95 \mathrm{E}+01 \\ 9 & 4.63 \mathrm{E}+01 \\ 10 & 1.75 \mathrm{E}+01 \\ 11 & 7.97 \mathrm{E}+00 \\ 12 & 3.78 \mathrm{E}+00 \\ 13 & 1.40 \mathrm{E}+00 \\ 14 & 6.59 \mathrm{E}-01 \\ 15 & 3.01 \mathrm{E}-01 \\ 16 & 1.61 \mathrm{E}-01 \\ 17 & 9.81 \mathrm{E}-02 \\ 18 & 6.41 \mathrm{E}-02 .\end{array}$

1-YEAR MARROW DOSE - INHALATION PATHWAY $B D F=1 \quad(R E M)$

\footnotetext{
AREA \# SEVER: 1 SEVER: 2 SEVER: 3 SEVER: 4 SEVER: 5 SEVER: 6 SEVER: 7 $1 \quad 0.00 E+00 \quad 0.00 E+00 \quad 6.73 E-01 \quad 6.73 E+00 \quad 6.73 E+01 \quad 6.73 E+01 \quad 6.73 E+01$

$2 \quad 0.00 \mathrm{E}+\infty 0.00 \mathrm{E}+\infty \quad 3.38 \mathrm{E}-01 \quad 3.38 \mathrm{E}+00 \quad 3.38 \mathrm{E}+01 \quad 3.38 \mathrm{E}+01 \quad 3.38 \mathrm{E}+01$

$\begin{array}{lllllllll}3 & 0.00 \mathrm{E}+00 & 0.00 \mathrm{E}+00 & 1.64 \mathrm{E}-01 & 1.64 \mathrm{E}+00 & 1.64 \mathrm{E}+01 & 1.64 \mathrm{E}+01 & 1.64 \mathrm{E}+01\end{array}$

$\begin{array}{llllllll}4 & 0.00 \mathrm{E}+\infty & 0.00 \mathrm{E}+\infty & 6.35 \mathrm{E}-02 & 6.35 \mathrm{E}-01 & 6.35 \mathrm{E}+\infty & 6.35 \mathrm{E}+\infty & 6.35 \mathrm{E}+\infty\end{array}$

$\begin{array}{llllllllll}5 & 0.00 \mathrm{E}+00 & 0.00 \mathrm{E}+\infty & 3.04 \mathrm{E}-02 & 3.04 \mathrm{E}-01 & 3.04 \mathrm{E}+00 & 3.04 \mathrm{E}+00 & 3.04 \mathrm{E}+00\end{array}$

$\begin{array}{llllllllll}6 & 0.00 \mathrm{E}+\infty & 0.00 \mathrm{E}+\infty & 1.45 \mathrm{E}-02 & 1.45 \mathrm{E}-01 & 1.45 \mathrm{E}+\infty & 1.45 \mathrm{E}+\infty & 1.45 \mathrm{E}+\infty\end{array}$

$7 \quad 0.00 \mathrm{E}+\infty \quad 0.00 \mathrm{E}+\infty \quad$ 5.51E-03 5.51E-02 5.51E-01 5.51E-01 5.51E-01

$8 \quad 0.00 E+\infty 0 \quad 0.00 E+\infty 0 \quad 2.61 E-03 \quad 2.61 E-02 \quad 2.61 E-01 \quad 2.61 E-01 \quad 2.61 E-01$

$9 \quad 0.00 \mathrm{E}+\infty 0 \quad 0.00 \mathrm{E}+\infty \quad 1.21 \mathrm{E}-03 \quad 1.21 \mathrm{E}-02 \quad 1.21 \mathrm{E}-01 \quad 1.21 \mathrm{E}-01 \quad 1.21 \mathrm{E}-01$

$10 \quad 0.00 \mathrm{E}+00 \quad 0.00 \mathrm{E}+00 \quad 4.58 \mathrm{E}-04 \quad 4.58 \mathrm{E}-03 \quad 4.58 \mathrm{E}-02 \quad 4.58 \mathrm{E}-02 \quad 4.58 \mathrm{E}-02$

$11 \quad 0.00 \mathrm{E}+\infty \quad 0.00 \mathrm{E}+00 \quad 2.09 \mathrm{E}-04 \quad 2.09 \mathrm{E}-03 \quad 2.09 \mathrm{E}-02 \quad 2.09 \mathrm{E}-02 \quad 2.09 \mathrm{E}-02$

$12 \quad 0.00 \mathrm{E}+\infty 00.00 \mathrm{E}+\infty 0$ 9.91E-05 9.91E-04 9.91E-03 $9.91 \mathrm{E}-03 \quad 9.91 \mathrm{E}-03$

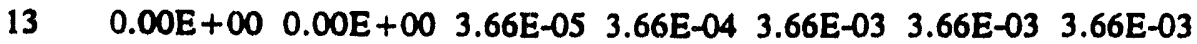

$14 \quad 0.00 \mathrm{E}+00 \quad 0.00 \mathrm{E}+00 \quad 1.73 \mathrm{E}-05 \quad 1.73 \mathrm{E}-04 \quad 1.73 \mathrm{E}-03 \quad 1.73 \mathrm{E}-03 \quad 1.73 \mathrm{E}-03$

$15 \quad 0.00 \mathrm{E}+00 \quad 0.00 \mathrm{E}+00 \quad 7.89 \mathrm{E}-06 \quad 7.89 \mathrm{E}-05 \quad 7.89 \mathrm{E}-04 \quad 7.89 \mathrm{E}-04 \quad 7.89 \mathrm{E}-04$

$16 \quad 0.00 \mathrm{E}+00 \quad 0.00 \mathrm{E}+00 \quad 4.21 \mathrm{E}-06$ 4.21E-05 4.21E-04 4.21E-04 4.21E-04

$17 \quad 0.00 \mathrm{E}+00 \quad 0.00 \mathrm{E}+00 \quad 2.57 \mathrm{E}-06 \quad 2.57 \mathrm{E}-05$ 2.57E-04 2.57E-04 2.57E-04

$18 \quad 0.00 \mathrm{E}+00 \quad 0.00 \mathrm{E}+00 \quad 1.68 \mathrm{E}-06 \quad 1.68 \mathrm{E}-05 \quad 1.68 \mathrm{E}-04 \quad 1.68 \mathrm{E}-04 \quad 1.68 \mathrm{E}-04$
} 


$\begin{array}{cc}\text { AREA } & \text { SEVER: } \\ 1 & 6.73 E+01 \\ 2 & 3.38 E+01 \\ 3 & 1.64 E+01 \\ 4 & 6.35 E+00 \\ 5 & 3.04 E+00 \\ 6 & 1.45 E+00 \\ 7 & 5.51 E-01 \\ 8 & 2.61 E-01 \\ 9 & 1.21 E-01 \\ 10 & 4.58 E-02 \\ 11 & 2.09 E-02 \\ 12 & 9.91 E-03 \\ 13 & 3.66 E-03 \\ 14 & 1.73 E-03 \\ 15 & 7.89 E-04 \\ 16 & 4.21 E-04 \\ 17 & 2.57 E-04 \\ 18 & 1.68 E-04\end{array}$

MODE TRUCK

\section{GROUND SURFACE CONTAMINATION TABLE (MICRO CI/M**2) BEFORE CLEANUP}

\footnotetext{
AREA \# SEVER: 1 SEVER: 2 SEVER: 3 SEVER: 4 SEVER: 5 SEVER: 6 SEVER: 7

$1 \quad 0.00 \mathrm{E}+00 \quad 0.00 \mathrm{E}+00 \quad 3.71 \mathrm{E}+03 \quad 3.71 \mathrm{E}+04 \quad 3.71 \mathrm{E}+05 \quad 3.71 \mathrm{E}+05 \quad 3.71 \mathrm{E}+05$ $0.00 \mathrm{E}+00 \quad 0.00 \mathrm{E}+00 \quad 1.86 \mathrm{E}+03 \quad 1.86 \mathrm{E}+04 \quad 1.86 \mathrm{E}+05 \quad 1.86 \mathrm{E}+05 \quad 1.86 \mathrm{E}+05$ $0.00 \mathrm{E}+00 \quad 0.00 \mathrm{E}+00 \quad 9.04 \mathrm{E}+02 \quad 9.04 \mathrm{E}+03 \quad 9.04 \mathrm{E}+04 \quad 9.04 \mathrm{E}+04 \quad 9.04 \mathrm{E}+04$ $0.00 \mathrm{E}+00 \quad 0.00 \mathrm{E}+00 \quad 3.50 \mathrm{E}+02 \quad 3.50 \mathrm{E}+03 \quad 3.50 \mathrm{E}+04 \quad 3.50 \mathrm{E}+04 \quad 3.50 \mathrm{E}+04$ $\begin{array}{lllllll}0.00 \mathrm{E}+00 & 0.00 \mathrm{E}+00 & 1.68 \mathrm{E}+02 & 1.68 \mathrm{E}+03 & 1.68 \mathrm{E}+04 & 1.68 \mathrm{E}+04 & 1.68 \mathrm{E}+04\end{array}$ $0.00 \mathrm{E}+00 \quad 0.00 \mathrm{E}+00 \quad 7.99 \mathrm{E}+01 \quad 7.99 \mathrm{E}+02 \quad 7.99 \mathrm{E}+03 \quad 7.99 \mathrm{E}+03 \quad 7.99 \mathrm{E}+03$ $0.00 \mathrm{E}+00 \quad 0.00 \mathrm{E}+00 \quad 3.03 \mathrm{E}+01 \quad 3.03 \mathrm{E}+02 \quad 3.03 \mathrm{E}+03 \quad 3.03 \mathrm{E}+03 \quad 3.03 \mathrm{E}+03$ $\begin{array}{lllllll}0.00 \mathrm{E}+00 & 0.00 \mathrm{E}+00 & 1.44 \mathrm{E}+01 & 1.44 \mathrm{E}+02 & 1.44 \mathrm{E}+03 & 1.44 \mathrm{E}+03 & 1.44 \mathrm{E}+03\end{array}$ $0.00 \mathrm{E}+00 \quad 0.00 \mathrm{E}+00 \quad 6.68 \mathrm{E}+00 \quad 6.68 \mathrm{E}+01 \quad 6.68 \mathrm{E}+02 \quad 6.68 \mathrm{E}+02 \quad 6.68 \mathrm{E}+02$ $0.00 \mathrm{E}+00 \quad 0.00 \mathrm{E}+\infty \quad 2.52 \mathrm{E}+00 \quad 2.52 \mathrm{E}+01 \quad 2.52 \mathrm{E}+02 \quad 2.52 \mathrm{E}+02 \quad 2.52 \mathrm{E}+02$ $0.00 \mathrm{E}+\infty 00.00 \mathrm{E}+\infty \quad 1.15 \mathrm{E}+00 \quad 1.15 \mathrm{E}+01 \quad 1.15 \mathrm{E}+02 \quad 1.15 \mathrm{E}+02 \quad 1.15 \mathrm{E}+02$ $0.00 \mathrm{E}+\infty 00.00 \mathrm{E}+00 \quad 5.46 \mathrm{E}-01 \quad 5.46 \mathrm{E}+00 \quad 5.46 \mathrm{E}+01 \quad 5.46 \mathrm{E}+01 \quad 5.46 \mathrm{E}+01$ $0.00 \mathrm{E}+00 \quad 0.00 \mathrm{E}+\infty 002.02 \mathrm{E}-01 \quad 2.02 \mathrm{E}+00 \quad 2.02 \mathrm{E}+01 \quad 2.02 \mathrm{E}+01 \quad 2.02 \mathrm{E}+01$

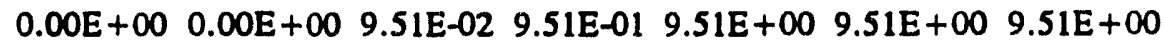

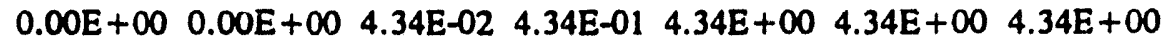
$0.00 \mathrm{E}+\infty 00.00 \mathrm{E}+\infty \quad 2.32 \mathrm{E}-02 \quad 2.32 \mathrm{E}-01 \quad 2.32 \mathrm{E}+\infty \quad 2.32 \mathrm{E}+\infty \quad 2.32 \mathrm{E}+\infty$

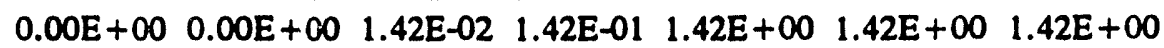
$0.00 \mathrm{E}+\infty 0 \quad 0.00 \mathrm{E}+00 \quad 9.26 \mathrm{E}-03 \quad 9.26 \mathrm{E}-02 \quad 9.26 \mathrm{E}-01 \quad 9.26 \mathrm{E}-01 \quad 9.26 \mathrm{E}-01$
} 


$\begin{array}{cc}\text { AREA \# } & \text { SEVER: } 8 \\ 1 & 3.71 \mathrm{E}+05 \\ 2 & 1.86 \mathrm{E}+05 \\ 3 & 9.04 \mathrm{E}+04 \\ 4 & 3.50 \mathrm{E}+04 \\ 5 & 1.68 \mathrm{E}+04 \\ 6 & 7.99 \mathrm{E}+03 \\ 7 & 3.03 \mathrm{E}+03 \\ 8 & 1.44 \mathrm{E}+03 \\ 9 & 6.68 \mathrm{E}+02 \\ 10 & 2.52 \mathrm{E}+02 \\ 11 & 1.15 \mathrm{E}+02 \\ 12 & 5.46 \mathrm{E}+01 \\ 13 & 2.02 \mathrm{E}+01 \\ 14 & 9.51 \mathrm{E}+00 \\ 15 & 4.34 \mathrm{E}+00 \\ 16 & 2.32 \mathrm{E}+00 \\ 11 & 1.42 \mathrm{E}+00 \\ 18 & 9.26 \mathrm{E}-01\end{array}$

INCIIENT-FREE SUMMARY

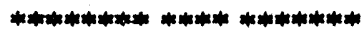

INCIDENT-FREE POPULATION EXPOSURE IN PERSON-REM

PASSENGR CREW HANDLERS OFF LINK ON LINK STOPS STORAGE TOTALS LINK 1 $0.00 \mathrm{E}+\infty 0$ 5.19E-01 0.00E + 00 1.50E- -2 8.12E-02 5.16E-01 0.00E + $001.13 \mathrm{E}+\infty 0$

TOTALS: $0.00 \mathrm{E}+00$ 5.19E-01 $0.00 \mathrm{E}+\infty 01.50 \mathrm{E}-02 \quad 8.12 \mathrm{E}-02$ 5.16E-01 $0.00 \mathrm{E}+001.13 \mathrm{E}+\infty$

MAXIMUM INDIVIDUAL IN-TRANSIT DOSE

LINK 1 6.97E-07 REM 
INDEX DESCRIPTION OF PARAMETER IMPORTANCE

1 DOSE RATE (TRANSPORT INDEX)

2 NUMBER OF SHIPMENTS

3 K ZERO

$1.131 \mathrm{E}-02$

4 PACKAGES PER SHIPMENT 1.131E-02

5 DISTANCE TRAVELED

6 NUMBER OF CREW MEMBERS

$131 E-02$

7 PERSONS EXPOSED WHILE STOPPED

5. $194 \mathrm{E}-03$

8 STOP TIME

$5.156 \mathrm{E}-03$

9 FRACTION OF TRAVEL - RURAL

5.156E-03

10 FRACTION OF TRAVEL - SUBURBAN

11 NUMBER OF PEOPLE PER VEHICLE

12 FRACTION OF TRAVEL - URBAN

3.681E-03

13 TRAFFIC COUNT - SUBURBAN

14 TRAFFIC COUNT - RURAL

$1.834 \mathrm{E}-03$

8.121E-04

15 FRACTION OF RUSH HOUR TRAVEL

16 TRAFFIC COUNT - URBAN

6.417E-04

3.727E-04

2.549E-04

17 FRACTION OF TRAVEL ON CITY STREETS 1.378E-04

18 POPULATION DENSITY - SUBURBAN 1.261E-04

19 SUBURBAN SHIELDING FACTOR (RS)

20 RATIO OF PEDESTRIAN DENSITY (RPD)

21 POPULATION DENSITY - URBAN

$1.153 E-04$

22 POPULATION DENSITY - RURAL

2.795E-05

23 RURAL SHIELDING FACTOR (RR)

24 URBAN SHIELDING FACTOR (RU)

25 HANDLER EXPOSURE DISTANCE

$1.929 E-05$

4.567E-06

4.357E-06

2.340E-06

$0.000 \mathrm{E}+00$

26 NUMBER OF PERSONS EXPOSED DURING STO
27 NUMBER OF FLIGHT ATTENDANTS

28 PERSONS EXPOSED PER HANDLING

29 EXPOSURE TIME FOR HANDLERS

30 STORAGE EXPOSURE DISTANCE

31 NUMBER OF HANDLINGS

32 STORAGE TIME PER SHIPMENT

33 VELOCITY - URBAN

$0.000 E+00$

$0.000 \mathrm{E}+00$

$0.000 \mathrm{E}+00$

$0.000 \mathrm{E}+00$

$0.000 \mathrm{E}+\infty 0$

$0.000 \mathrm{E}+00$

34 FRACTION OF TRAVEL ON FREEWAYS -1.191E-03

35 VELOCITY - SUBURBAN $\quad-2.004 E-03$

36 DISTANCE FROM SOURCE TO CREW $-2.138 E-03$

37 VELOCITY - RURAL

$-4.262 E-03$

38 EXPOSURE DISTANCE WHILE STOPPED -1.031E-02

THE IMPORTANCE VALUE ESTIMATES THE PERSON-REM INFLUENCE

OF A ONE PERCENT INCREASE IN THE PARAMETER 
NUMBER OF EXPECTED ACCIDENTS - MODE TRUCK

\begin{tabular}{cccc} 
CATEGORY & RURAL & \multicolumn{2}{c}{ SUBURB } \\
1 & $5.22 \mathrm{E}-04$ & $1.91 \mathrm{E}-03$ & $2.69 \mathrm{E}-03$ \\
2 & $3.41 \mathrm{E}-04$ & $1.25 \mathrm{E}-03$ & $1.76 \mathrm{E}-03$ \\
3 & $1.99 \mathrm{E}-04$ & $9.71 \mathrm{E}-04$ & $1.28 \mathrm{E}-04$ \\
4 & $4.55 \mathrm{E}-05$ & $2.22 \mathrm{E}-04$ & $2.93 \mathrm{E}-05$ \\
5 & $1.33 \mathrm{E}-05$ & $2.92 \mathrm{E}-05$ & $3.42 \mathrm{E}-06$ \\
6 & $7.31 \mathrm{E}-06$ & $7.65 \mathrm{E}-06$ & $6.73 \mathrm{E}-07$ \\
7 & $6.45 \mathrm{E}-07$ & $2.95 \mathrm{E}-07$ & $5.21 \mathrm{E}-08$ \\
8 & $1.28 \mathrm{E}-07$ & $2.61 \mathrm{E}-08$ & $4.58 \mathrm{E}-09$
\end{tabular}

EARLY FATALITY CONSEQUENCES - MODE TRUCK

$\begin{array}{cccc}\text { CATEGORY } & \text { RURAL } & \text { SUBURB } & \text { URBAN } \\ 1 & 0.00 \mathrm{E}+\infty & 0.00 \mathrm{E}+\infty & 0.00 \mathrm{E}+\infty \\ 2 & 0.00 \mathrm{E}+\infty & 0.00 \mathrm{E}+\infty & 0.00 \mathrm{E}+\infty \\ 3 & 0.00 \mathrm{E}+\infty & 0.00 \mathrm{E}+\infty & 0.00 \mathrm{E}+\infty \\ 4 & 0.00 \mathrm{E}+\infty & 0.00 \mathrm{E}+\infty & 0.00 \mathrm{E}+\infty \\ 5 & 0.00 \mathrm{E}+\infty & 0.00 \mathrm{E}+\infty & 0.00 \mathrm{E}+\infty \\ 6 & 0.00 \mathrm{E}+\infty & 0.00 \mathrm{E}+\infty & 0.00 \mathrm{E}+\infty \\ 7 & 0.00 \mathrm{E}+\infty & 0.00 \mathrm{E}+\infty & 0.00 \mathrm{E}+\infty \\ 8 & 0.00 \mathrm{E}+\infty & 0.00 \mathrm{E}+\infty & 0.00 \mathrm{E}+\infty\end{array}$

ECONOMIC CONSEQUENC'SS - MODE TRUCK

$\begin{array}{cc}\text { CATEGORY } & \text { RURAL } \\ 1 & 0.00 \mathrm{E}+\infty 0 \\ 2 & 0.00 \mathrm{E}+\infty 0 \\ 3 & 0.00 \mathrm{E}+\infty 0 \\ 4 & 0.00 \mathrm{E}+\infty 0 \\ 5 & 0.00 \mathrm{E}+\infty \\ 6 & 0.00 \mathrm{E}+\infty \\ 7 & 0.00 \mathrm{E}+\infty \\ 8 & 0.00 \mathrm{E}+\infty\end{array}$

$\quad$ SJBURB
$0.00 E+\infty$
$0.00 E+\infty$
$0.00 E+\infty 0$
$0.00 E+\infty$
$0.00 E+\infty$
$0.00 E+\infty$
$0.00 E+\infty$
$0.00 E+\infty$

URBAN

$0.00 E+\infty 0$

$0.00 E+00$

$0.00 E+00$

$0.00 E+\infty 0$

$0.00 \mathrm{E}+\infty 0$

$0.00 E+00$

$0.00 E+\infty 0$

$0.00 \mathrm{E}+\infty 0$ 


\begin{tabular}{|c|c|c|c|}
\hline & \multicolumn{3}{|c|}{$\begin{array}{l}\text { RADIOLOGICAL CONSEQUENCES - MODE TRUCK } \\
50 \text { YEAR POPULATION DOSE IN PERSON REM }\end{array}$} \\
\hline CAT & RY RURAL & SUBURB & URBAN \\
\hline 1 & $0.00 E+\infty 0$ & $0.00 \mathrm{E}+\infty$ & $0.00 E+\infty$ \\
\hline 2 & $0.00 E+\infty 0$ & $0.00 E+00$ & $0.00 E+\infty 0$ \\
\hline 3 & $2.35 E+02$ & $2.82 E+04$ & $9.15 E+04$ \\
\hline 4 & $2.35 E+03$ & $2.82 E+05$ & $9.15 E+05$ \\
\hline 5 & $2.35 E+04$ & $2.82 E+06$ & $9.14 E+06$ \\
\hline 6 & $2.35 \mathrm{E}+04$ & $2.82 E+06$ & $9.14 E+06$ \\
\hline 7 & $2.35 E+04$ & $2.82 E+\infty 6$ & $9.14 E+06$ \\
\hline 8 & $2.35 E+04$ & $2.82 E+06$ & $9.14 E+06$ \\
\hline
\end{tabular}
PUO2

EXPECTED VALUES OF POPULATION RISK IN PERSON REM

PU239 9.44E-02 3.95E +01 1.80E +02 5.46E-07 0.00E + $00 \quad 2.20 \mathrm{E}+02$

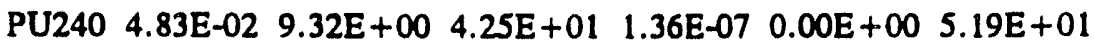

TOTALS: $1.43 \mathrm{E}-01 \quad 4.88 \mathrm{E}+01 \quad 2.23 \mathrm{E}+02 \quad 6.82 \mathrm{E}-07 \quad 0.00 \mathrm{E}+00 \quad 2.72 \mathrm{E}+02$

* NOTE THAT INGESTION RISK IS A SOCIETAL RISK;

THE USER MAY WISH TO TREAT THIS VALUE SEPARATELY.

EXPECTED RISK VALUES - OTHER

LINK ECON EARLY

SS FATALITY

$1 \quad 0.00 E+\infty \quad 0.00 E+\infty$

TOTAL $\quad 0.00 \mathrm{E}+00 \quad 0.00 \mathrm{E}+00$

EOI

END OF RUN 


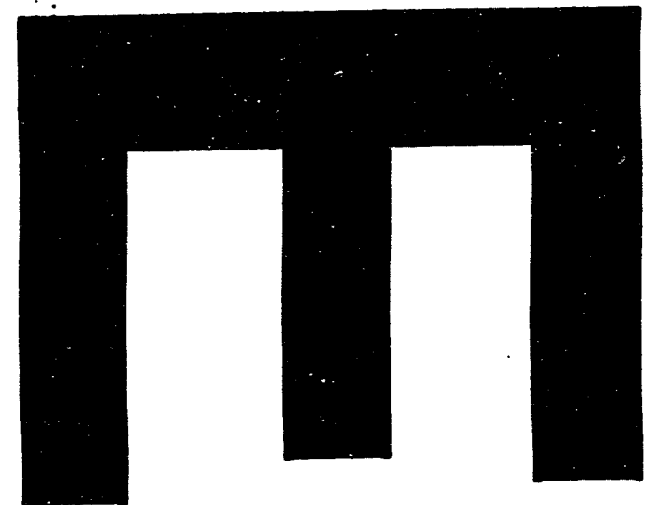

L
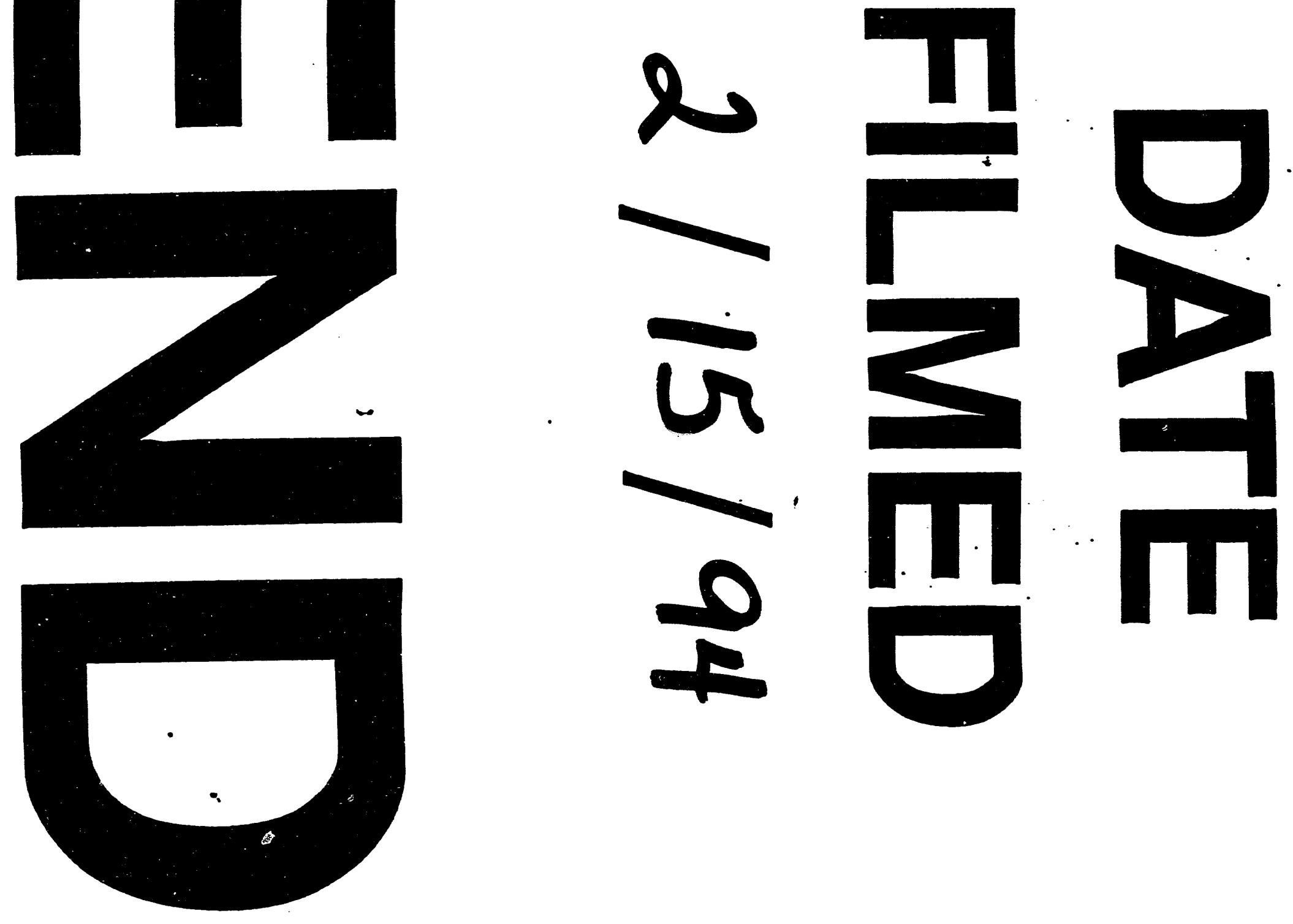
